3EASDTHE

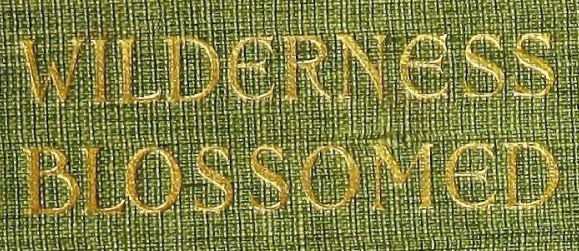

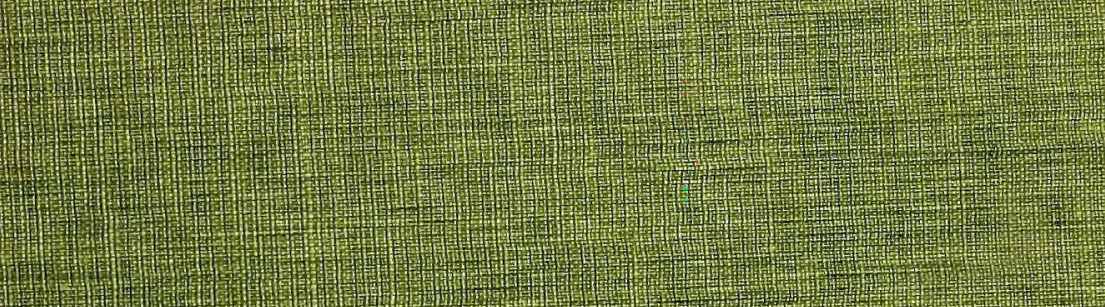

H.

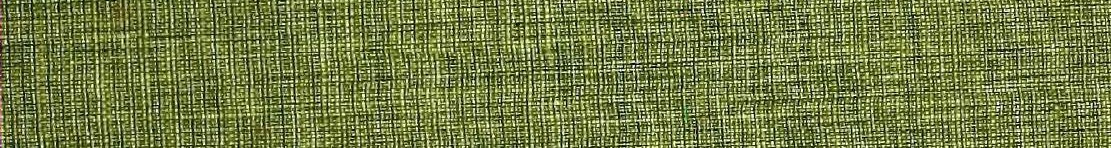

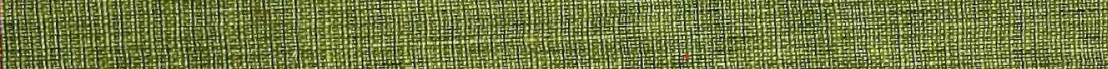

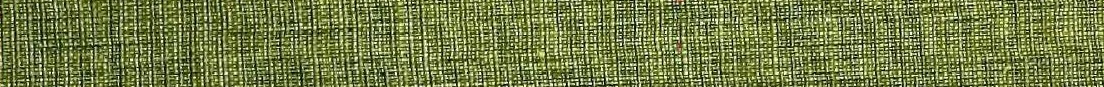

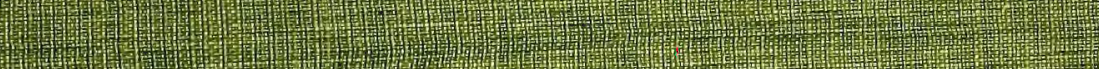

Hat

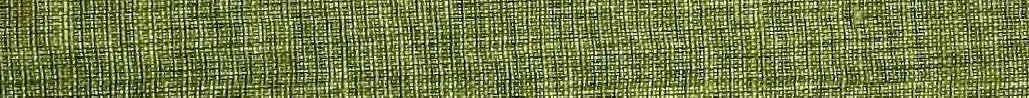

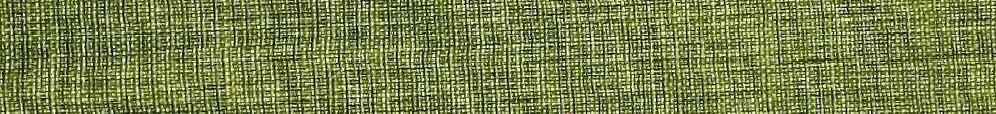

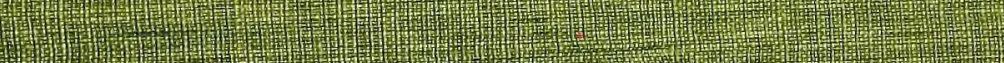

m (3)

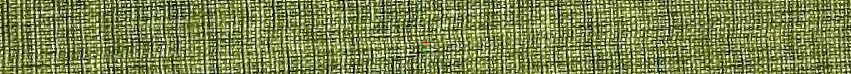

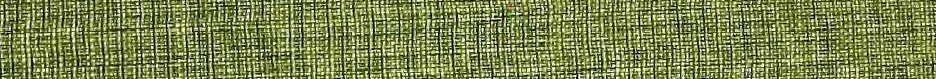

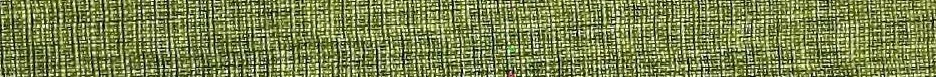

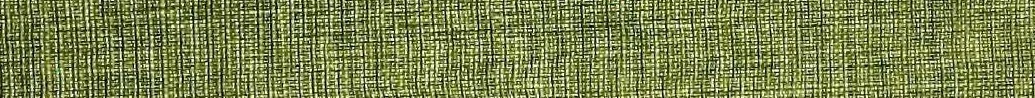
thes bexert 


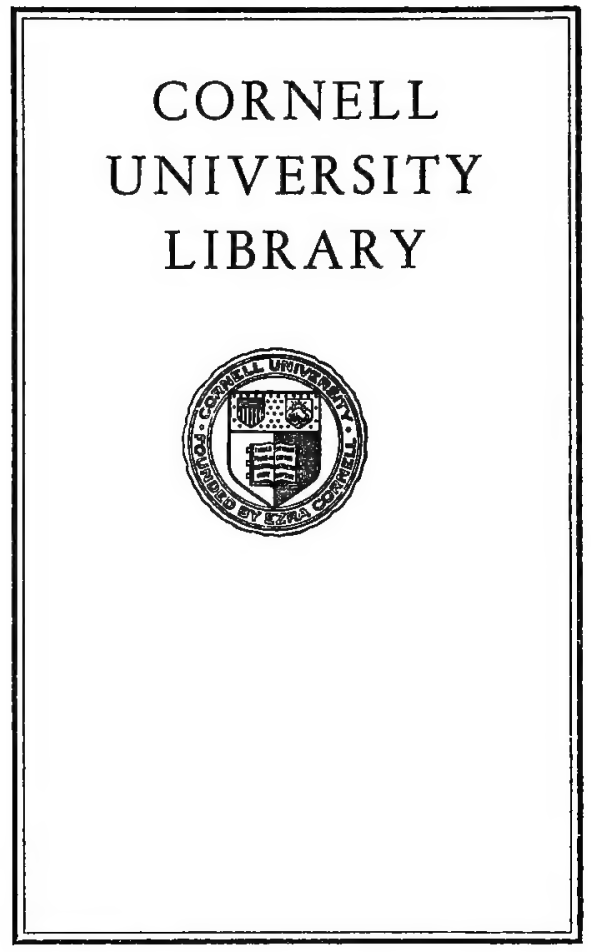




\section{SB 453.D55}

Cornell University Library

And the wilderness blossomed,

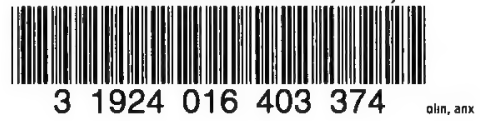




\section{Cornell University Library}

The original of this book is in the Cornell University Library.

There are no known copyright restrictions in the United States on the use of the text. 
And the Wilderness Blossomed 




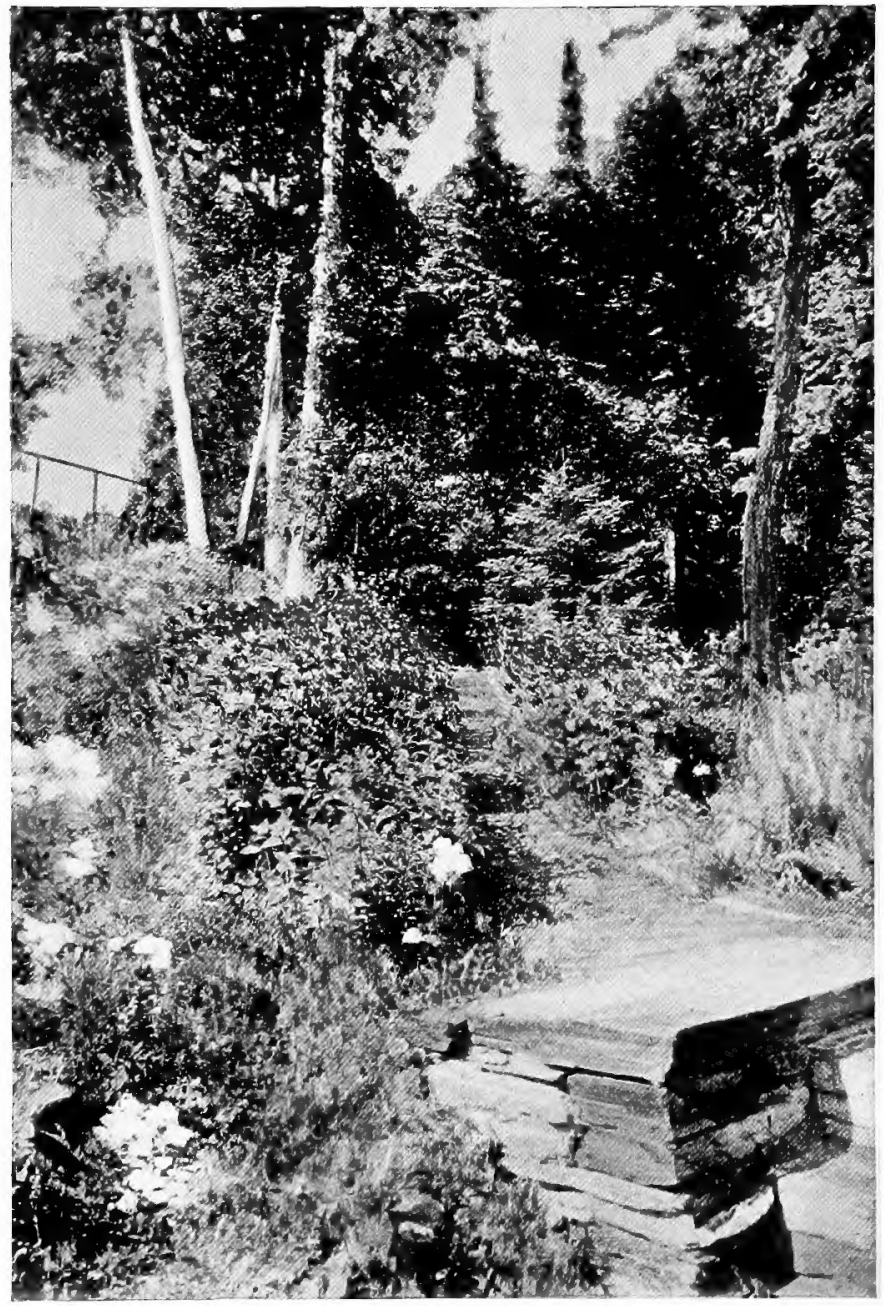

A CORNER OF THE TERRACE 
And the Wilderness

Blossomed

\author{
By \\ Almon Dexter
}

to

\title{
Philadelphia
}

H. W. Fisher E Company

I 90 I 
Copyright, roor,

By H. W. Fisher \& Company

All rights reserved

UNIVERSITY PRESS - JOHN WILSON

AND SON - CAMBRIDGE, U.S.A. 


\section{FERDINAND W. ROEBLING,}

And the others who have been there.

How many goodly creatures are there here! How beauteous mankind is! O brave new world, That has such people in 't!

Tempest, v. I. 



\section{CONTENTS}

CHAPTER I

PAGE

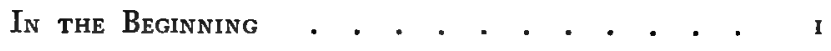

\section{CHAPTER II}

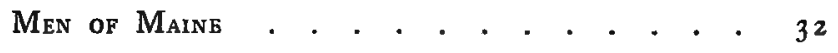

CHAPTER III

The Vestrbule . . . . . . . . . . . . 6 I

CHAPTER IV

Some Birds . . . . . . . . . . . . . . 89

CHAPTER V

Flower Beds . . . . . . . . . . . . 120

CHAPTER VI

Perennials and Biennials . . . . . . . . . . 13 I 


\section{CONTENTS}

CHAPTER VII

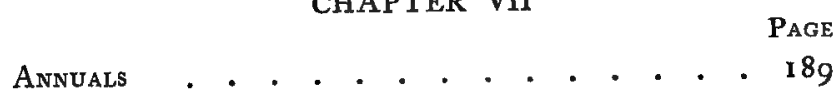

CHAPTER VIII

SEEDS . . . . . . . . . . . . . . 246

Postscript . . . . . . . . . . . . . 272 


\section{ILLUSTRATIONS}

PAGE

A Corner of the Terrace . . . . . . . Frontispiece The Outside as It Hafpened . . . . . . . . 7 The Fireplace . . . . . . . . . . . . . II The Hallway . . . . . . . . . . . . 15 Trees and Lawn . • • • . . . . . . . 24 A Burglar-Proof Safe . . . . . . . . . 36 The Garden Beds. . . . . . . . . . . . 98 The Professor's CARd . . . . . . . . . 105 The Terrace Wall . . . . . . . . . . I 26 Digitalis, the Blossom . . . . . . . . 138 A Clump of Foxglove . . . . . . . . . . I 39 Lupines and Oriental Poppies . . . . . . 168 Callirhoe Involucrata . . . . . . . . . 177 The Bride PopPy . . . . . . . . . . . . I 92 The Larkspur . . . . . . . . . . . 215 The Forest Primeval . . . . . . . . . 240 



\section{And the Wilderness Blossomed}

\section{CHAPTER I}

IN THE BEGINNING

"Tbis is the bouse that Fack built."

"T DON'T see why you talk so much about building a camp at Winnebago," said Hortense, looking up seriously from her needlework, in reply to some observation of mine on the joys of a lodge in the wilderness. "You know I could not take the children in there; the flies and the mosquitoes would simply eat them up alive. Now, if you would buy that island we see on passing Insley Lake and build a comfortable house on it, I'd take the children there and stay all summer."

"You would!" I exclaimed, and rising from my chair went at once to my desk, and sitting down wrote to my friend Leaf, who had been going fishing in the Insley region for no end of years and knew everybody and everything there. I asked him if he knew anything about this 


\section{AND THE WILDERNESS BLOSSOMED}

island, who owned it, and whether it could be bought. Now, there is no dearer fellow in the world than Theodore Leaf, and he was not only able to answer all my questions satisfactorily, but actually offered to go and see the owners, who lived in Massachusetts, and buy the property in my behalf; and he did it too, and in a brief time the island of Norinamentook was mine, or rather it was the property of Hortense, and the deeds, with careful folding, went into her stocking the following Christmas eve. Deeds for real estate in Maine are very small.

Talking once with a Maine man about a wharf that had lately been built in an exposed situation on the lake, he remarked that it was "a terrible hard chance over there," and I think it was "a terrible hard chance" I had undertaken when I proposed to build this comfortable house on an island covered with primeval forest, nearly twenty-five miles from a railroad, and which I had only seen from a distance of two miles across the water. Nevertheless, I resolved to take the chance and see what would come of it.

In a way, its very remoteness and wildness was an attraction. I had nature to contend with, to be sure, but I was quite free from the machina- 


\section{IN THE BEGINNING}

tions of man ; I would have none of his blunders to correct. It was all fresh, new, inspiring.

At the outset there is a word to be said as to the locality we had chosen. Insley Lake is the head of a chain of lakes in the State of Maine, at a distance of about twenty miles from the town of Firmins, where a railroad connects the town with the outer world. The stage road, though hilly, is a good solid highway, and in clear weather the drive is an agreeable one, but generally it showers when you drive in or out. Insley Lake is about ten miles long, running nearly east and west. On the eastern shore is the village of Insley; then a small collection of houses with a hotel, a general store, a blacksmith shop, two sawmills, a school, and a church. The island contains about twenty acres, densely covered with forest, and is about two miles from the eastern end of the lake. Near the western end is another island known as Megwamantic, quite as wild as its sister isle. On the north shore is Neseghigo Cove, and on the western point of the cove there was at the time I bought the island a small cottage occupied in the summer months by a Dr. Bringhurst from Connecticut. The eastern end of the lake, a portion of the 


\section{AND THE WILDERNESS BLOSSOMED}

northern shore, and a still smaller portion of the southern shore had been partially cleared of timber, and thrifty-looking farm-houses dotted the green slopes. The small hotel in the village was frequented by travelling anglers in the summer months, and almost buried under snow in the winter. Near the western end, at the lake's outlet, was still another small hotel, and near by was a club-house owned by Boston anglers. Both these hotels were well filled in summer, for the fame of trout-fishing in Insley Lake was widespread, and indeed it was the excellence of the fishing that first turned my steps to this part of Maine, and on more than one occasion I had brought wife and children with me. Since starting to build my house, I regret to say, I have never had time to go a-fishing, so the reader need not look here for any accounts of great catches of big trout.

Insley Lake, named after an early settler, had been known to the Indians as Nikowussoc. Beyond its eastern border rises the highest mountain in this part of Maine, Keespennadengog. A little further north is a smaller conical peak known as Penakadensis, while parallel to the north shore of the lake is a long ridge whose 


\section{IN THE BEGINNING}

curiously marked side probably induced the Indians to name it Psagatsitag. Beyond this latter mountain lies another beautiful sheet of water, Winnebago, on whose shores I had once longed to build my camp. At the western end of Insley Lake rises a beautiful peak known as Moosiwadchet. The waters of this lake, after passing through the other lakes of the chain, form the well-known Nameskowhegan River, so important to the manufacturing interests of the State at Fryeburg and other points.

The region is a very beautiful one, and at an altitude of about 1700 feet above sea-level one is sure of charming weather throughout the summer, - if anything, generally a little too cool, and absolutely perfect when the papers in Boston, New York, Philadelphia, and other cities are filled with stories of sunstroke and prostrations from the intense heat. Americans make annual pilgrimages to Switzerland, and rave over the beauty of its lake and mountain scenery, oblivious, apparently ignorant, of the fact that our own country furnishes every variety of the picturesque in the superlative degree, compared with anything that can be found in Europe.

Three strangers met one night in a small hotel 


\section{AND THE WILDERNESS BLOSSOMED}

in the West, and one was asked "where are you from?" Drawing himself up proudly, he replied, "I am from Virginia, the mother of Presidents, the home of chivalry ; and you ?"

"I," said the second, " am from Kentucky, the region of the blue grass, the home of the fast horse, of beautiful women, and of brave men; and," he asked, turning to the third, "where are you from ?"

"I," said the tall, spare man, "am from the garden spot of America."

"Indeed," exclaimed the others in a breath, "and where, pray, is that?"

"Podunk, Maine," was the complacent answer. "Kin 1 sell you a razor strop?"

One only appreciates this anecdote to the full when he knows Insley.

So much for the region in which we were to find a new home. The first consideration, of course, was our house; and from the start we had decided to build it ourselves, untrammelled by architects, landscape-gardeners, contractors, and the like useful but annoying artists, who are always so ready with reasons why this or that thing that you most want done cannot be done as you want it done. It always has seemed to 



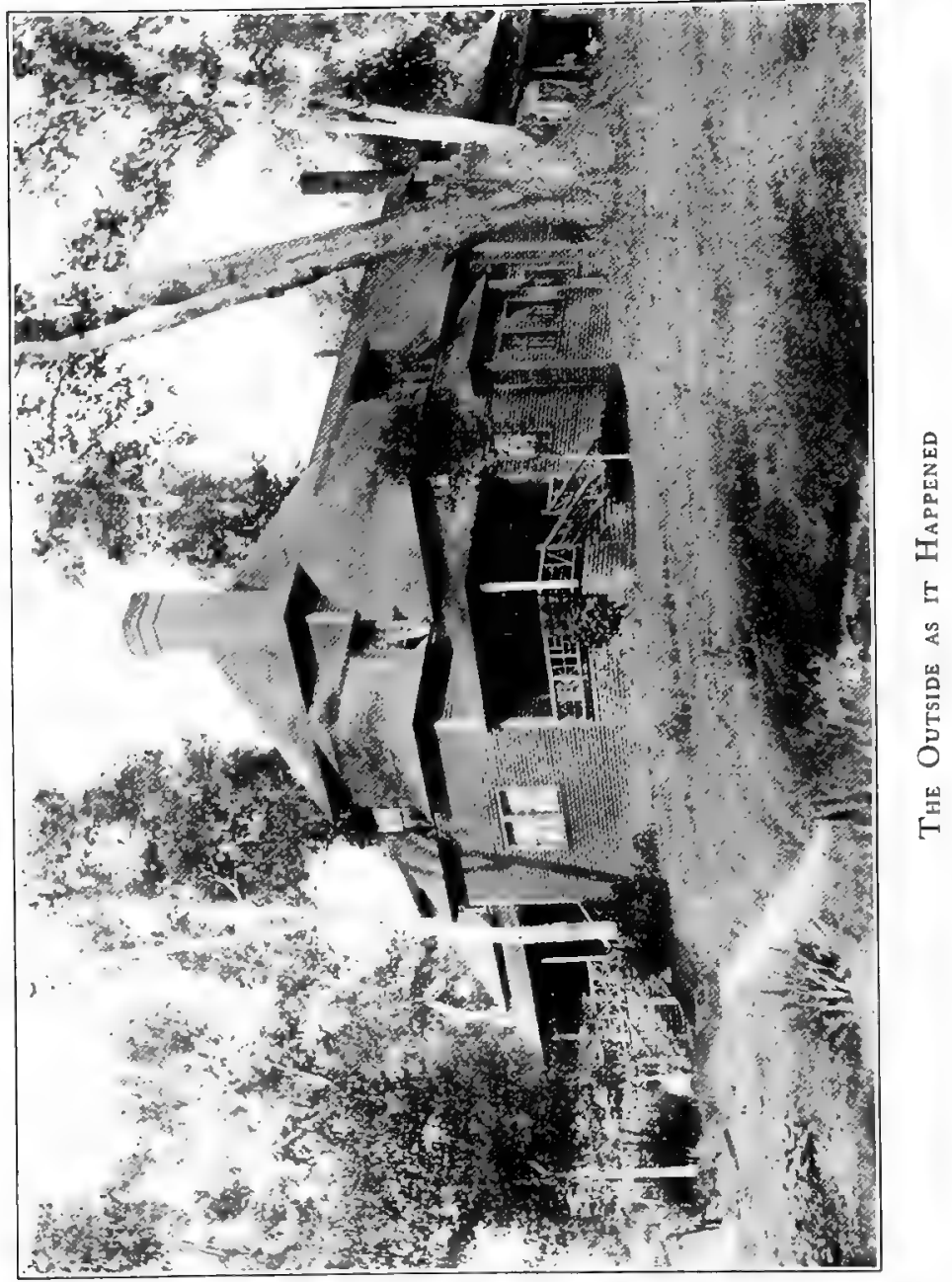




\section{IN THE BEGINNING}

me that architects, when they plan a house, think first of all, and most of all, of how it is going to look from the outside. Now the outside of a house is, after all, mainly for the benefit of the passer-by, while the owner lives on the inside, and very rarely takes the trouble to go outside to view his own building, and after a time scarcely glances at it when he is outside. Naturally we went to the other extreme, and never thought of the outside at all, but planned the inside so that it should be exactly suited to our needs, and the outside had to fit itself to our requirements. We planned each room separately, and then moved them around until we got them in just the place we wanted them. First of all came the hall, which was to be twenty feet square; then came two bedrooms, each being eighteen feet square; then a dining-room, $16 \times 20$, a bathroom, $6 \times 12$, a pantry, $7 \times 18$, a kitchen, $16 \times 18$; and these, with a laundry and woodshed, made up the first floor. The walls were to be built up but three feet above the second floor, and for the rest followed the slope of the square pitched roof. One thing we determined upon from the outset: the ceilings should all be the same height, so that if a picture was moved from 


\section{AND THE WILDERNESS BLOSSOMED}

one room to another the wire would not have to be altered. Architects delight in getting as many variations in the heights of their ceilings as there are rooms in the house. Sometimes this is difficult, but that only adds to the labors of the architect, and sometimes it is impossible, and then you will get two rooms of the same height, but not otherwise. We determined upon another innovation also. Each bedroom should have sufficient wall space for the head-board of a bed, and also space for a bureau, which should be near a window, or, if possible, between two windows; and we so arranged the dining-room that a sideboard might be placed against the wall without blocking up either a doorway or a window. Another oddity about this house was that the pantry was to be big enough to hold the china and glassware of an ordinary family and still give plenty of room for a maid, or two if need be, to wash this glass and china when necessary. In the ordinary modern house the parlor may be imposing, and the dining-room even generous in size, but when it comes to such items as the pantry, the bathrooms, the kitchen, the closets, and the like, rooms in which the work of living is carried on, architects begin to 


\section{IN THE BEGINNING}

economize space. Nowadays when one gets a new maid she has to be measured to see if she'll fit the pantry. A friend of mine had a maid who actually stuck fast in the back stairway and had to be pulled out by the heels. As they could not enlarge the stairway, she resigned, and her place was filled by a new maid two sizes smaller. I know of a palace built for a merchant prince in which the choicest bedroom had absolutely no vacant wall space for a bureau, the whole being occupied by an enormous circular window, beautiful to look at, especially from the outside, but of no utility at all in a bedroom. The architect was an artist, of course, or he never could have thought of such a window, so he was able to design a bureau for this particular room. It was practically two bureaus in one, with two mirrors back to back, and it was intended to rest in the centre of the circular window, the front of one side being square and the other circular, following the curve of the window. Windows ought to be put in a building for the purpose of giving light to the occupants, but they seem to be generally arranged for the purpose of making a building look artistic from the outside. The municipal building of a great city 


\section{AND THE WILDERNESS BLOSSOMED}

has cost more than the Taj Mahal, and there is hardly one room out of the hundreds that it contains in which business can be carried on even at midday without artificial light. If this building were beautiful, one might condone the entire absence of utility in the structure, but every day men of artistic temperament lean up against near-by trolley-poles and weep when they look at it. The mayor has lately ordered the police to compel these people to move on, as they obstruct traffic.

Of course in a summer home one must have fireplaces, and fireplaces are of little utility if the smoke escapes into the room instead of going up the chimney. A fire of coals in a grate does not require much of a flue, but when you have a large opening in which you expect to burn great logs of wood, the size of your flue must be materially increased. A large stone fireplace was built in the lounging-room of a city club of which I happen to be a member, and though it cost a couple of thousand dollars, a fire was never built in it but once, and then all the smoke came out into the room, and the members went out of the doors. The architect had not apparently supplied any flue at all worth mentioning. For- 


\section{IN THE BEGINNING}

tunately for me, about this time I found an essay on chimneys and fireplaces, written a century or more ago by Count Rumford. As the Count

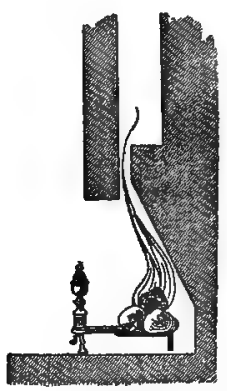

FIG. 1. knew nothing of coal as a fuel, the dimensions of his chimneys were based on the burning of wood, and made large enough for the purpose. The back of his fireplaces sloped forward, making a narrow opening for the smoke toward the front. This narrow opening extended up for a foot or more, and then dropped back square making a shoulder or shelf. If there is any back draught in such a chimney, the cold air strikes this shoulder and the hot air carries it up again at once, giving it no chance to get into the room and take the smoke with it. This little sketch (Fig. I) shows the method of construction. Three of our fireplaces were arranged together, back to back, with one

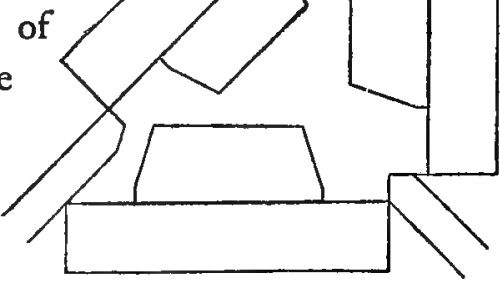

FIG. 2. 


\section{AND THE WILDERNESS BLOSSOMED}

chimney, but with separate flues. One, the largest, is in a corner of the hall, and next to it is also a corner fireplace in the dining-room, the third being on the side of an adjoining bedroom. This sketch (Fig. 2) explains it. An advantage of this arrangement is that there can be no wood-work behind any of these fireplaces and danger from fire is practically eliminated. None of the timbers of either of the floors or of the roof touch the chimney at all. There is a space between the wood and the brick-work everywhere.

Now and then you will find a stairway up which you can walk without appreciable effort. If you will stop and measure the steps on such a flight, you will find that the riser, or elevation of the steps, does not vary much from six inches in height, and that the tread, or width of the step, is about thirteen inches. The average man raises his foot about so high, and advances it each time about so far, and any variation from this compels him to call upon his muscles for extra work with resulting fatigue. It seems to me that this ought to be horn-book law to the architects, and that long ere this the proper dimensions of a staircase should have been ascertained and reduced to a positive law, to be followed wherever possible. 


\section{IN THE BEGINNING}

Yet how seldom it is that one finds a comfortable staircase, either in our private houses or in public buildings. Measure them, and you will find that the riser is generally from seven to eight inches, and the tread rarely much exceeds ten. In one of the largest of our railroad stations the architect designed the staircase, to be built of enduring stone, so steep that it was a daily occurrence for people to trip going up, or to fall headlong going down. The accidents were so frequent that the company was forced to build a wooden structure over the expensive stone work, with a proper rise and tread. For such a blunder as this there could be no excuse whatever. The architect had been doing work for the railroad company for years, and had probably designed thousands of staircases, giving him ample opportunity to learn the proper formula for such a structure, and in no event could want of space be urged as an excuse, as the building of the wooden superstructure subsequently proved. When this building was remodelled a few years ago, a new stone stairway was built which went, I think, a little too far to the other extreme, the risers being six inches high, and the treads fifteen and a half broad. While people neither stumble nor fall on 


\section{AND THE WILDERNESS BLOSSOMED}

this stairway, it is somewhat annoying in practical use, the average man being compelled to take a longer step than is natural or else now and then to take a double step on a single tread. Another frequent fault in stairways is in building them in curves, and nothing could well be more objectionable, it being necessary in such cases to step carefully on the outer edge of the circle at the constant risk of a dangerous fall. Yet such stairways are not only built in private houses, but also are frequently found in public buildings, where people often congregate in crowds. These winding staircases have before now become veritable deathtraps in burning theatres, and their use should be absolutely prohibited by law in any public building, and avoided persistently in any private house. In our dwellings the stairways are almost invariably too narrow, rarely exceeding three feet in width, and as a consequence the walls are marred every time a trunk or large piece of furniture is carried up or down. Three feet and a half should be insisted upon as the minimum width of a staircase in a private house, and four feet should be secured whenever possible, even if it be at the expense of the parlor.

There can be no prettier or more useful feature 



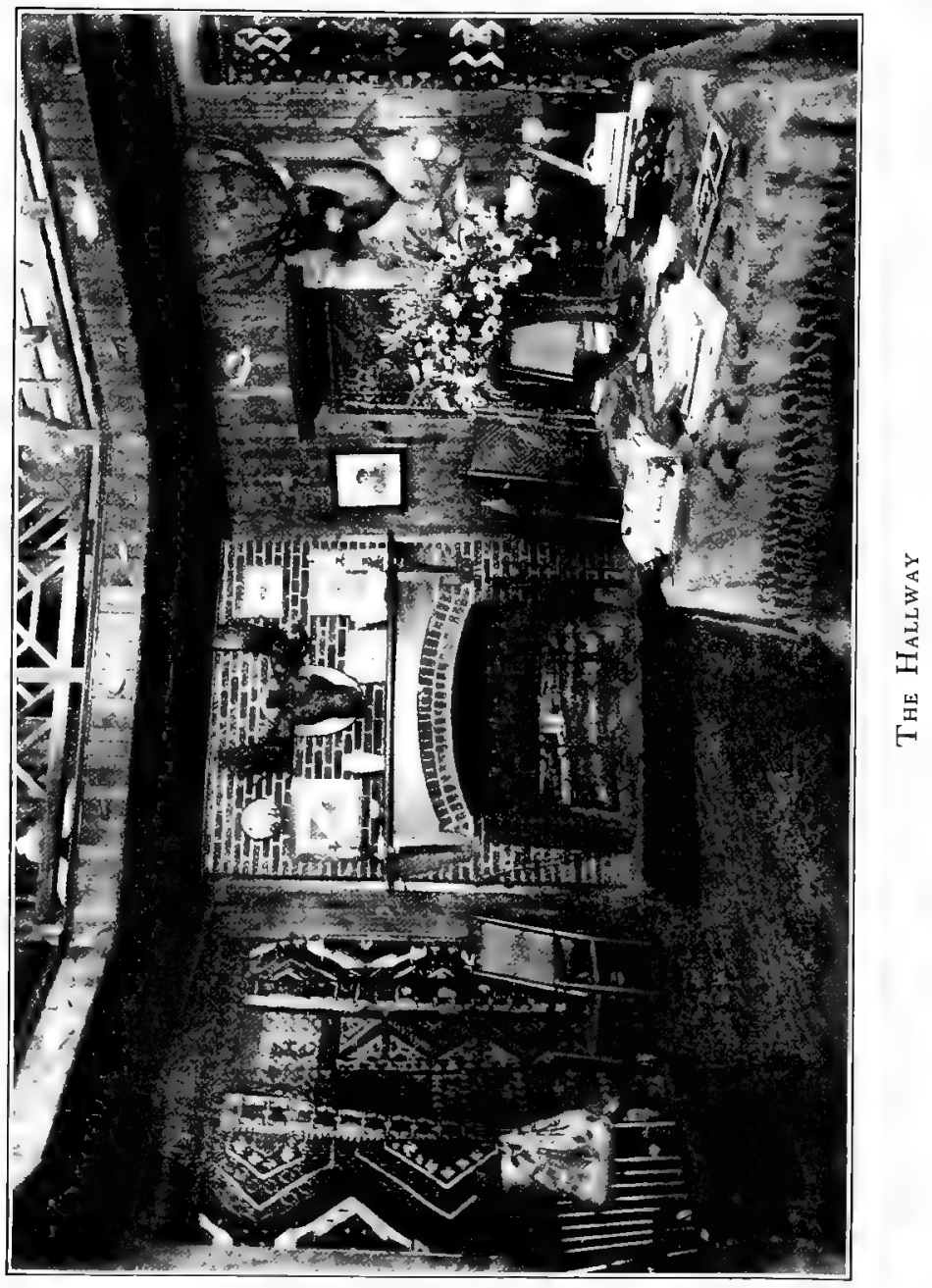




\section{IN THE BEGINNING}

in a summer home than a hallway two stories high, with a gallery running around the second floor, giving access to the several rooms. Such a room must always be comparatively cool and delightful in warm weather, and with a generous fireplace the ventilation is bound to be of the best. In such a room smoking may be indulged in freely without making the atmosphere disagreeable to those who do not indulge in tobacco.

I bought the timber for this house in the log, and had it sawed up at the mill in the village. The machinery available was not extensive, but they could plane, tongue, groove, and bead, and make a quarter round, or a scotia. With this help everything else was done on the island, the window-sash only being brought from a distance. The materials all came from the lake shore, and the men who built the house were at times carpenters, farmers, guides, or trappers. I have never seen anywhere a more intelligent, capable, and faithful body of men. I suppose I have had in past years, from time to time, more than a hundred different men in my employ, in all sorts of labor, often under exasperating conditions, and yet I have never heard an unkind or quarrelsome word spoken by one to another. 


\section{AND THE WILDERNESS BLOSSOMED}

Some of these men are superb mechanics, the old-fashioned kind, who not only know all branches of their own trade thoroughly, but also much of kindred trades. I brought with me the design of a corner closet to be built in the diningroom, copied after an antique model containing those little diamond panes of glass which are so attractive. I showed the plans to Charlie Barrett, and asked him if he could build it. "I think so," he said musingly; "I have n't any plane to work out those styles, but I guess I could do it." He did not appear at the island the next day, and I found out later that he had spent the time in a blacksmith shop making and tempering a plane to correspond with my drawing. That these people should be so skilful in the management of metals, with actually no training at all, is not less than marvellous to me. I have in my possession a steel hunting-knife of superior quality and finish, made by one of my Maine friends. The blade is worked out of an old file, and the maker had no forge but the kitchen stove; yet 1 am quite satisfied that I could not buy as good a knife in the trade centres of either America or Europe.

During our first summer one of my men came I6 


\section{IN THE BEGINNING}

to me and said: "Now look here. You're gettin' to have quite a lot of guests, and that makes quite a lot of slop, which you don't use, an' that 's waste. Now Jerry Oakes has got a hog that ain't fattenin' up as fast as he might, an' so Jerry wants to make a trade with you. He says he 'll weigh the hog now, an' then send him over to the island, an' you can feed him on the slop you 're wastin', and when you leave at the end of the season, we 'll weigh him again, send him back, and Jerry 'll pay you six cents for every pound he's gained. Ain't that a fair trade?" And the hog came and waxed fat, and the ingenious Yankee that engineered the "trade" got the profits for his perquisites, as he deserved; but that was the first and last hog that ever took up his residence on the island, the profit not being sufficient to induce us to crave the society of his kind again.

Generally we have brought our household servants with us, supplementing the number, when necessary, with people from the neighborhood. Every year this has grown more difficult, as from the increasing number of summer visitors there is more work to do in the village and possibly greater profit to be gained. Still, we have had 


\section{AND THE WILDERNESS BLOSSOMED}

some most capable people with us in the past. Viola was not to be excelled as a laundress, a waitress, or in general housework. She never had much to say, being fully occupied in doing. Once passing through the hall where she was sweeping, I noticed the rug was covered with some white substance, and therefore asked, "What is that on the rug, Viola?"

"Salt," was the laconic answer.

"Salt," I said. "Is that good for the rug?"

"It is," she responded; and the woman that can satisfactorily answer two questions with a total of three syllables is a jewel to be carefully treasured.

On another occasion I noticed an ugly brown spot on the lawn, a yard in diameter, near the laundry door, where shortly before had been only velvety green grass; and as Viola was the first person I met after seeing it, I asked, "Viola, do you know what killed the grass there?"

"Hot water," was her reply.

"Well, who," I demanded, "was fool enough to pour hot water on the grass ?"

"I was," she replied with perfect calmness.

Utterly disarmed, I could only weakly remark, "Well, I hope you won't do it again." 


\section{IN THE BEGINNING}

Her quiet "I won't" ended the interview. Solomon may have been wise for his age and generation, but he was not in the same class with Viola.

Additional help was needed in the laundry on one occasion, and Hortense found it after breakfast in a hammock on the laundry porch.

"So you have come to help us, have you ?" she asked; "and what is your name?"

"Miss Wilder," was the response, as she continued swinging. Her reign over the tubs was but a brief one.

Of course I am the mildest-mannered of men, and once when a nursemaid of pure Celtic extraction was leaving us, Hortense absolutely refused to give her a recommendation. Out of pure good nature (Hortense declares it was only want of conscience), I gave Nora a certificate that was worthy of framing. In return Nora came to my library to bid me good-by, but totally ignored Hortense. I can see the maiden now, dressed in her very best "afternoon-out" garments, as she stood in the doorway.

"Good-by, Misther Dexter," she said. "Ye hev always threated me loik th' gintleman that ye are. There may be them as says ye hev a hoi 


\section{AND THE WILDERNESS BLOSSOMED}

timper, but as f'r me, I can only say I niver saw it." Hortense always laughs at this and persists in believing that, somehow or other, the remark was not intended to be complimentary.

The plumbing about the house was started by a boat engineer assisted by one of the guides, Deck Huntoon, and later Deck became boss plumber. The adaptability of these men is something wonderful. They seem able to turn their hands to any sort of work with the least possible instruction. The plumbing was well done, and we have never been troubled with leaking pipes. At first four kerosene barrels, connected by short pieces of iron pipe, did duty for a tank, and later, when a professional plumber settled in the village, he built us a cedar tank and lined it with copper; but the barrels did very well for several years, and the water, even at first, had no taint of oil. For several years we used the lake water for all purposes, - and most excellent, pure water it was, - pumping it into the tank with a force pump worked by hand. To save labor, I got a hot-air pump at a cost of two or three hundred dollars, but it was little improvement over hand-power. It pumped little if any faster than the hand pump, and a man still 


\section{IN THE BEGINNING}

had to spend his time watching it while it was working, for if he left it alone it was sure to run too fast or too slow, or do something that it ought not to do. As time passed, I became afraid to use the water of the lake for drinking purposes, the population on the shores having greatly increased. I had bought a farm of three hundred acres on the south shore, and I determined to bring my water from there by gravity. I dug a well on the hillside about I 50 feet above the surface of the lake and proposed to run a pipe from it to the island. All my friends told me it could not be done, except Bridgewater, who said it could be done easily. $\mathrm{He}$ was an engineer with an international reputation, and his opinion comforted me greatly. Unfortunately he failed to tell me how it was to be done so easily, and later when I got well into the job I wished I had thought to ask; but we did it ourselves with no tools at all except a spade, a crowbar, a wrench, an axe, and fifty oil-barrels. The distance across the water was just half a mile, for we had measured it on the ice the winter before we laid the pipe. The bottom was very favorable, with no steep declivities, running down 


\section{AND THE WILDERNESS BLOSSOMED}

from the island shore gradually to a depth of sixty-three feet and then rising a little more abruptly to the main shore. Our pipe was of galvanized iron, $I \frac{1}{4}$ inches in diameter, and came in lengths of about sixteen feet. The ends had to be screwed together, and I felt that this could not be done successfully on a boat constantly kept in motion by the waves, and you never can be sure of calm water on the lake for more than a couple of hours at a time. In the end we put the pipe together in four sections, each about 700 feet long, and these were laid up the hill on the farm shore. They were kept off the ground by poles, pegged down solid, so that they would not move when we started to drag the pipe down the hill. One danger which we did not dare to risk was getting the pipe jammed between rocks on the bottom; and to avoid the possibility of this, we decided to float the pipe over near the surface. We therefore borrowed all the empty oil barrels we could find in the village, carried them to the farm shore, and tying a piece of rope around each, left three or four feet of it hanging. Then we put a plug in the end of the first section of pipe and waited for a calm day. When it came 


\section{IN THE BEGINNING}

we went over in the little steamboat, one man remaining in her with the engineer, to manage the tow line. One man looked after the barrels, another after the pipe, and three men went up the hill to ease the pipe down when we were ready, while I stood on the shore with a megaphone and gave the word of command. The tow line from the boat was fastened to the pipe, an oil barrel tied a little farther up to act as a buoy, and at a word the engine started and the pipe moved easily down the hill. Every few lengths another barrel was fastened to the pipe and the whole moved out into the lake without a hitch. When the end of the first section reached the shore, the boat stopped and the second section was quickly fastened to it with a union joint. Again we started, and the two sections seemed to move as easily as the first alone had done, and so the others followed, and the end of the pipe was safely landed on the island. The floating barrels looked like the corks of a colossal fish-net, quite crooked at first, but a little steady pulling by a couple of stout men soon straightened it out. A few extra lengths were screwed to the island end to allow for the depth of water, and then we cut loose the barrels, one after another, and the pipe 


\section{AND THE WILDERNESS BLOSSOMED}

sank safely to the bottom, having been laid in sixty-three feet of water, half a mile in length, in one hour and twenty-two minutes. In the fall, when we leave the island, the pipe is disconnected at the shore ends and the whole lies safely on the bottom below the possible action of ice or frost. It has worked to perfection for several years past, and water flows freely into our tank, giving us an ample supply at all times.

It was a matter of not a little difficulty to turn some acres of woodland into a lawn. Of course I could have cut down all the trees, and with plough and harrow quickly graded it into proper slopes, but I would willingly do anything rather than lose my trees. They were the beauty of the island, and grass and flowers would be a poor exchange for these monarch Birches, Pines, and Spruces. Growing in the thick woods, covered with moss and ferns, the roots of even the largest trees were close to the surface. Cutting out the underbrush let in the sunlight, which killed the ferns and moss, leaving bare the great roots. So earth had to be mounded over them, and, to avoid tearing the roots, the tilling of the soil had to be done slowly with shovel and pick, instead of rapidly with plough and harrow. But it was 


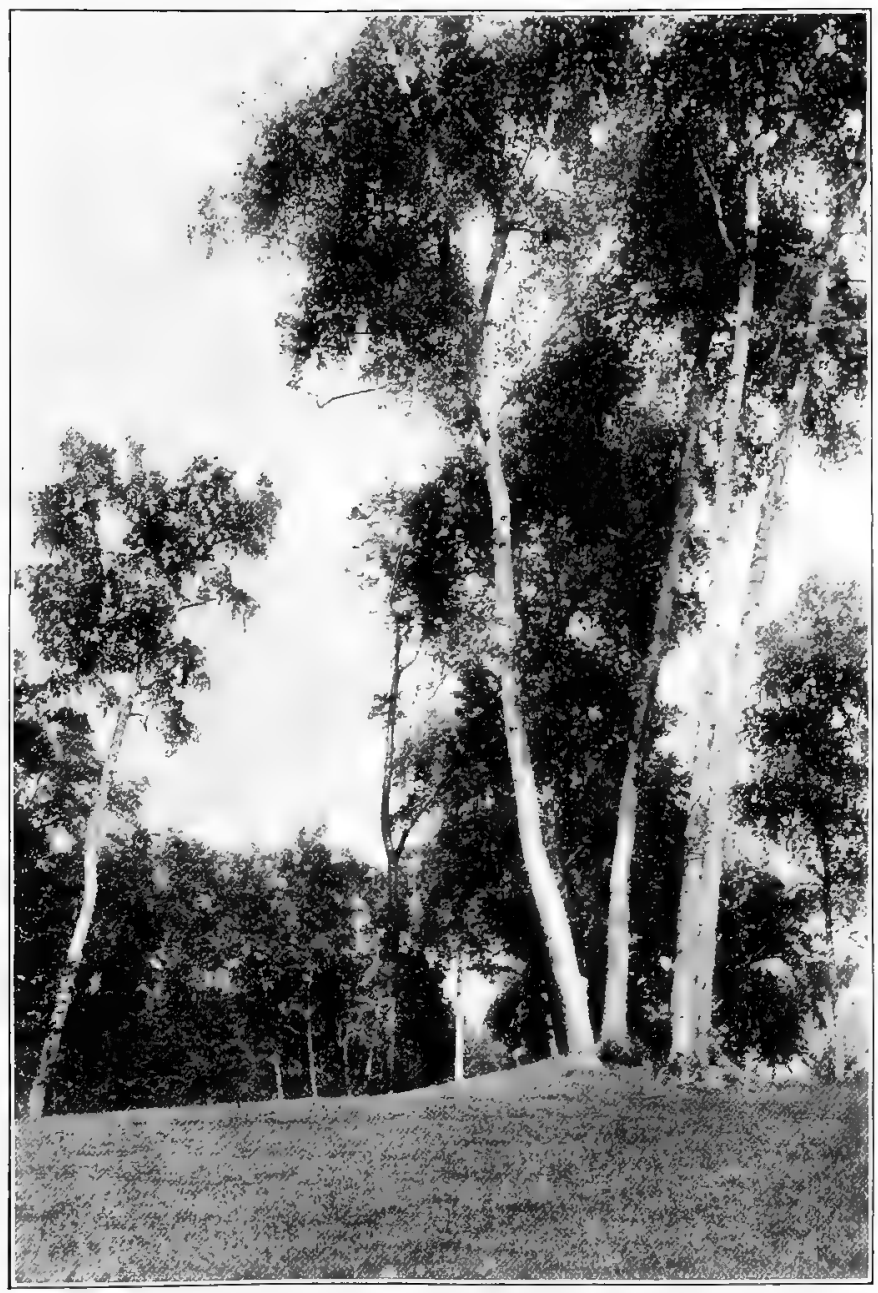

Trees and Lawn 



\section{IN THE BEGINNING}

worth the trouble, time, and expense to save these grand old trees, which bore traces in every limb of their struggle for existence. Twisted, turned, and crooked, it would be impossible for man to rear them thus if he would. Once I saw John Burroughs standing on the hillside gazing with evident delight upon these gnarled old trunks. He mused awhile, and then his face lit up with a smile, and he nodded his good, gray head, and said quietly, "Yes, they're classic! That's it! Classic!"

The first trail from the wharf to the house I spotted on the trees myself, and the men followed with their axes and cleared out the path indicated. Then the stumps were taken out, and plough and harrow levelled off the surface. This was only provisional road-making, of course. We needed earth in every direction to fill hollows, and to cover the roots of trees, and the only place we could get it was from our road-bed. We carted away the good soil and filled the holes we had made with rocks and stones, taken from the spaces we had gone over with pick and shovel, using enough of the underlying gravel to cover these rocks and make a smooth surface for our road. This gravel was what is known as hard pan, - a mixture of 


\section{AND THE WILDERNESS BLOSSOMED}

gravel and clay, which when exposed to the sun became very firm and hard, making with its foundation of stone a most excellent road.

It is said that it takes two hundred years of patient care to produce a perfect lawn, and judging from the slow improvement of my own sod, I am almost inclined to believe it. When you attempt to cultivate a piece of land such as that on the island, you will find that much of what you thought was solid earth is in fact largely composed of scurf, half-decayed wood, old tree-trunks, and the like. As these decay still further, the surface falls off into hollows, and you are tempted to dig up once more the entire plot, but do not do so. You would lose thereby the effect of work already done, and go back to where you were years before. It is much better to cart fresh earth to the spot, and fill in the hollows, sowing grass-seed on the top. A very considerable portion of our lawn is in bad condition owing to the quality of the seed which was sown. At first, being ignorant, I presumed the best seed for the lawn must be the mixed lawn-grass seed of the dealers, which they praised, so highly. When the seed developed into plants, I found to my horror that I had nearly a solid mass of what is 


\section{IN THE BEGINNING}

called Sheep's Fescue. Now, Sheep's Fescue is rather a fine grass which grows in a compact tuft, and in growing, its roots work up high in the centre of this tuft; then, when the lawn-mower passes, it cuts down into the roots in the centre, leaving an ugly, dead, brown spot. It may be that this species of grass is looked upon with approval by sheep, as is suggested by its name, but no animal with a higher degree of intelligence than a sheep would sow such seed on a lawn. Of late years I have bought only pure seed of a single variety, and have found Kentucky Bluegrass the best. Red-top is also good and perfectly hardy. With either I mix Alsike Clover, which has a beautiful effect on the lawn, and gives a noticeable fragrance to the summer's breeze.

When we came to clear out the underbrush on the island, we found innumerable small trees everywhere. I insisted that the man with the axe should leave one of these young trees standing within at least every ten feet, picking out the best for saving, and in case of doubt, to leave two untouched until I decided their fate myself. Of course, none of the large Birches were to be cut at all. Our principal shade-tree, either 


\section{AND THE WILDERNESS BLOSSOMED}

among the old or young groups, was the Birch, of which we had two species, the Paper, or Canoe Birch, and the Yellow, or Silver Birch. The well-known Rock, or Sugar Maple, is common in this region. A few Elms are also to be found; but as we had none on the island, I transplanted a dozen young trees some years ago, and all lived and are thriving. One of the most beautiful of our smaller trees is the Mountain Ash, which grows freely in this part of Maine. In the forest it grows tall, and is apt to be somewhat ungainly, but given plenty of space it develops symmetrically and is a most charming feature on the lawn, with its clusters of white blossoms in the spring, and its brilliant bunches of red berries in the fall. A year of profuse bearing is sure to be followed by a season of scarcity; and when the crop of berries has been remarkably generous, we will often have two successive years with scarcely any fruit. The White Pine once covered Maine with dense forests, while now there are but few left in the State. We have, however, about six large trees on the island, and numerous small ones are scattered about in the woods and on the lawn. The Spruce still is present in the forests in consider- 


\section{IN THE BEGINNING}

able numbers, but the trunks are rapidly being converted into wood pulp. For structural purposes in building, the Spruce has taken the place of the Pine. This tree when small, if given plenty of room, looks well on the lawn, but is not equal to the Balsam Fir in my opinion. The inner branches of the Fir die off as the tree grows old, and unless these are carefully pruned away, the tree soon assumes a ragged appearance. It is found everywhere in this part of Maine, and its tender sprouts are eagerly gathered by summer visitors to make into pillows, which preserve their delightful fragrance for years. The best time to gather the balsam tips for this purpose is in June or early in July, when the young sprigs have just started out from the ends of the branches. They are tender and soft then, and, it always seemed to me, of more delicate fragrance than if gathered later. The trunk of the Fir is of little value for timber, as the heart is apt to decay before reaching a very large size. An important tree here is the White Cedar, which grows everywhere in moist grounds. It is attractive on the lawn if planted out when small, and all are familiar with it when used for hedges under the name of Arbor Vitæ. The wood is the most valuable now 


\section{AND THE WILDERNESS BLOSSOMED}

standing in the forests of Maine, being largely used in the building of boats and for shingles. The American Larch, Tamarack, or Hackmatack, grows in moist lands in this region, and its timber is valuable; the curved trunks from the swamps making excellent knees for large boats. The young tree is handsome, and will grow well even in comparatively dry situations. I have tried a number of other shade-trees, reputed to be hardy, but without much success. A row of Weeping Willows planted at the shore of the lake lived for two or three years, and grew rapidly, and then an especially severe winter killed them all.

All these trees may be successfully transplanted, with proper care. The first necessity is to save as many of the roots as possible; and in this you will find your native hard to manage, for if you leave him to his own devices he will simply thrust a bar under the young tree, and wrench it loose, getting only such roots as may happen to come with the trunk. Maples taken up in this rough way often live, but it will take several years for them to recover after such a rude mauling and show signs of growth. First of all, then, take your tree up carefully, and get with it every pos- 


\section{IN THE BEGINNING}

sible root. Before re-planting, trim back the young branches freely, remembering that a branch should be cut back for every broken root. In setting the tree out, let the hole dug for it be of ample size, so that the roots may be spread out to their full extent. See to this carefully, and don't permit the roots to be doubled back in a bunch. Make the earth snug and firm about the roots, and then if you will keep the soil well moistened for a few days, you will find that your tree will take kindly to its new home. It will be necessary to exercise greater care than ordinary in getting all the roots of Pines, Firs, or Spruces, if you would not lose a large portion of your trees. All these trees may be transplanted in the fall ; but the spring is the proper time, just as the buds begin to swell. With ordinary care I find I lose scarcely any trees transplanted in May, while, of those moved in September, fully one half died, not getting well rooted before the advent of cold weather. 


\section{CHAPTER II}

\section{MEN OF MAINE}

"Wbat a piece of work is man!"

DHE late James G. Blaine once asserted that the purest bred of Anglo-Saxons on earth to-day was to be found in northern Maine. This was scarcely an exaggeration, for Maine was peopled by the Puritans from Massachusetts Bay, and since then the migration of different races from Europe has swept by in a stream, flowing ever westward, and no Celt, Latin, or Teuton has ever apparently penetrated these wilds with the exception of now and then a French-Canadian from over the northern border, or a Blue-Nose from the eastward; and to-day the blue-eyed, light-haired type of man predominates, - the original Simon-pure Yankee, child of the Pilgrim. A chapter of the Colonial Dames, if it were established here, would be forced to take to its bosom every adult female in Insley, if the tracing of one's descent from those who founded 


\section{MEN OF MAINE}

a nation was the real qualification for membership. Many a silk-gowned matron of our cities would give much if she could claim a genealogy showing such a host of colonial celebrities as can that good woman of Insley who gains an honest livelihood at the wash-tub, or by repairing a watch or. a clock at odd moments. Of course I know she is not eligible as a Dame; the washtub may be at the other end of the line, but not this. "Kind o' curious, ain't it?"

Both the men and women of Insley show an odd combination of thrift and shiftlessness. One guide, when out of employment, simply sits down in a corner and smokes, while his neighbor chops wood and works in his garden from dawn until dark, and then, lighting a lantern, picks up worms for bait until bedtime. Passing through the village almost any day in summer, and at almost any hour, you will see a quartet of able-bodied men busily playing croquet, though there may be wood to chop or grass to cut. Like all Yankees, they are keen on a "trade," and never willingly let a dollar pass by without getting a percentage out of it; yet on one occasion a steamboat-captain, having brought a party to the village from a hotel at the foot of the lake, absolutely refused to take 


\section{AND THE WILDERNESS BLOSSOMED}

them back until he had finished a series of games of croquet, and he paid no attention to them, as he saw them prepare to drive back by the road, though this meant a loss of several dollars to his boat. The reverse of this picture is that of a good old farmer who on his death-bed sent for his sons to come that he might bid them goodby, and, after having pressed the hand of each, he sank back wearily on his pillow, murmuring feebly, "Boys, when I 'm gone, you'd better get in that hay ; I reckon it 's goin' to rain."

Some of the women are tremendous workers and need restraint rather than urging, while others, unless you tell them of each particular thing you wish done, will sit for hours in a rocking-chair. If they would read or write or go to bed, I would not mind it, but this everlasting rocking drives me wild.

I know of a storekeeper in northern New York who, when asked for " turkey-red," replied, "I did keep it, but every one got askin' for it, and I was always a-gittin' up to take it down off'n the shelves, so I quit keeping it." Not so in Insley. Go to the general store and ask for a brass bedstead, a steam whistle, a side-saddle, and half a dozen lobsters, and the telephone, telegraph, 


\section{MEN OF MAINE}

and express company will be pressed into service at once, and you may expect to receive any or all of these articles by the next day at the furthest. It has been a common saying amongst us, that if Harry Furbish could not get what you wanted, Charlie Barrett could make it. It is true, too,absolutely so. I have had the shattered cast-iron legs of a sewing-machine repaired by these people so that the places of fracture could not be seen, a main spring supplied to a watch, and a new canvas cover, bound with leather, made for a trunk.

That these people are "cute" and "cunnin" " in a "trade" goes without saying, being Yankees. To them business is a game to be played for all there is in it, and they strive to win as much for the real pleasure of winning as from any motive of gain. Sentiment has no standing at all here in business, and a man will sell his home or his occupation without hesitation, if he thinks he can make a good trade, or with equal readiness will buy out a business of which he at the time knows nothing. Offer the blacksmith " a right smart chance" at a watch, clock, and jewelry establishment, and he will take it in a jiffy, and undoubtedly make a success of it. Deck Huntoon had a fine horse on the island one summer which he 


\section{AND THE WILDERNESS BLOSSOMED}

called "General." Fasten the General to a stump or a rock and yell "Hike there!" and the obstruction had to come if the harness held. The following year I found a sorry-looking beast on the island in the General's place.

"Why!" I exclaimed, " that's not the General!"”

"No," said Deck, " I sold the General."

"Sold the General!" I said with surprise. "Why in the world did you do that?"

"Well," drawled Deck, "I calculate that if any man wants anythin' I 've got more 'n I want it, he's goin' to git it."

Notwithstanding an obvious ease of conscience when it comes to a trade, the Maine man is conspicuously honest. I have known an angler to leave a case of expensive rods on the public wharf for several days, and they were there when he returned, just as he left them, only some one had stood the case under shelter so that it might not be damaged by rain. When our house was being built, I lived in a log cabin alone on the island, and, unprotected by lock or key, kept by me several hundred dollars in small bills and silver, for convenience in paying off the men. I left my camp tenantless for hours in the daytime, 


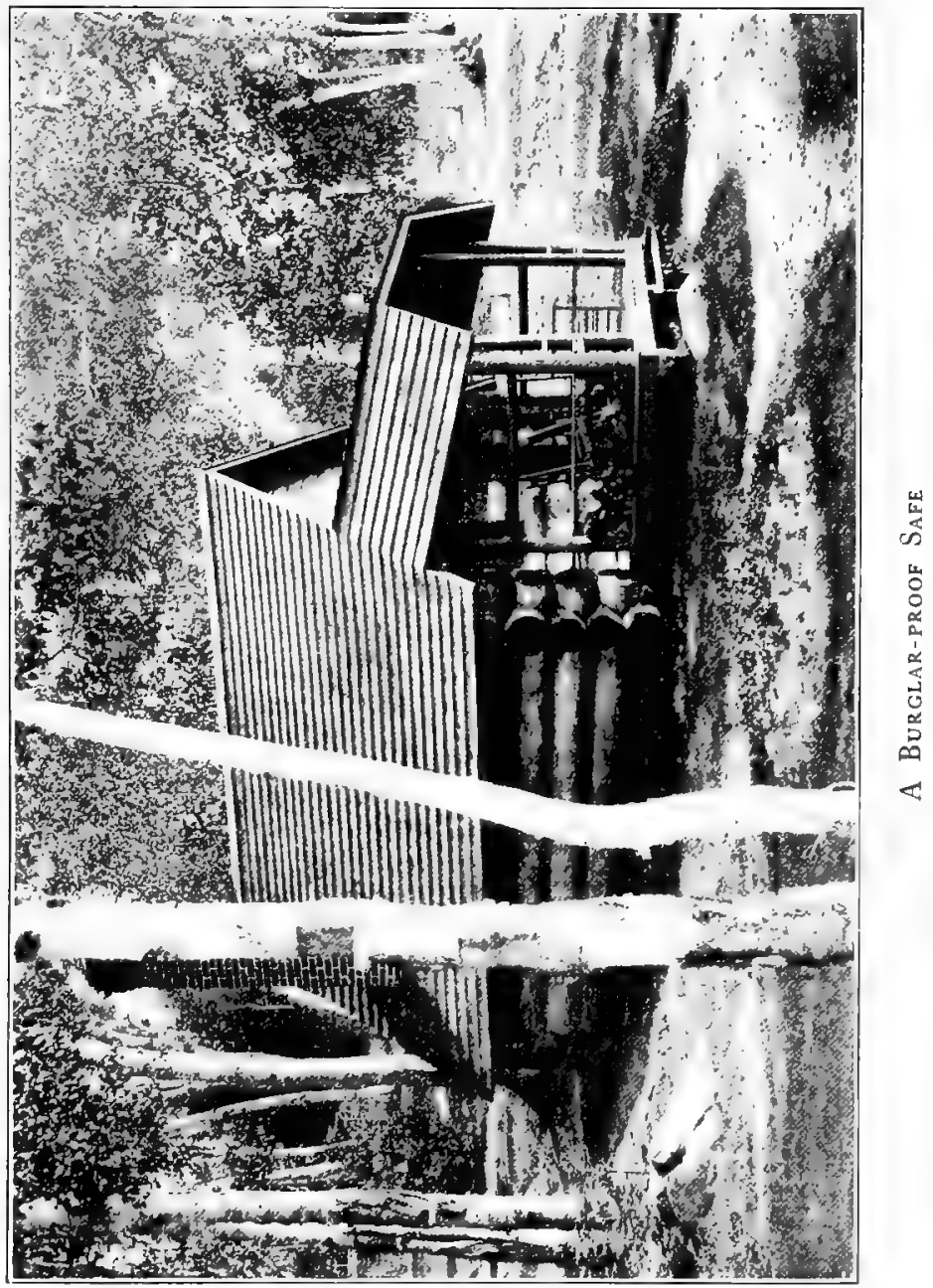





\section{MEN OF MAINE}

and slept there soundly at night, without suffering the loss of a penny or ever having a feeling of uneasiness. Speaking of this to Deck once as something remarkable, his big blue eyes opened wide in astonishment as he asked, "Why, how is it down your way?"

"In the city," I responded, "I dare not go out of my door without seeing that it is locked behind me, for fear some one may slip in and carry off all he can lay hands on."

" My!" said Deck, shaking his head, "I 'd hate to live in a town like that."

A business man may "fail up," and compound with his creditors for so much on the dollar, in the regular course of trade, without losing caste among his fellows; nevertheless, by far the greater number of people are frugal and economical, never spend what they have n't got, pay their debts in full, and therefore don't "fail up." Talking with Aaron Soule once on the expense of living, he remarked, "I tell you, you can't live and bring up a family on less'n about two hundred and forty dollars a year;" adding hastily, "No, not in right good shape."

A thrifty lass is Mary McManus, who makes 


\section{AND THE WILDERNESS BLOSSOMED}

a comfortable living caring for the finger-nails of many a fair woman. Calling one day on a client whose father had lately died, she heard a member of the family ask, "What shall we do with this piece of bombazine?" it having done its solemn duty, hanging by the front door.

"Oh, do give it to me!" said Mary.

"Mercy, child, what would you do with it?"

"Oh, I'll find some use for it," answered Mary, evasively.

She got it, and taking advantage of a similar opportunity later, from the two she made a most attractive black petticoat, and now goes about her work serenely with those mourning emblems draped about her slim figure. Mary is not a Maine woman, but she could give a Yankee girl points on economy.

Maine for half a century past has had a series of laws, of constantly increasing severity, prohibiting the sale of intoxicating liquors within her borders. Yet I have travelled from New Orleans to northern Maine within the space of a few weeks and never saw an intoxicated man until I got north of Portland. I do not know that I ever passed north of Portland without seeing at least one passenger much the worse for 


\section{MEN OF MAINE}

liquor. Once at Lewiston, when the State fair was in session, the car filled up with men going home from the fair, of whom quite one half had evidently been drinking too much. A chatty old man of the party who took a seat beside me told me that on the fair grounds there were not less than twenty booths in which liquor was openly sold. "That's our Depity Sheriff," he said, with a smile, pointing to a big fellow with flushed face and bloodshot eyes, who seemed to be making for the platform. "Sit down, Jim," he yelled. "Do ye want yer neck broke?" As Jim sat down, the old man turned to me confidingly and whispered, "About Monday Jim'll snake in some fellow up our way for sellin' liq'r."

An investigating committee at Lewiston reported that there were not less than fifty places in that city where liquor was being openly sold, and of these fifty the names of not less than thirty-nine of them appeared on the court dockets under indictments in the year 1899 , against whom I 82 complaints had been made, out of which sixty-nine convictions, followed by fines, were had, only one dealer having been sent to prison. The fines averaged $\$ 324$, and the committee 


\section{AND THE WILDERNESS BLOSSOMED}

declared that none of these men stopped business for a day, the bar-tenders continuing to serve liquor while their employers were receiving the sentence of the court.

No man need go thirsty in Maine, even though he never touches a drop of water. Order what you will at almost any hotel or restaurant, and the chances are that you will get it, though your champagne may be served in a teapot and your Bass's ale in a coffee-cup. Tell the first man you meet that you want a drink, and it is quite possible that he will lead you into a sidestreet, and there extract a whiskey bottle from his capacious pockets. In our forest town there are not less than four men who have taken out United States licenses to sell liquor. This does not give them the right to sell in a State where selling is prohibited, but without such a license the seller has the Federal as well as the State authorities to contend with.

Under the law a Deputy Sheriff has the right to visit the office of an express company, and if he simply suspects that a package contains intoxicating liquor, he has the right to open and examine it. If he finds nothing, he simply closes it up again, while if he finds liquor he takes it 


\section{MEN OF MAINE}

into his possession, and notifies the consignee to appear before a magistrate and prove, if he can, that he proposes to make a proper use of it. The magistrate may then, in his discretion, return it, or destroy it, or hold it under advisement in his own cellar.

The Maine man will not willingly interfere with the traffic if such interference means a loss to general trade. The large hotels in the cities keep open bar, and the place is raided only often enough to make the fines count as a fair license fee. As a stranger I stood by the clerk's desk of a city hotel and heard a gentleman complain loudly of the quality of the gin cock-tail served at the hotel bar. "Front" was summoned and quickly brought the white-aproned bar-tender to the desk, where complaint and answer were volubly gone over in my presence, the bartender contending that the true source of complaint was that the gentleman only desired a larger measure of gin. "He wants his cocktails mixed in a beer-mug," the artist declared. There was not the slightest attempt at concealment of the traffic. The large summer hotels supply liquors of all kinds to their guests, and wine is served at meals in public. To stop this 


\section{AND THE WILDERNESS BLOSSOMED}

would drive visitors elsewhere, and this Maine will not do. Such hotels are not raided as long as the proprietors confine their ministrations to the guests of the hotel and do not sell liquor to the natives.

Packages may come, by freight or express, to summer visitors, and though billed as wine or liquor, with even the name of the beverage stamped in bold letters on the box or barrel, the sheriff never sees them. The native has to be more careful, and either has his box consigned to a stranger, or he has an innocent barrel of flour sent to him with a demijohn concealed in the centre. Once this liquor is in the hands of the owner it is promptly consumed, even though the effort reduces him to a state of stupefaction. Beer and other light drinks take up too much room, so that those who crave stimulants of any kind are forced to obtain them in a highly concentrated form, and whiskey and rum, of a poor quality, are the ordinary beverages. The difficulty and delay in getting the liquor, and the danger in keeping it, are such that once in hand it is promptly consumed with the effect of making drunkards of the very men the law was framed to protect. The temptation of the open saloon, 


\section{MEN OF MAINE}

with its bright lights and comfortable surroundings, has never been a factor in Maine life for quite two generations, yet I know of no part of the United States where drunkards are so common, in proportion to population, as in the rural districts of Maine. Looking over a list of divorces granted at a single term of a county court, I found that in four out of seven cases the cause alleged was habitual drunkenness, though all of the parties had been born since Maine had adopted her prohibitory laws.

As far as my observation goes, I am convinced that prohibition in Maine does not prohibit, and though it undoubtedly reduces the number of moderate drinkers, it does not reduce drunkenness, but rather tends to increase it, and I feel quite sure that a wide-spread and persistent violation of any law must have in time a disastrous effect upon the character of the people of the State.

Notwithstanding the evils of intemperance, I am ready to confess to a great fondness, coupled with not a little respect, for "Cal," who for so many years held undisputed claim to the title of "Village Drunkard." My good opinion of $\mathrm{Cal}$ was not gained by reason of his inordinate 


\section{AND THE WILDERNESS BLOSSOMED}

consumption of strong liquor, but in spite of it ; for $\mathrm{Cal}$, to tell the truth, was usually drunk, - not stupidly drunk, but brilliantly so; never fighting drunk, but invariably good-natured. Sober, he was quiet and retiring; half-seas-over, he was genial and sociable; while drunk, he was a genius.

In the latter condition he compiled his weekly half-column of local items for the county paper, and much of it was as amusing as any of the work of newspaper wits with a national reputation. Many years ago $\mathrm{Cal}$ walked unsteadily up the village street, and seating himself upon the steps of the little hotel, gazed about him upon the people waiting for the stage. A quiet lad in an armchair caught his eye, and then, gathering himself together for a moment, he broke out with, "Willie, you're a good-hearted boy, but you can't whistle worth a d-n." Having settled Willie, he turned upon the assembled sportsmen, and after examining them carefully for a moment, remarked philosophically, "Well, after all, folks is very much like other people." Then he discovered me, and said pleasantly, "I believe this is the first time I ever saw Mr. Dexter."

"Is that so, Cal ?" I asked. "It's not the first time I 've seen you." 


\section{MEN OF MAINE}

"Well," said Cal, " did you ever see me drunk before?"

"Yes," I answered, "I think I have, and I 've seen you half drunk, and, unless I am mistaken, I 've seen you sober."

"Well, maybe you have, and maybe you 've got a vivid imagination," was his parting observation.

I recall his announcement for the paper of the arrival of one of the prominent summer visitors on one occasion. It was as follows: "Dr. Bringhurst arrived last Tuesday, accompanied by his little dog, Tippy, who during the past winter has acquired seven new diseases."

Here is another item : -

"About seven acres on the island have been painted red. This includes the roofs of all of Mr. Dexter's buildings."

Once a sportsman asked after his wife, to whom $\mathrm{Cal}$ was invariably kind and devoted; and he replied cheerfully, "Oh, she 's gettin' so shiftless she won't even cut the wood."

He was sitting in the store one night with his head in his hands, apparently oblivious to all about him, when the door opened and a stranger entered. "How are you, Fuller?" said some one. 


\section{AND THE WILDERNESS BLOSSOMED}

At that $\mathrm{Cal}$ raised his head, looked at the stranger inquiringly and asked unsteadily, "Are you Fuller?"

"Yes," said the man.

"Well," said Cal, with a benign smile, " if you 're fuller 'n I am, God help you!"

I think Jim Brown could, and would, drink more strong liquor than any man I ever saw, and, no matter how much he took, it never seemed to affect him in the slightest degree, in looks, in gait, or in speech. I never had Jim for a guide, but there were few in the region with wider knowledge of the habits of fish and game. He studied the wind, the weather, and the season, and the sum of them all sent him to a certain spot at a certain hour, and he always got fish. If you supplied him freely with strong drink, you could get the best there was in him, otherwise not. Once starting for a week's camping trip, the sportsman turned over to Jim a gallon of whiskey, informing him that this was his allowance for the week. Before nightfall Jim had taken every drop of the liquor, and left the empty jug beside the trail. Yet all day Jim kept up steadily with the party, with seventy pounds of luggage on his back. Once when in 


\section{MEN OF MAINE}

camp two sportsmen had a bottle of claret between them, and Jim expected much when his turn at the table came. To his disgust, when his employers had moved to the doorway and Jim was ready to sit down, he found the remaining half bottle had been corked up and put back on the shelf. After taking in the full significance of the situation, Jim turned to his fellow-guide and said, "Billy, do you know, this is the first time in three year I 've sat down to my dinner without my claret."

While the house was being built, we lived for a time at the little hotel in Insley, and one of the interesting characters of the region, Squire Burke, made the hotel his home. He took great interest in our operations on the island, and one evening while sitting with him in the office, he asked me impressively, -

"What, Mr. Dexter, do you propose to do about guests?"

"Do about them? I hardly understand you." "Well," he continued, waving his hand now and then with a peculiar little jerk with which he invariably punctuated his sentences, - " Well, I suppose you will have guests at times." "Yes," I answered, " undoubtedly." 


\section{AND THE WILDERNESS BLOSSOMED}

"Well, I should suppose," said the Squire, "that they would feel more comfortable if they were allowed to bear a part of the expense of keeping up the house."

"I hardly know about that, Squire," I said with a smile. "I've had guests elsewhere, and they never seemed troubled from that cause."

Our first dinner-party was given one day at high noon, to some of our acquaintances at the Insley Lake House, and the Squire was an appreciative guest. As he mounted the steps of the hotel on his return, one of the villagers remarked to the old man : "Rather a windy day for ye to be out, Squire. Ye hain't ketched cold, hev ye ?"

"No," said the Squire, drawing himself up to his full height; "I have been dining, at the Island, and the flushed appearance of my face, comes from the wine, we had at dinner."

That dinner-party was evidently quite an event in the old man's life, and he talked it all over afterwards with one of the ladies who had been present.

"I got that letter, inviting me to the dinner, and at first I thought it was from $M r$. Dexter, but I found out afterwards, it was from Mrs. 


\section{MEN OF MAINE}

Dexter, and a very, remarkable, letter, it was. I will keep that letter; " and the Squire paused and mused awhile. Then he asked, "Did you notice that soup?" Yes, the lady had noticed it. "I have dined, in the past, I presume, at some of the best hotels in all New England, and that was very, remarkable, soup. It was good! Then there was that lettis! I could n't eat it at first, because I only had a fork, so I asked for a knife. Did you hear me ask for a knife? Well, I asked for a knife, and then I got along first-rate. Now lettis, is not a very good tastin' vegetable, natur'ly, but this lettis, had a sauce on it, that was good. Then, did you notice those lit-el cups of coffee, and those lit-el spoons? Well, I asked Mrs. Dexter, and she told me, that those lit-el spoons, were just made, for those lit-el cups."

The old Squire rests in the graveyard by the brook, and his tall form, with that face so like to Emerson's, is seen no more upon the village streets. His graceful courtesy and his kindly greetings are but a memory. Peace to thy ashes, gentle Squire!

Ned Grant was a famous trapper in the region years ago, and his quaint phrases, slowly drawled 


\section{AND THE WILDERNESS BLOSSOMED}

out, were often very amusing. Once going into Winnebago, the road seemed to divide, one trail making off more to the left. We took the righthand trail, and as one of the wheels of the buckboard mounted a rock as big as a tea-table, I asked Ned where the other trail went. "Oh," he said, "that's the old trail. They abandoned it because it was a leetle mite rough."

Passing a clearing in which there was a dilapidated barn and a ruined house, the surrounding land being remarkable solely for the number and size of the rocks on its surface, I asked Ned what had become of the tenant. "Oh, he's retired," answered Ned, "made his fortin' and retired. Ye see that was n't hard for him to do, for his farm was good strong land. It had to be strong, or it could n't 'a' held up so many big rocks."

Once after a successful day, Ned and I had a pint of champagne together, drinking it out of tin cups, - a horrible profanation. Ned smacked his lips over it and remarked critically: "That ain't a bad sort o' drink. I should think that 'ud be first-rate to drink at meals instead o' tea."

Every one who has fished in the Insley region during the past thirty or forty years knows old Richardson. A number of years ago I was down 


\section{MEN OF MAINE}

on the lower lakes with a party, and we stayed at a hotel of which he was then the proprietor. In the evening one of my friends was looking over the register, and the old man was peering over his shoulder. Suddenly his long bony finger was stretched out and rested on a name on the page before him. "What do ye make that out to be ?" he asked.

"That, said my friend, "why, that's very plain. It"s 'W. H. Ramsbottom."

"Well, that's what I thought it were," said the old man, with a relieved expression. "But, do you know, all the time he was here I was afraid to call him it, for fear he'd think I was sassin' him."

Sitting around the camp-fire one night, the conversation turned on odd things to eat, and from the common rat, bird's nests, and the muskrat the extreme appeared to be reached with skunks and snakes as a diet; but one of the guides was ready for a deeper plunge, and asserted in rather a sceptical tone, as if he hardly expected to be believed, that he had heard "that there's places where they eat mushrooms."

There is n't a kinder-hearted fellow in the region than Frank Philbrick, a good guide, and 


\section{AND THE WILDERNESS BLOSSOMED}

always a faithful workman. He was handling a pick one day on the island when a hornet, who seemed much disturbed, came buzzing about, and Frank made two or three vigorous passes at it with his hat. "You be n't afraid of hornets, be you, Frank?" asked Deck Huntoon, who still continued to wield his pick near by.

"All I mind's their sting," said Frank; "I like their looks first-rate."

Driving once through a neighboring village with my friend, the Deputy Sheriff, I asked him what churches they had there. "Two," said the Deputy. "One is the Congregational, and the other a sort of a Union Chap-el."

"And what denominations worship there?"

"The Universalists, the Unitarians, and the Free Will Baptis'."

"That's an interesting combination," I observed. "To which body do you belong?"

"To none of 'em," he answered; "I'm what they call a Christian Baptis'."

"Indeed," I said, "are there many of your faith up here?"

"No," he answered solemnly; "I am the only one."

I have often wondered how my friend the 52 


\section{MEN OF MAINE}

Deputy ever found out that he was a "Christian Baptis'."

Many of the words and phrases in common use are of special interest, and some are easily traced to a local birthplace. For instance, many years ago a French-Canadian by the name of Boubier settled in an adjoining township, and the scattered houses thereabout became known as Boubier Town, to be finally corrupted into Boobytown, and the inhabitants are now uniformly known as Boobies. A guide in the region claims the name of Ex-a-ve-ra, a puzzle at first, but quickly solved when its owner was asked to spell it. The spelling made it Xavier. The mother had read of the Saint and named her boy after him, she and her friends pronouncing it as they would. The waterways running up into the marshes are uniformly referred to as "logans," while the little insects that live there in summer and greet you so cordially when you intrude upon them are always spoken of as " minges," and the flat, bottom land in the valley is called the "medder ground." Now, this is not at all remarkable. It is their mode of pronunciation and it suits them, and that is the end of it. Boston gives herself full liberty in such matters, 


\section{AND THE WILDERNESS BLOSSOMED}

and pray, why not Insley also? The Hub is distinguished for a wonderfully good grocerystore of which Mr. S. S. Pierce was the founder. Now, all the English-speaking world know perfectly well what the letters P-i-e-r-c-e spell, except Boston, and she serenely declares that these letters spell Purse. That she may be consistent, she also insists that it was Franklin Purse who was fourteenth President of the United States. Doubtless they carry this to the bitter end, and a business man of Boston is pursed with regret if he misses an opportunity to put money in his pierce. But what do Boston people do with their brows and their lips? Purse them or pierce them?

One hard-worked word in Maine is "trade." All sorts of buying, selling, exchanging, or, so far as I can understand, entering into any sort of a contract, is to "make a trade." The Deacons of the Church make a trade with the clergyman for his services, and when I told Al Wilbur that Mrs. Landell's French maid was engaged to be married to one of the guides and that she could not speak a word of English, Al remarked with lively interest, "Well, I don't see how they made the trade then."

When these men go off into the woods, they 


\section{MEN OF MAINE}

carry their luggage in a sack on their backs, and from this they have coined the verb "to sack," meaning "to carry." In its application it is usually confined to comparatively light burdens. Thus I never heard a man say he would sack off a load of rocks, but they do "sack out" the underbrush when they take up an armful. One of these men once said to me, "Did you see that little bird? He pulled the fibres out of that door-mat and sacked off all he could carry." Another Maine man speaking of a stormy night in winter said, "It was awfully doin' outside that night."

I have not dwelt on many expressions peculiar in a large degree to New England as they are familiar to all. Many are not Americanisms, but are survivals of old English expressions, which, disappearing in the old country, have been preserved in the new. An interesting example of this was noted at the time of the death of Ralph Waldo Emerson. A biographer stated that the Emerson family came to America in 1630 from the Parish of Woodhill, in the valley of the great Ouse. This statement, repeated in the London Atbenaum, was challenged by a local historian, who declared that there was no such Parish as Woodhill in the valley. More careful 


\section{AND THE WILDERNESS BLOSSOMED}

research, however, disclosed the fact that in 1630 there was a Parish of Woodhill, in County Bedford, in this valley, but that the name had been gradually contracted until nothing but "Odell" was left of it, the original name surviving in the traditions of the Emerson family.

The Maine man dislikes to receive commands, and is therefore chary about giving them, even when clothed with ample authority, and instead of bidding another to do thus and so, is apt to reduce the command to a question, saying to one, "Ain't it pretty nigh time to feed the horse?" or to another, "How'd it be to try your bar on that far corner?" The Maine man has the American dislike to commands in a superlative degree, and the way they avoid giving direct orders to each other is interesting. There is something in the mountain air, the vastness of the woods, that begets independence and a love of freedom. During the Civil War a couple of stalwart lumbermen came from Potter County, Pennsylvania, to Harrisburg, with the intention of enlisting. Walking out to Camp Curtin, they watched with interest a sergeant drilling a file of troops. As the full import of the scene dawned on their minds, one turned to the other, and said, 


\section{MEN OF MAINE}

"Come on, Jim! I'm goin' home. I 'll billy be $\mathrm{d}-\mathrm{d}$ if I 'll walk in two rows for any man." It did not, however, take this class of men long to learn the necessity of discipline in an army, and once this lesson was learned, they made the best troops in the world, as was seen in the career of the famous Buck-tail regiment of Pennsylvania, and was proved on many a field by the lumbermen of Maine and Wisconsin. It is only fair to add that the most unpleasant experience these men had was when they met face to face the mountaineers of North Carolina.

The Maine man is not only chary of his words, but is cautious in his statements. He rarely asserts a fact positively, but is inclined to guess that it may be so, and prefers, indeed, to put a statement in the form of a question, asking another if he does not think or guess that it may be so. This caution of speech was well illustrated on one occasion when my family were moving off from the Insley Hotel, on their way to the island. After watching us a moment a careful woman from Skowhegan turned to a companion and said pleasantly, "Nice people," and then in a moment, possibly fearing she had been too positive, added quickly, "As far as we can see." 


\section{AND THE WILDERNESS BLOSSOMED}

Down on the "Big Lake" there is a colony of camps presided over by a withered little man by the name of Hewey. One of the Judges of the Supreme Court of Massachusetts came there one season to spend a portion of his vacation, and Hewey showed him to his quarters, a detached log-cabin, which he was to occupy by himself alone. His Honor gazed around doubtfully and seemed somewhat disturbed by his surroundings. "I do not know that I quite like this. It seems very lonely. What would one do, for instance, if one were taken ill at night?"

"Oh, that's all right," replied Hewey, cheerfully. "All you 've got to do is to come to yer door an' yell 'Hewey' like $h-l$. ."

It may as well be confessed that Hortense is not a large woman, and her son, as is natural and proper, takes after her. As for myself, I never was remarkable for the robustness of my figure, so that a large and bulgy wife would have been quite inappropriate for me. We went down through the lakes one summer and stopped to inspect these camps. While chatting pleasantly with Hewey, my son passed, and he asked, "'S that your boy?"

"Yes," I replied. 


\section{MEN OF MAINE}

"Well," said Hewey, sympathetically, " he's awful pore, ain't he?"

I acquiesced with a smile, for the adjective only indicated spareness and absence of flesh.

"When I saw him last summer," continued Hewey, "I thought maybe, he wa'n't well. Thought p'r'aps the region did n't agree with him, but I guess it's nat'ral. Hey? That his mother?" he asked in a whisper, as Hortense passed; and to my affirmative answer he replied with a relieved smile, "Oh, well, then, you could n't expect much out o' such a pore couple."

The following year we were down again with a party, my boy not being of the number. As the boat stopped at these camps, we saw Hewey on the wharf, and he greeted us cordially. "What do you think of my boy this year, Hewey?" I asked.

"Why, I don't see him," said Hewey, peering about.

"Here he is," I said, as I laid my hand on the knee of a young friend of mine who was at that period holding up the dignity of the Yale football team, with six feet three of stature and some 


\section{AND THE WILDERNESS BLOSSOMED}

two hundred odd pounds of bone and muscle, at left guard, - " Here he is."

Hewey gazed at him in astonishment for a moment, and then slapping his leg with delight, remarked, "So ' $t$ is. O Lordy! but ye must 'a' fed him well!" 


\section{CHAPTER III}

THE VESTIBULE

"For books are not absolutely dead tbings."

X $T^{E}$ decided that the most convenient place for us to put our book-shelves was in the vestibule, so there the shelves went. And why should they not? Can there be a more cheerful wall-covering than shelves full of books? This passage-way was seven feet wide, and if we had put an ordinary bookcase on either side, we would have found the space much contracted, for an ordinary bookcase is fifteen inches wide, though an ordinary book rarely exceeds six. Some of my books were large, so I made the lower shelves ten inches deep, and then, about four feet up, dropped back to six inches in depth. The shelves are immovable. How far apart they should be placed depends upon the character of one's library. In our case, I found the following dimensions convenient. On one half, 


\section{AND THE WILDERNESS BLOSSOMED}

beginning at the bottom, the first shelf was 18 inches above the base shelf, and the other spaces were I I , $9 \frac{1}{2}, 8 \frac{3}{4}, 8 \frac{1}{2}, 8$, and $7 \frac{3}{4}$, and in the other half I I, I $1 \frac{1}{2}, 10,9 \frac{1}{2}, 8,8$, and 8 . No shelf should be much longer than three feet between supports, for if it is, the shelf will sag in time. There should be no openings behind supports to hide the books from sight. I put no doors at all on these cases, as we have scarcely any dust on the island, and anyway I would rather bear with the dust than be pestered with the doors.

When we came to select our books, we consulted all those lists of " A Hundred Best Novels in English," and the like, and our first purchases were selected from them. Adding to it in after years, we got much that was worthless, all of it highly commended by the reviewers, or insinuatingly included in our packages by the too obliging bookseller.

In attempting to give a list of books for a summer library I approach the task with becoming modesty and cannot hope to please all tastes. None of us would of course make exactly the same list, but in this task I have been materially aided by the friends who have been with us in past years. They have been urged to note on 


\section{THE VESTIBULE}

the fly leaves their views of the books they read, and thus our lists actually embrace the likings and dislikings of a large number of people, and are not the views of the writer alone, possibly in some cases not his views at all. It seems to me that first of all we should select books that the average girl or boy, woman or man, will read, generally rejecting those books that every one has read, unless we believe them to be worth reading again. On such a basis this would be then our

\section{First Choice of Books for a Summer} LiBRARY

Allen, James Lane. - A Kentucky Cardinal; The Reign of Law.

Balzac, H. DE. - Le Père Goriot; Duchesse de Langeais ; Eugénie Grandet.

BARR, A. E. - The Bow of Orange Ribbon; Jan Vedder's Wife; A Border Shepherdess; Friend Olivia.

BARrie, James. - The Little Minister; Sentimental Tommy; Margaret Ogilvy.

Besant, W., and Rrce, J. - The Chaplain of the Fleet.

Björnson, B. - The Fisher Lassie. Black, Clementina.-The Princess Désirée. Blackmore, R. D. - Lorna Doone. 


\section{AND THE WILDERNESS BLOSSOMED}

Bloundelle-Burton, J. - The Hispaniola Plate;

The Clash of Arms.

Browne, C. F. - The Works of Artemus Ward.

Bullen, F. T. - The Cruise of the Cachalot.

Bulwer-Lytton, Sir E.-My Novel.

Bunner, H. C. - Short Sixes; Love in Old Clothes.

Butler, Sir W. F. - Charles George Gordon;

Sir Charles Napier ("Men of Action" Series).

Cable, G. W. - Old Creole Days; Strong Hearts.

Castre, A. \& E. - The Pride of Jennico.

Chittenden, L. E. - Speeches and Letters of Abraham

Lincoln.

Clemens, S. L. - Recollections of Joan of Arc; Innocents Abroad; Following the Equator.

Clodd, Edward. - The Story of "Primitive Man";

The Story of Creation.

Cotes, E. - The Story of Sonny Sahib.

Collins, Wilkie. - The Woman in White; The

Moonstone.

Cooper, J. F.-The Spy; The Last of the Mohicans; The Pilot.

Corbett, Julian. - Monk ; Sir Francis Drake (" Men of Action" Series).

Crane, Stephen. - The Red Badge of Courage.

CRAWford, F. M. - Saracinesca ; A Cigarette Maker's

Romance.

Crockett, S. R. - The Raiders; The Lilac Sunbonnet; Kit Kennedy.

Curtis, George W. - Prue and I.

Dana, R. H. - Two Years before the Mast.

Deland, Margaret. - Old Chester Tales.

Dickens, Charles. - Pickwick Papers; David Copperfield; A Tale of Two Cities. 


\section{THE VESTIBULE}

Disraeli, B. - Coningsby.

Doyle, A. C. - The Refugees; The White Company; Micah Clarke; Memoirș and Adventures of Sherlock Holmes.

Dumas, A. - The Three Guardsmen; Twenty Years After ; Count of Monte Cristo.

Dunne, F. P. - Mr. Dooley in Peace and War.

Eggleston, George C. - Southern Soldier Stories.

Eliot, George. - Silas Marner; Adam Bede; Middlemarch.

Emerson, R. W. - Essays; Representative Men.

Feuillet, O. - Romance of a Poor Young Man.

Field, Eugene. - Poems of Childhood.

Fielding, Henry. - Tom Jones.

Fowler, ElleN T. - Concerning Isabel Carnaby;

The Farringdons.

Freytag, G. - Debit and Credit.

Gaboriau, E. - File No. II 3 .

Gautier, T. - Captain Fracasse.

Grahame, Kenneth. - The Golden Age.

Grant, Robert. - Reflections of a Married Man;

Opinions of a Philosopher.

Gras, FÉlix. - The Reds of the Midi.

Green, A. K. - The Leavenworth Case.

Hale, E. E. - The Man Without a Country.

HALÉVY, L. - The Abbé Constantine.

HARRIs, J. C. - Uncle Remus.

Hawthorne, N. - The Scarlet Letter.

Hervey, M. H. - Amyas Egerton, Cavalier.

Hewlet, M. - The Forest Lovers.

Hocking, Joseph. - The Birthright.

Hope, Anthony. - The Prisoner of Zenda. 


\section{AND THE WILDERNESS BLOSSOMED}

Holmes, O. W. - Elsie Venner.

HoRnung, E. W.- - Irralie's Bushranger; A Bride from the Bush; The Rogue's March.

Howells, W. D. - Their Wedding Journey. Hugo, Victor. - Les Misérables.

Jackson, H. H. - Ramona; Saxe Holm Stories.

JewetT, S. O. - A Country Doctor; A Native of Winby.

Keightley, S. R. - The Crimson Sign; Heronford. Kingsley, Charles.-Westward Ho!; Hypatia.

Kingsley, Henry. - Geoffrey Hamlyn.

Kipling, R. - The Jungle Books; Soldiers Three;

Plain Tales from the Hills.

LaIng, S. - Modern Science and Modern Thought.

LE SAGE, A. R. - Gil Blas.

Lever, Charles. - Charles O'Malley; Harry

Lorrequer.

LiFE. - (Bound Volumes.)

Lover, S. - Handy Andy.

LyAlL, SIR A. - Warren Hastings (" Men of Action" Series).

McCloud, N. - The Starling.

Marlitt, E. - The Old Mam'selle's Secret.

Marryat, Captain. - Mr. Midshipman Easy;

Peter Simple; Japhet in Search of a Father.

Martin, E. S. - A Little Brother of the Rich ; Wind-

falls of Observation.

Mason, A. E. W. - The Courtship of Morrice Buck-

ler; Lawrence Clavering.

Meinhold, J. W. - The Amber Witch.

Merriman, H. S. - With Edged Tools; The

Sowers. 


\section{THE VESTIBULE}

Mitchell, D. G. - Dream Life; Reveries of a Bachelor.

Mitchell, J. A. - Life's Fairy Tales.

Mitchell, S. Weir. - Hugh Wynne; The Adventures of François.

Mulock, D. M.- John Halifax, Gentleman.

"Noblesse Oblige."

Ollivant, A. - Bob, Son of Battle.

Page, T. N. - In Ole Virginia.

Parker, Gilbert. - The Trail of the Sword; When

Valmond came to Pontiac; The Seats of the

Mighty; The Pomp of the Lavilettes.

PARR, Mrs. - Dorothy Fox.

Pemberton, Max. - The Little Huguenot.

Pyle, Howard. - The Rose of Paradise; Men of Iron.

Quiller-Couch, A. T. - The Splendid Spur; Dead Man's Rock.

Reade, Charles. - Peg Woffington.

RiLey, J. W. - Rhymes of Childhood.

Roche, J. J. - Her Majesty the King.

Russell, W. C. - The Wreck of the Grosvenor.

SAnd, Grorge. - Consuelo.

Saintine, J. X. B. - Picciola.

Samuels, S. - From Forecastle to the Cabin. .

Scott, Sir Walter. - Ivanhoe; The Bride of

Lammermoor; Antiquary; Rob Roy; Waverley;

Quentin Durward; Guy Mannering; Talisman; Kenilworth.

Seawell, M. E. - A Virginia Cavalier; Lady Betty

Stair; The Loves of the Lady Arabella. Shakespeare, W. - Plays. 


\section{AND THE WILDERNESS BLOSSOMED}

Sinnkiewicz, H. - With Fire and Sword; The Deluge; Pan Michael; Quo Vadis.

Spencer, Herbert. - Aphorisms (selected by J. R. Gingell).

Stedman, E. C. - A Victorian Anthology.

Stevenson, R. L. - Treasure Island; Kidnapped;

David Balfour; The Master of Ballantrae; The

Wrong Box; Saint Ives.

Stockton, F. R. - Rudder Grange; The Casting

Away of Mrs. Lecks and Mrs. Aleshine.

Stowe, H. B. - Uncle Tom's Cabin.

SwIFT, J. - Gulliver's Travels.

Tarkington, B. - The Gentleman from Indiana;

Monsieur Beaucaire.

Thackeray, W. M. - Henry Esmond; Vanity Fair;

The Newcomes; Pendennis; Barry Lyndon.

Wallace, Lew. - Ben-Hur.

W arren, Samuel. - Ten Thousand a Year.

Waterloo, S. - The Story of Ab.

Watson, Rev. J. - Beside the Bonnie Brier Bush.

Wescott, E. N. - David Harum.

Weyman, S. J. - A Gentleman of France; The Man in Black.

Williams, J. L. - The Stolen Story. Wilson, Sir C. - Lord Clive ("Men of Action" Series).

Yeats, S. Levett. - The Chevalier d'Auriac.

But the above list of books does not by any means embrace all that we should have. In the country in summer we must have near at hand a few good books on nature, and I have gathered 


\section{THE VESTIBULE}

them together here in separate classes for convenience of reference.

\section{Out of Door Books.}

\section{General.}

Аввот, T. C. C. - A Naturalist's Rambles about Home. Allen, Grant. - Flashlights on Nature; Falling in Love.

Burroughs, John. - Wake-Robin; Winter Sunshine;

Birds and Poets; Locusts and Wild Honey; Pepacton; Fresh Fields; Signs and Seasons; Riverby; Squirrels and other Fur Bearers. ${ }^{1}$

Grbson, W. H. - Highways and Byways.

Thoreau, H. D. - The Maine Woods; Walden.

White, Gilbert. - The Natural History of Selborne.

\section{The Garden.}

Gray, Asa. - School and Field Book of Botany. BAILEY, L. H. - Cyclopædia of American Horticulture.

Robinson, W.--The English Flower Garden. Dana, W. S. - How to Know the Wild Flowers. Thaxter, Celia.-An Island Garden. WARNER, C. D. - My Summer in a Garden.

1 If any one refuses to buy nine volumes of a single author, then let him get "A Year in the Fields," which is a selection from the essays contained in the volumes named above. If, however, one really loves nature, and therefore John Burroughs, he will get the nine volumes, and "A Year in the Fields" also. 


\section{Birds.}

Coues, Elliott. - Key to North American Birds. Chapman, Frank M. - Bird Life; Hand Book of

Birds of Eastern North America.

Blanchan, N. - Bird Neighbors; Birds that Hunt and are Hunted.

WRIGHT, MABEL Osgood. - Birdcraft.

Baskett, J. N. - The Story of the Birds.

All these are desirable. If a choice is to be made, I commend them in the order given above.

$$
\text { 4. Fish. }
$$

GünTher, A. C. L. G. - Introduction to the Study of Fishes.

Jordan and Gilbert. - Synopsis of the Fishes of North America.

Marbury, Mary ORvis. - Favorite Flies.

Norris, Thaddeus. - The American Angler's Book. Van Dyke, Henry. - Little Rivers; Fisherman's Luck.

Walton and Cotton. - The Complete Angler. Wells, H. P. - Fly Rods and Fly Tackle.

Yale et al. - The Out-of-Door Library - Angling.

$$
\text { 5. Shooting. }
$$

CAton, J. D. - The Antelope and Deer of America. Mayer, A. M. (Editor). - Sport with Rod and Gun. Seton-Thompson. - Wild Animals I have Known; Biography of a Grizzly; The Trail of the Sandhill Stag. 


\section{THE VESTIBULE}

Equally indispensable is the children's corner on the shelves. In the lists already given there are many books that will interest young people, and the sooner they are introduced to them the better. I remember when my own boy was passing through the inevitable "Henty" age I handed him the "Hoggarty Diamond." $\mathrm{He}$ read it, and as he handed it back to me, asked reproachfully, "Why did n't you give me that before?" Practically the following list is intended for a childless family, but a family that loves children, and now and then welcomes the little ones to its circle. With these books you will have something to give quite as wholesome as doughnuts and lemonade. The family with children will have to add to this little library books varying in character according to the age of the youngsters, but in any case this list will prove, I hope, useful as a foundation for

\section{The Children's Library.}

Esop's Fables.

Alcott, L. M. - Little Women; Little Men.

Andersen, H. C. - Fairy Tales.

Barnes, James. - For King or Country; Midshipman

Farragut.

Bede, Cuthbert. - Verdant Green. 


\section{AND THE WILDERNESS BLOSSOMED}

Bellew, F. P. W. - Chip's Dogs.

Brooks, E. S. - Chivalric Days.

BurnetT, F. H. - Little Lord Fauntleroy.

Busch, W. - Max and Maurice.

Carroll, Lewis. - Alice's Adventures in Wonderland.

Clemens, S. L. - Tom Sawyer ; Huckleberry Finn.

Coolidge, Susan. - What Katy Did.

Cox, Palmer. - The Brownies: Their Book.

DeFoe, Daniel. - Robinson Crusoe.

Frost, A. B. - The Bull Calf.

Grimm's Household Stories.

Habberton, John. - Helen's Babies.

Hughes, T. - Tom Brown's School Days; Tom

Brown at Oxford.

Kemble, E. W. - The Billy-Goat.

LANG, Andrew. - The Blue, Red, Green, and Yellow

Fairy-Books.

Newell, P. S. - Topsy's and Turvy's.

Pyle, Howard. - The Merry Adventures of Robin

Hood; Otto of the Silverhand.

Raspe, R. E. - Baron Munchausen.

Seawell, M. E. - Little Jarvis.

Slovenly Peter. (No family can be properly brought up without "Slovenly Peter.")

Wysz, Johann David. - The Swiss Family Robinson.

A few good books of reference are necessary, of course, and all of the following will be found useful. If you have the Century Dictionary, you will not need Worcester, and while Allibone 


\section{THE VESTIBULE}

is desirable it is not essential in such a library as this.

\section{Books of Reference.}

Johnson's Encyclopedia.

Century Dictionary.

WORCESTER's Dictionary.

Atlas of the World.

Thomas's Dictionary of Biography.

Wheeler's Familiar Allusions.

Allibone's Dictionary of Authors.

To these four essential lists of books I append the following so-called "classics" which are uniformly commended by almost all lovers of good literature. Select from it what you will, but I would put none of these books in a summer library, because I feel assured from experience that few of them would ever be read. Those that are of real interest have been read already by most, if not all, of your friends, while the others will continue to be left alone, notwithstanding the weight of authority in favor of them.

\section{Classics.}

Andersen, H. C. - The Improvisatore. Auerbach, B. - On the Heights.

Austen, Jane. - Pride and Prejudice; Sense and Sensibility. 


\section{AND THE WILDERNESS BLOSSOMED}

BECKFORD, W. - Vathek.

Brontë, Charlotte. - Jane Eyre.

BRown, C. B. - Arthur Mervin.

Browning, Robert. - Poems.

Bunyan, John. - Pilgrim's Progress.

Burns, Robert. - Poems.

Cervantes, M. - Don Quixote. (To me the saddest book in all literature.)

De Quincey, Thomas. - Confessions of an Opium Eater.

De Stä̈l, Mme. - Corinne.

Fitzgerald, E. - Rubáiyát of Omar Khayyám.

Fougú, La Motte. - Undine.

Gaskell, E. C. - Cranford.

Goethe, J. W. - Wilhelm Meister's Apprenticeship.

Goldsmith, O.-Vicar of Wakefield. (Mr. Clemens heartily commends one ship's library because it did not contain this book.)

Gréville, H. - Dosia; Sonia. Johnson, SAmuel. - Rasselas. Judd, Sylvester. - Margaret.

A Kempis, Thomas. - The Imitation of Christ. KENNEDY, J. P. - Horseshoe Robinson. LAMARTine, A. DE. - Graziella. Lamb, Charles. - Essays of Elia; Tales from Shakespeare.

LongFellow, H. W. - Hyperion.

Manzoni, A. - The Betrothed Lovers.

Melville, H. - Omoo; Typee.

Milton, John. - Paradise Lost.

Poe, E. A. - Poems.

Ruskin, John. - Selections. 


\section{THE VESTIBULE}

Sainte-Pierre, B. De, - Paul and Virginia.

Scott, M. - The Cruise of the Midge; 'Tom Cringle's

Log.

ShePPARd, E. S. - Charles Auchester.

SmolletT, T. G. - Humphrey Clinker.

Souvestre, E. - An Attic Philosopher in Paris.

Tennyson, Alfred. - Poems.

Tolstoy.- Anna Karénina.

Turgenev, I. S. - Smoke.

W ARE, W. - Zenobia.

WERNER, E. - She fell in Love with her Husband.

(Good Luck.)

Winthrop, T. - John Brent.

To the foregoing lists $\mathrm{I}$ add a further selection of books which I would buy having both space and money.

\section{Second Choice of Books.}

Aldrich, T. B. - The Story of a Bad Boy. Bangs, J. K. - The House-Boat on the Styx; Paste Jewels.

Beli, Lillian. - Love Affairs of an Old Maid. Burnett, F. H. - A Fair Barbarian; In Connection with the De Willoughby Claim.

Butler, W. A. - Mrs. Limber's Raffle.

CaIne, Hall. - Capt'n Davy's Honeymoon.

Calverley, C. S. - Verses and Fly Leaves.

Chambers, R. W. - The Red Republic.

Cholmondeley, Mary. - Red Pottage.

Churchill, Winston. - Richard Carvel. 


\section{AND THE WILDERNESS BLOSSOMED}

Corelli, M. - Thelma; Romance of Two Worlds. Davis, Rebecca B. Harding. - Silhouettes of American Life.

Davis, Richard H. - Van Bibber; Gallegher.

Dickson, Harris. - The Black Wolf's Breed.

Demolins, E. - Anglo-Saxon Superiority.

Ewing, J. H. - Jackanapes; A Flat-Iron for a Farthing.

FALCONER. - M'lle Ixe.

FREDeric, H. - The Damnation of Theron Ware.

Glasgow, Ellen. - The Voice of the People.

Grant, Robert. - A Bachelor's Christmas.

Haliburton, T. C. - Sam Slick.

Hamblen, H. E. - On many Seas.

Harte, B. - The Luck of Roaring Camp.

Hornung, E. W. - Young Blood; Dead Men Tell no Tales.

Hyne, C. W. - The Adventures of Captain Kettle. Janvier, T. A. - The Uncle of an Angel.

Keighteey, S. R. - The Cavaliers; The Silver

Cross; The Last Recruit of Clare's.

KIng, Ben. - Verse.

King, Captain Charles. - The Colonel's Daughter. Lyall, E. - Donovan.

MABIE, H. W. - Essays on Books and Culture.

Magruder, Julia. - Princess Sonia.

Major, C. - When Knighthood was in Flower.

Matthews, Brander. - The Royal Marine.

Meredith, OWen. - Lucile.

PAGE, T. N. - Santa Claus's Partner.

Phelps, E. S. - A Singular Life.

Phillpotts, Eden. - Children of the Mist.

Quiller-Couch, A. T. - Adventurers in Criticism. 


\section{THE VESTIBULE}

Reade, Charles. - Love me Little, Love me Long;

Never too Late to Mend.

Ridge, W. P. - A Clever Wife; Secretary to Bayne, M. P.

SAgE, W. - Robert Tournay.

Saintsbury, George. - Corrected Impressions. Schreiner, Olive. - The Story of an African Farm. Slosson, A. T. - Seven Dreamers.

Stephens, R. N. - An Enemy to the King.

Stockton, F. R. - The Lady or the Tiger; The

Christmas Wreck; The Adventures of Captain

Horn; The Girl at Cobhurst.

Stuart, R. McE. - The Golden Wedding; Carlotta's

Intended; Solomon Crow's Christmas Pocket;

Sonny.

TAYLOR, M. I. - On the Red Staircase.

Thanet, Octave. - Stories of a Western Town; A

Missionary Sheriff.

Verne, Jules. - Around the World in Eighty Days;

Twenty Thousand Leagues under the Sea; The

Mysterious Island; Michael Strogoff.

WARD, H. -- History of David Grieve.

Weyman, S. J. - Under the Red Robe; Sophia.

Wharton, Edith. - The Greater Inclination.

Whiteley, I. N. - The Falcon of Langéac.

Whiteing, R. - No. 5, John Street.

Wiggin, K. D. - Timothy's Quest.

Wilkins, M. E.-A Humble Romance.

In reading the frank criticisms of some of our readers, as recorded on the fly leaves, I have been often surprised, and always amused, at the 


\section{AND THE WILDERNESS BLOSSOMED}

way they have frequently disagreed with the verdict of the critics, and are at times also quite at variance with the estimate of the general public, if enormous sales be an indication. Here, then, are a few books upon which some people have positive views, with no advertising space to sell.

Allan, James Lane. - The Choir Invisible. One critic writes briefly, "Very able;" while another says, "I can't agree with you. If this book has one merit, it has escaped my careful search. The scenery is as unreal as that on the stage of a theatre. The people are manikins, who play the fool without reason. The hero is a chump, and the heroine an impossible doll. Amy, the other woman, is coarse, vulgar, and slatternly, and yet the book has been compared to Esmond!"

Baring-Gould. - The Broom Squire. "The events described in this story may be possible in England and amongst English men and women, but would not be possible in America. A most unpleasant story of brutal people."

Bloundelle-Burton. - Across the Salt Seas. "Interesting in the main, but marred by its impossibility. What sane man would dream of going over-land to Flanders, after Vigo, when the 'Salt seas' were open to him ?"

Brady, C. T. - For the Freedom of the Sea. "Readable, but it makes one long to be profane in thinking of the English of 1812."

Castle, E. - Young April. "In the main an in78 


\section{THE VESTIBULE}

teresting story. Here and there it drags a bit and is dull."

Castle, E. - The Light of Scarthey. "An absurd story without one sane character in the book."

Crockett, S. R. - Joan of the Swordhand. "Just a story, and by no means a good one."

The Black Douglas. "Simply horrible! With this book Mr. Crockett and I part company."

Daudet, A.-Fromont, Jr., and Risler, Sr. "Characteristically French. Unpleasant, but readable. Clever, but neither great nor proper."

Ebers, Georg. - Uarda. "Very dull at first, with more of interest in the latter half. A historical romance of the time of Moses, not quite successful either as history or romance."

ForD, P. L. - The Great K. and A. Robbery. "Quite impossible, but fairly entertaining."

- The Honorable Peter Stirling. "Amateurish. The love making between Peter and Leonore is nauseating."

_ Janice Meredith. "An utterly worthless book. A man might resign from the British army and emigrate to distant lands because he did not approve of his mother's conduct, but with plenty of money at his command, he would not sell himself as a slave. Again, George Washington never had on his staff an officer who was fool enough or knave enough to announce in a dark stable, within the enemy's lines, to the daughter of a Tory, that his superior officer was sleeping in an exposed place and might easily be captured. The heroine, Janice, is an insufferable piece of baggage, that every man apparently, for some unknown reason, wants to marry, and she at times is evidently ready to 


\section{AND THE WILDERNESS BLOSSOMED}

marry any or all of them. By the most clumsy and inartistic methods the author carries his heroine across country so as to make her present at nearly every engagement of the Revolutionary War, Bunker Hill being almost the only prominent exception. We are duly grateful to $\mathrm{Mr}$. Ford, however, for not putting Janice in the hold of one or another of the vessels in Paul Jones' famous sea-fight."

Gras, FElix. - The Reds of the Midi. "A firstrate story, well told."

- The Terror. "Interesting, but at times it drags. Would have been improved by the slaughter of little Clairet, early in the story."

The White Terror. "I for one have had enough of these Frenchmen. All fools or knaves by the testimony of their own people; and the book is dull."

Gilbert, W. S. - Songs of a Savoyard, and The Bab Ballads. "Very depressing."

Hope, Anthony. - The King's Mirror. "I did not suppose that Anthony Hope could write a dull book, but he can."

Johnston, Mary. - Prisoners of Hope. "Should have been bound in paper and sold for five cents, for messenger boys to read. Absurd all the way through." - To Have and to Hold. "Another worthless dime novel, sold for a dollar and a half. Appeared as a serial in the 'Atlantic,' and selling by the hundreds of thousands. It's amazing!"

JokAr, M. - A Hungarian Nabob. "Jokai is said to be great, and this the greatest of his novels. If this be so, I have had enough of Jokai."

Keightley, S. R. - The Cavaliers. "A good 80 


\section{THE VESTIBULE}

story, but in the name of peace and quietness, how many bands were there who tried to save Charles I., and in how many different ways was it to be done?"

Margueritte, P. and V.- The Disaster. "Not only dull, but absolutely unreadable. Are all Frenchmen mad? Their writers never seem to tire of trying to prove it."

Mason and Lang. - Parson Kelly. "Mr. Mason did much better work alone."

MoncriefF, F. - The $X$ Jewel. "A most inconsequential attempt at a romance. You finish wondering what in the world the author has been trying to do."

Munro, NeIl. - John Splendid. "A Scotch story with the descriptions as well as the conversations in dialect. Think of it! 'No thruadh!' but fortune was a 'dour jade' when this 'sculduddry tale' was put in my 'silvered loof.' It is 'a long strath' and 'stoury marching,' more than a 'meridian daunder,' through its pages, and oh! but ' it is heartsome,' here at the 'cruisie light' of my 'tack house' ('a trig little edifice, not a bigging, but snugly thacked and windowed,' in a 'pleasance walled by whin'), to feel that I have emptied the author's 'girnel and toomed his last basin.' Let this be a 'prickle at the skin' of those who would follow after; let them know that 'here is drool, and the smell of mort cloth,' 'a smittal plague ;' though I am willing to acknowledge at the same time that ' $I$ never heard that a put on gant was smittal,' for every one knows that if a gant was at all smittal it could not be put on.

"I am neither 'pernicketty" nor 'perjink' about my summer reading, but you may notch it on the 'yett" that though the author be a 'gleg man' and 'have repu- 


\section{AND THE WILDERNESS BLOSSOMED}

tation among the snoods,' yet 'in his eld' he will not only look back upon this story 'pawkily,' but still realize that he has been wandering 'on the wrong airt,' and that 't would have been money in his purse had he ' dighted his blade' and 'swithered for a moment,' with 'dour-set jaw,' and then burned or translated his manuscript. Some day he will sound his own 'coranach' for this book, his tears will fall not in a 'smirr,' but in 'runnels' on his 'sark,' his locks will be 'towsy,' and he 'll have 'the slouch of the grangel,' as he sits in his 'byre' and reflects. There are, to be sure, some charming touches in the story, as where we read of the 'braes and corries in Argyle that whisper silken to the winds with juicy grasses,' 'among the bog-flower and the connoch,' where a 'space-wife' and 'ladies with broidery and camisole and washen faces,' witness the 'tinker's death in the sheuch,' while the 'winds blew snell,' and there was heard 'the snorting low of the stirk.' The beauty of the scene is qualified by the fact that 'only in its season the cannoch tuft, and that itself but sparsely; the sturdy gall itself finds no nourishment here,' which will be a surprise to most of us, as it has hitherto been supposed that 'sturdy gall' found nourishment in all Scotland.

"'This story may be 'snod,' but the 'dule of it' all is that it is 'tapsilteerie' to a degree, and, at the best, has no 'swither' about it. Of course, in 'Lochow of the bosky isles and holy,' where 'a scent of wet birk was in the wind,' and 'the river glucked and chattered and plopped most gaily,' one is not surprised to learn that 'the fluff of the wing was heard' as 'the londubh parted his beak of gold,' the 'howlets mourned ' and the crows called with 'roupy voices.' 


\section{THE VESTIBULE}

"At times our author philosophizes; as witness the following :-

" For ordinary our women keen but when they are up in years and without the flowers of the cheek that the salt tear renders ugly; women who have had good practice with grief, who are so far off from the foreworld of childhood where heaven is about the dubs of the door and they find something of a dismal pleasure in making wails for a penny or two or a cogie of soldier's brose.' It seems to me that 'a cogie of soldier's brose' is enough to make anybody wail.

"But think of this:

" 'To walk by a lake and hear grief's chant upon neighboring isles is the chief of the Hundred Dolours.'

This sentence may be a bit obscure, but then obscurity is the spice of Scotch literature.

"There is some feeding and more of starving in the tale. Once 'the straw was burned to dry the grain, the breeze win'd it, the quern ground it, the fire cooked the bannocks of it,' yet, after all, the hero in winter weather with bare legs and but scanty covering elsewhere, was compelled to eat his 'chack' in default of 'bolls of meal.' On one occasion John Splendid finding a "yeld hind' 'despatched and gralloched it with his sigan bubh in a twinkling,' which is interesting, but not surprising, as even a brachiopod might be expected to yell at least once before being gralloched with a sigan bubh.

"The author tells us also of 'the profound gorges of Stob Dubh belching full to the throat with animus,' which will be news to most of us, for while we know Scotland to be fairly full of animus, we did not dream it 


\section{AND THE WILDERNESS BLOSSOMED}

was as full as that. Yet if the gorges of Stob Dubh are as profound as the author hints, why don't they control their animus instead of belching it?

" This book may or may not be 'umquahile,' but if any one would ' homologate' this estimate of its beauties let him 'belt in his breeks,' 'pull up his hosen,' seat himself in his 'chair-haffit,' and read the book for himself."

Pemberton, Max. - Queen of the Jesters. "An odd book which it is possible to read."

The Phantom Army. "Not much of a story."

Kronstadt. "I think I am about through with Mr. Pemberton's stories."

The Impregnable City. "Utter folly. Not a trace of either wit or wisdom."

Rнозсомy,, O.-For the White Rose of Arno. "Very poor."

Stimson, F. J. S. - King Noonett. "Only a fair sort of story."

Pirate Gold. " Not worth reading."

TAYLOR, M. I. - A Yankee Volunteer. "Rather thin in spots."

Warner, Susan. - The Wide Wide World. "An extraordinary book, based upon an analytical synopsis of lamentations. Miss Warner is evidently impressed with the fact that this 'Wide, Wide World' is 'but a vale of tears.' The heroine, Ellen Montgomery, was but a child; but she shows a precocious genius in giving vent to her woe. Mark the variety of her lachrymations which for convenience of comparison are arranged alphabetically. 


\section{THE VESTIBULE}

“Ellen 'almost shrieked,' ' answered with another gush of tears,' and her 'agitation was excessive.'

"She 'began weeping again,' and 'broke forth in an agony of tears.' She 'burst ' on twelve different occasions, nine times 'into tears,' and once each into 'an agony of tears,' 'another fit of sorrow' and 'uncontrollable weeping.' Once she 'almost burst into tears,' and on another occasion 'a burst of tears relieved her.'

"She 'could not help shedding some tears" and she ' covered her face with her hands and sobbed out.' 'She cried' without qualification, and also 'a great while,' ' as if her very heart would break,' 'as if she had never cried before,' 'bitterly,' ' heartily,' ' heartily again,' ' very heartily,' 'for joy' and 'over her letter.' Also she ' had been crying,' 'had had a good cry,' and 'Pilgrim's Progress made her sometines cry.'

"She 'drew long, sobbing sighs,' and something or other 'drew streams of tears down her cheeks.'

"Her eyes ' filled' (twice), 'filled fast again,' ' filled with tears,' 'shone through tears,' 'watered' (thrice), ' were gathering tears very fast,' ' were glistening,' ' moistening,' ' red,' 'swimming,' and 'watering,' while her ' eyelashes were wet' but twice.

"She "fell upon her knees in a perfect agony of weeping' and ' flung herself on the ground to let sorrow have full sway.'

"She gave way to a 'burst of tears,' "a good bit of crying,' 'an overwhelming burst of sorrow' and 'a violent burst of grief.'

"She "hid her face in the towel to cry instead of 85 


\section{AND THE WILDERNESS BLOSSOMED}

making the ordinary use of it,' and through it all 'joy kept company with bitter weeping.'

"She 'mingled bitter tears with eager prayers,' was ' moved even to tears,' while something or other 'opened the sluices of her eyes.'

"She 'poured forth her whole heart in prayers and tears' and 'quivered from head to foot with convulsive sobs.'

"She 'spent a good part of the afternoon in crying,' 'silence was only broken by her sobs,' and she 'shed bitter tears now and then.' She ' sobbed,' 'sobbed more gently' and 'sobbed aloud and even screamed,' 'her sobs went nigh to choke her,' and 'solitude saw many a tear of hers that week.'

"She "threw herself on the floor in a passion of grief,' while something 'threw her back into fresh fits of tears.'

"Her 'tears almost choked her,' 'began to drop again,' 'brought no relief,' 'came faster than her words,' 'dropped into the water,' ' fell faster,' 'fell from the eyes,' 'fell much too fast for eyes to do their work,' ' flowed,' ' Hlowed faster than ever,' 'followed in a flood,' 'gushed forth,' 'had to be wiped away,' 'kept coming all the time,' 'knew no measure,' 'mingled,' 'poured,' 'ran down her cheeks,' ' ran down her face and frock,' ' ran fast again,' ' ran fast down her face and fell into her lap,' ' rose to her eyes,' ' rushed to her eyes,' ' sprang to her thoughts,' ' started,' ' streamed from her eyes,' and 'used to flow abundantly when they could, unseen.' Besides this, her tears were 'blinding her' (twice), ' choking her,' ' fast coming,' were ' in 


\section{THE VESTIBULE}

her eyes' (twice), 'many a time there,' 'poured out fast,' ' running down her cheeks,' ' wet upon her cheeks,' were 'wrung from her,' and, worst of all, 'would drop down on her Bible.'

" ' Unspeakable tears were shed,' "violent tears burst forth,' and indeed 'it seemed as if she would pour out her very heart in tears.'

"She 'watered the rock with tears,' 'wiped away a few tears,' and also 'glad tears,' 'went to sleep with wet eyelashes,' 'words were spoken with a sob' and 'washed down with bitter tears,' and all this time she 'wondered, waited, and wept.' She wept, 'bitterly,' (twice), 'violently' (twice), 'with all the vehement passion of her childhood,' and finally 'wept herself out.' She 'was weeping,' 'as she answered,' 'as she spoke,' 'afresh,' 'very much,' ' with mixed sorrow and thankful joy.' She wept over a 'letter again and again,' and over another twice a day for six days. Besides this she wept 'on her pillow,' on a rock, on Alice's neck, on her lap, on her frock, on the Bible, and on 'poor pussy,' and converted Van Brunt with one application on the back of his hand. On one occasion she ' yielded helplessly to grief,' and on another ' the tempest of tears seemed to gather force as it flowed.'

"Although "now and then the old fit of weeping would come,' 'many were the bitter tears she had known,' and 'many were the silent tears that rolled down and wet her pillow,' 'while even her thoughts resolved themselves into tears,' still she was insatiable, and 'wished to be where tears could burst and her heart could break unseen.' 


\section{AND THE WILDERNESS BLOSSOMED}

"She was a pale, delicate child, and while 'she would weep till she wept her eyes out,' 'her whole frame quivering with hysterical sobs,' ' her heart flowing away in tears,' 'the pent-up tempest bursting forth with a fury that racked her little frame from head to foot,' we are told that unfortunately 'convulsive weeping only exhausted her.' After all this, it is difficult to see why any one should be 'surprised to see several large drops of tears' on her person.

"It would be unjust to assume that Ellen was always in this maudlin condition; and, in fact, Miss Warner takes special pains to point out more than one occasion when she did not cry, although no obstacle apparently offered. Thus we are told that "she almost burst into tears,' ' was almost crying,' ' was in constant danger of bursting into tears,' and 'was in question whether to give way to tears.' On other occasions there was no room for doubt, for we are told explicitly that 'there were no tears,' ' tears did not come,' ' tears could not come then,' 'she did not shed tears now,' and once 'she was too weak for violent weeping,' so of course it was useless to begin.

"After reading this extraordinary book, one is forced to the conclusion that the author could only have secured so great a variety of expression by first preparing such a list as the above, and then checking off each phrase as used." 


\section{CHAPTER IV}

\section{SOME BIRDS}

" Hast thou named all the birds witbout a gun?"

I

DO not propose to write an essay upon the ornithology of the island, but simply to tell something of the familiar feathered friends who spend the summer with us; and of them all, none is more welcome than the Robin. For the first year or two of our life here we never saw a robin, and with good reason, for there were no grassy lawns, and not a worm to furnish food. I feel quite sure about this, for as we dug the land over, we never saw a trace of one; so finally we sent over to the mainland and got five or six quarts of squirming redmen, which we planted in various places on the island. I confess this was not done with a view to attracting the robin, but solely for the benefit of those "Anglers with the Fly" who were beginning to visit us in ever-increasing numbers. These gentlemen all spend hours arranging and re-arranging 


\section{AND THE WILDERNESS BLOSSOMED}

their fly-books, but sooner or later, before starting to fish, are sure to remark carelessly, " $\mathrm{Oh}$, by the way, Deck may just as well dig us a few worms, don't you know." It is curious, but in this paradise for fly-casting, worms are a regular article of commerce; quotations on the exchange vary with the weather, and range from fifty cents a quart in June to more than a dollar in the dry weather of August and September. It was to supply this demand conveniently, that we planted these worms on the island, but it had the unlooked for result of populating our home with robins. To-day, I believe, we would willingly part with every fish in the lake rather than with our robins. They come in increasing numbers every year, and if a large percentage of them did not fall victims to the gunners in the Southern States, the increase would doubtless be even more rapid. I feel quite sure that the same birds return to us every summer, and that the robin (like so many other birds, and fishes too) wishes to build her nest near the place of her birth. As no birds of any kind are ever shot at on the island, excepting only the birds of prey, like hawks, owls, and king-fishers, these robins become ever more familiar and confiding. It is curious how quickly 


\section{SOME BIRDS}

wild creatures learn that you will not harm them, and how willing they are to be friendly. In the past season one pair built a nest on the porch roof, just under the overhanging eaves of the house, and so close to a window that one could reach out and touch the nest. They take possession of the woodshed even, and more than one nest has been built therein.

One year a pair raised two broods in a nest built on a window-sill, and one could stand inside the room and watch the mother at her work. A few little firs were planted last spring close beside the studio, and though they were scarce two feet in height, a robin built her nest in the branches of one and reared her brood successfully. The robin lays four eggs, but I have never yet seen the mother with more than three young, and two is the usual number, though a single youngster is frequently seen. A pair will rear two broods in the same nest in one season, but I have never known a nest to be occupied a second year. This is not so strange, for the robin naturally wants a clean nest to start with, and evidently prefers to build a new home rather than clean up the old one. Many people manage housekeeping in much the same way. They are always moving 


\section{AND THE WILDERNESS BLOSSOMED}

into newly built houses, and when one gets dirty, instead of cleaning it they move to a new one.

The robin is an enormous feeder, and, it is said, will devour half again as much as his weight in twenty-four hours. What a task the mother has, not only to satisfy her own appetite, but also to fill those hungry little stomachs in the nest! I am glad to say, however, that the father helps in this work, and in wet weather one will cover the little ones, while the other forages for food, and then they will change places. After the young have left the nest, they must still be fed for a time; but I have never seen the male help in this task. The young birds follow the mother about, and are eternally crying for more, more, more. She feeds them generously for a day or two, and then cuts down their rations, trying all the while to teach them to help themselves. She will point out a worm to one, apparently urging him to pick it up, and if he fails to do so in a brief time; the mother pulls it out and eats it herself. The youngster scolds and cries the more, and then sometimes the mother will turn and present to him a bit of stick or straw, which he seizes eagerly, and drops promptly, as the mother flies away, evidently laughing. 


\section{SOME BIRDS}

I delight in watching these birds on the lawn. One will hop or run about for a time, then stop, peer this way and that, and suddenly bracing himself, look intently at a certain spot for a second. Down darts his bill, catching the head of the worm as it protrudes from its burrow, and then comes the tug of war. If he has got hold of a big fellow, his back straightens more and more as he pulls, until suddenly the worm loosens his hold and Master Robin has to recover himself quickly to avoid tumbling over on his back. If the birds are still in the nest, and small, the robin is apt to drop the worm on the hard path near by, and cut it in pieces of what he deems a proper size, before flying away to his nest. The robins start South, I think, almost as soon as they are full grown, and in August we see only the ones who have remained to rear a second brood, while by September these, too, are nearly all gone. Even late in the month, however, one is apt to see a solitary belated one, and now and then flocks of a dozen or more will stop at the island for a day's rest, as they pass from breedinggrounds farther north. You are pretty sure to see them then on the gravelly beach taking a bath, as a refreshment after their flight. They 


\section{AND THE WILDERNESS BLOSSOMED}

do not then apparently scatter over the lawns to feed, but are satisfied with a hasty lunch on the ripe red berries of the mountain ash. A few of these birds spend the winter in the severe climate of northern Maine, seeking shelter in the thickets of fir and spruce. Too much cannot be said of the beauty and variety in the song of the robin during the nesting-season, and it is a constant source of delight to me. Quite the reverse is his sharp, scolding note of alarm. His confidence in you evidently has its limit, and if you approach too near his nest, he kicks up a fuss that will disturb every feathered inhabitant of the island, bringing the timid ones to the verge of nervous prostration. Under such circumstances the robin gets mad all over, taking no pains to conceal his feelings, and, indeed, if he does not actually swear, no bird ever did or could.

The White-throated Sparrow, or Peabody Bird, is not so conspicuous in his ways as is the robin, and unless you look for him, you will rarely see him by accident, though he does not appear to be at all timid. It is his beautiful song, however, that impresses itself upon you, as it rings out on a July day, and be the gossip on the porch ever so interesting, some bird-lover is sure to hold up 
a warning finger, and smilingly ask, "Did you hear that?" "I, I, Peabody, Peabody, Peabody," he is supposed to be saying, or in Maine it is, "All day, Whittling, Whittling, Whittling;" but translate it as you will, it gives one a very great pleasure to hear it.

A friendly little fellow, with his bright orange and black markings, is the Redstart (German, Roth Stert, or Red-Tail, though its tail is not red at all), and from early May till July he is in evidence. He alights on the rough bark of an old birch near the corner of the porch, peers about this way and that, chirps cordially, and then flirts over to the porch rail, hops along it, turns a somersault in the air, and lights upon a near-by bush. He peers under the leaves for insects, and then darts away, only to be back again in a moment. I called Al Wilbur's attention to him one day, as I sat reading on the porch. "Yes," said Al, " those birds were over here on the island when we first came. We found one of 'em dead, an' another was livin', but he was terrible slimsy." Poor little flycatcher, you might well be "slimsy" with ice and snow still covering the waters of the lake, and never an insect ready for business. 


\section{AND THE WILDERNESS BLOSSOMED}

Our big chimney was barely built before the Chimney-Swifts came to occupy it. Although in May and June we have fire almost constantly in the three hearths below, these birds seem to have no trouble in nest-building or rearing their young in the midst of the smoke. We hear the muffled flutter of their wings at night, and the cheerful chirpings as they feed their young by day. Now and then one falls on the hearth, and seems too confused by the novelty of its situation to fly up again, but makes its way into the hall, if the fire screen is far enough out for him to escape. Then it beats its wings against the window-panes until taken in some gentle hand to the free air and sunlight. I remember an enormous colony that used to occupy one chimney at Firmins some years ago. Towards dusk they would begin to gather, not by scores or even hundreds, but literally by thousands, circling around the chimney, till at last, all having apparently joined the flock, the circles grew closer and the mass resolved itself into a gigantic funnel through which the birds were seemingly poured into the chimney top. Of course it was impossible to estimate accurately the number of these birds; but the funnel, when formed, 


\section{SOME BIRDS}

seemed to be fully thirty feet high, and as much in diameter across the top, the birds circling about in a dark, compact mass.

Just as you must have a chimney if you would have the swift, and angle-worms if you want robins, so, too, the flower-garden must come before the Humming Bird will visit you. We had had our flowers for a year or two before I noticed the first humming-bird, and it was for some time a rare event to see them; but the increase of late has been very marked, and last season the terrace was simply alive with these beautiful little fairy-like birds. You could not walk along the head of the upper terrace on a bright day in July or August without seeing a dozen or more of them at a time. In August it was curious to see them perching on the trees on the edge of the terrace, pruning their feathers, and then darting off like a flash of light. Doubtless these were young birds, who had not yet attained their full powers of flight. Some young nephews of mine caught a pair of these birds, and kept them in their rooms for several days, the birds seemingly quite contented with their surroundings, feeding freely out of a vial of sugar and water, 


\section{AND THE WILDERNESS BLOSSOMED}

and perching confidingly on the shoulders of their care-takers.

One of the most entertaining of little birds is the Chickadee. He is so familiar and jolly that you cannot feel offended at him no matter what he does. I had tied a bit of worsted about the stalk of the first sunflower to bloom one year, and on passing the bed I found quite half of the still unripe seed had disappeared. Looking at the blossom in surprise, and scarcely two feet from it, I was startled suddenly by a bird who flew by my shoulder and perched on the top of the flower. He looked at me and I at him. I scolded, and he scolded back, and right before my eyes, within reach of my hand, he plucked out another seed and swallowed it forthwith. "Why, you miserable little —" "Chickadeedee-dee," he said, and finished the sentence for me. It was my introduction to the little fellow, and I could not take offence at his thievery. He may have all the sunflower seeds he wants, and he comes every year to get them.

I was walking around the island one day with John Burroughs, and as the path followed the head of a steep bluff, we were suddenly startled by the sound of a watchman's rattle as a King- 


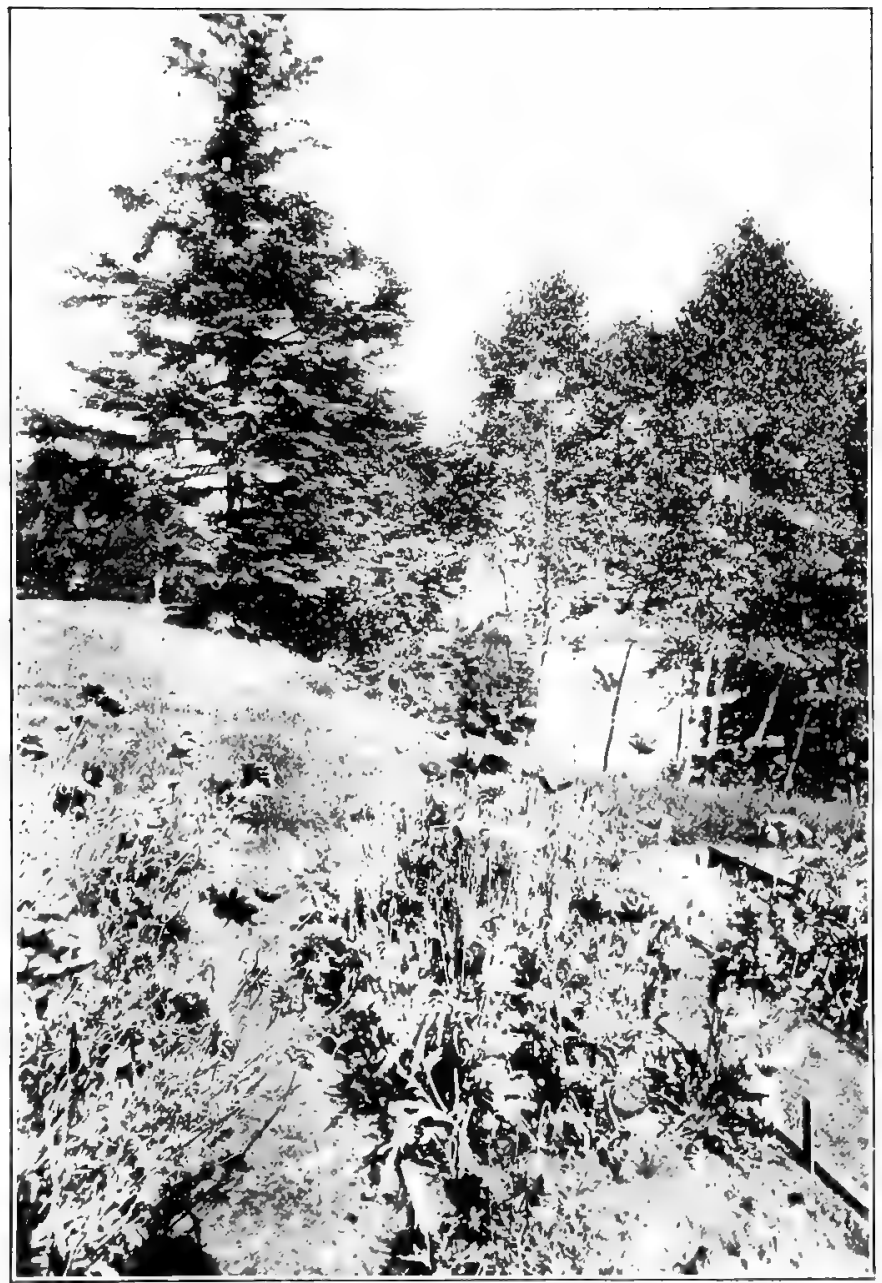

The Garden Beds 



\section{SOME BIRDS}

fisher sailed off over the waters, from apparently beneath our feet. Had I been alone, I would doubtless have passed on with but a casual glance at the disappearing bird, but not so Mr. Burroughs. "There's a kingfisher's nest here," said he, with unerring instinct; and leaning over the bank a moment, exclaimed, "Here it is ; now let's see where it goes."

It was a hole in the bank he had found, and cutting a birch wand and trimming off its leaves, he gave it to one of the lads who were with us, and he probed the opening with the lance. The direction being known, and the distance carefully measured (and it was quite three feet in depth), we marked the probable location of the nest. Pick and shovel were quickly brought, and after digging down in the path about a foot, we unearthed the nest, and one young naturalist's collection was the richer by two highly prized kingfisher's eggs. The boys had permission to practise shooting on the kingfishers for the sake of the young trout and salmon, and the mark is a harder one to hit than any clay pigeon. You think you have him absolutely motionless, as he is poised for a dart at a fish, but invariably the moment you fire he has dropped like a shot on 


\section{AND THE WILDERNESS BLOSSOMED}

the fish below. A number of these birds are shot every year, but they seem to be on the whole quite as plentiful as they were several years ago.

I love to watch the kindly little Chipping Sparrows, and the mother's care of her brood is a lesson for the rest of bird-life, and for human beings also, for that matter. They huddle so closely about the mother, teasing for food so loudly that she always gives it to them, even when they are quite full grown. The English Sparrow, that noisy, quarrelsome fellow, has as yet never landed on the island, and may a kind Providence still continue to keep him away!

Both the Red-headed and the Hairy Woodpecker are residents of the island, the latter being by far the more common of the two. Every year we have at least one noisy nest of Crows, and the Cuckoo is to be seen and heard at times, though not frequently. I saw the Scarlet Tanager but once, while the Red-eyed Vireo, the Red-breasted Nuthatch, the Kingbird, and the Olive-backed Thrush are common, as well as a number of other summer visitors with whom I am not so familiar.

When we began the building of the house, I IOO 


\section{SOME BIRDS}

found the nest of a Black Duck within thirty feet of where the men were at work. It was built at the foot of a large birch-tree, sheltered by brakes and dwarf hemlock. The nest was but a rude affair, but it contained nine eggs. Some of the men tried to capture this wary duck, but she was too quick and cautious for them, and on every occasion she escaped, returning to her nest when she could do so unobserved. She was there for more than a week after we had begun work, and though driven off many times, she managed to hatch her brood successfully. I saw the nest one morning when there were seven newly hatched ducks in it, with two eggs still unbroken, and as I approached all the little ones darted out of the nest and hid themselves beneath the leaves. I found it almost impossible to discover the hiding-place of any of them, yet when I drew away from the nest they one after another returned to it. When I saw it the next day, it was tenantless, the last two eggs having been hatched. This nest was fully three hundred feet from the nearest water, and fifty-five feet above the level of the lake. Since this time I have never seen a black duck on the island, though many nest in this region. 


\section{AND THE WILDERNESS BLOSSOMED}

The Shelldrake is very common, and breeds freely on the lake shores and up the various streams. The Broad-bill and the Blue-winged Teal also breed in our neighborhood, but are by no means so common as the Black Duck or Shelldrake.

To me the Loon is one of the most interesting birds we have about us. The beauty of his plumage and his skill as a swimmer and diver are unrivalled by any other water-bird in the north. $\mathrm{H}$ is cry is like the wail of a lost soul, rising out of the darkness of the night. I have heard his call distinctly for a distance of quite three miles, though the bird itself was not visible without the aid of a glass. These birds are hard to kill on the water, as they dive at the flash of the gun, remain under for a long time, and generally appear again far out of range. It is useless to try to get very near to them; so a rifle must always be used, and I suppose that more than a hundred shots are fired at loons in the State of Maine, for every one that is killed. Three loons having been seen on one occasion, the little launch we were on bore down upon them, and firing began as soon as we were within range. Finally the birds came to the surface within pos- 


\section{SOME BIRDS}

sibly seventy-five yards of the boat. The two younger birds dived promptly, but the mother remained longer on the surface, undoubtedly for the purpose of attracting the shot to herself and away from the young ones, and as a result she was in another moment stretched dead upon the water, a deliberate sacrifice for her young. Although the loon eats many fish in a season, I still do not permit it to be shot at from the island. It is decreasing gradually but certainly in the region, and it will probably not be long before this bird disappears before the advancing ranks of the summer visitor with a gun. The female lays but two eggs, but sometimes raises more than a single brood in a season. The nest is very rude, scarcely more than a hollow in the moss, and is close enough to the water for the bird to slide into it with little effort, for she is but a clumsy and helpless traveller on land. When the young birds are a few days old, the mother pushes them into the water and forces them to swim. They will crawl upon her back, and with them as passengers she will sail out into the lake; then, when she wishes to give them a swimming lesson, she has but to dive, and they are compelled to make their own way on the water. 


\section{AND THE WILDERNESS BLOSSOMED}

My friend the Professor took a lively interest in loons, and refused to be comforted unless he had one of the eggs in just the right state and could examine the embryo. After a protracted search we at last found a nest with two eggs in it, one of which we carried in triumph to the island. Instead of examining the contents that afternoon, the Professor, worn out by his exertions, insisted upon taking a nap, and postponed his work till the following day. At breakfast-time the next morning, I found him on the porch, walking up and down, singing Luther's Hymn in his rich bass voice.

"Good-morning," was my greeting. "How's your loon?"

" Did n't think to look at it," said the Professor, mildly surprised at the question.

"Well, if I were you, I would. Where did you put it?"

"Why, in my trunk, amongst my underwear, so it would n't get cold."

I smiled with all the delight of a boy who hears the first roll of the drum and sees the distant glare of the torches as the procession advances. "You go look at it!" I urged.

My torchlight procession arrived on time, and 


\section{SOME BIRDS}

it was not Luther's Hymn I heard him singing the next moment. The loon had hatched in the cozy underwear, and whatever of the contents of the egg he had not needed, he just left where it was, or trailed it about in his explorations. Some years afterwards the Professor called on me at a Boston hotel, and finding no cards about him, obtained a blank one from the clerk. This was the inscription upon the card :-

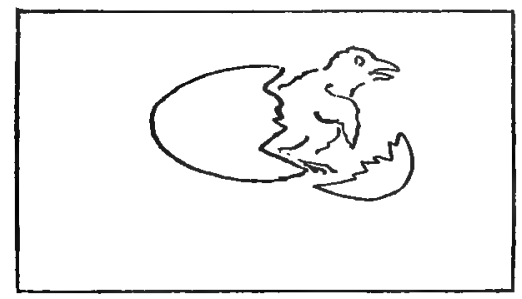

The Ruffed Grouse, called the Partridge (or, to be accurate, Patridge) in Maine, and known as a Pheasant farther south, was a regular resident of the island some years before we owned it; but sportsmen landing there in the fall were able to kill every bird, for they could not fly to the shore, and therefore their extermination was comparatively easy and certain. For some years after our arrival none of these birds visited us; but one spring, on the breaking up of the 105 


\section{AND THE WILDERNESS BLOSSOMED}

ice, three or four of them were fortunately left upon the island. It was lucky for them as well as for us, for they have found at last a restingplace free from their most deadly enemies, man and the fox. I fed these visitors with cracked corn all through the summer, and kept a box filled with food in the wagon-shed during the winter. They raised two broods during the summer, and we had twenty or thirty birds that fall, and though many left in the winter, when the lake was frozen over, we have always ever since had enough left to keep up the supply. Finding that they wished to stay with us, we built them a home of their own, with openings at different heights on the sheltered side of the house, so that they might be at liberty to come in or go out even when the ground was deep in snow. While this house was being built, a cock grouse sat on a log in full view, not more than twenty feet back in the grove, and seemed to be observing the work with interest. There was one bird that became very tame. He would sit at the edge of the woods, and if he saw one of the men going toward the stables, he would gravely follow him, waiting on the outside, and evidently expecting that corn would be tossed to 


\section{SOME BIRDS}

him, as it invariably was. Once he went up a stairway into the second story of the boat-house, and was found in the hall-way above by one of the men, who caught him and carrying him downstairs let him go. When set upon the ground, he did not attempt to fly, nor did he seem in the least alarmed, but shaking out his tumbled feathers, walked quietly off into the bushes. One September a full-grown young bird flew out of the woods, across fifty feet of lawn, rushing blindly against the side of the house, to fall dead on the ground with a broken neck. One day Al Wilbur noticed a mother grouse crossing the lawn with her brood, then almost full grown. The mother, evidently a little disturbed, darted into a near-by thicket, and called to her brood to follow. They all obeyed except one stubborn little chap, who remained behind to attend to some delicacy he had found. The mother clucked her commands again, but still he paid no attention, whereupon she darted out after the disobedient one, and giving him a whack with her wing and an angry peck with her bill, sent him scurrying in short order to the thicket, to which refuge she herself walked back sedately. The grouse is a careful mother, 


\section{AND THE WILDERNESS BLOSSOMED}

and generally rears successfully the greater part of her brood. I have counted twelve young birds in June, and the same flock contained ten healthy full-grown birds in September. Of course there are no foxes on the island, and the only enemies we have to watch for are the owls and the hawks. The latter are not numerous, and the former, from their large size, are sure to be discovered by some one, and promptly shot. We have probably seven species of owls in this region, but as far as my observation goes, only four have visited the island. These are the Great-horned Owl, the American Long-eared Owl, the Short-eared Owl, and the Little SawWhet, or Acadian Owl. Of course it is quite possible that all of these birds may have come to us in search of field mice, to which they were heartily welcome; but as they were all, with the exception of the little Saw-Whet, uniformly suspected of designs on the grouse, they were promptly shot on sight.

Our success with the grouse was so gratifying that we determined to try the Ring-necked, or English, Pheasant. A New Jersey friend was kind enough to present me with some of these birds, and they were taken to the island and I08 


\section{SOME BIRDS}

allowed to rove at will, as free as their companions, the grouse. They made themselves at home at once, nested and brought forth two broods of fully a dozen birds each, the first season. Of these nearly all died in early youth, for the pheasant has a bad reputation as a mother. Possibly this evil repute is gained in confinement, where these birds are very rarely allowed to bring up their own broods, common barnyard hens being substituted. One might expect that in a number of generations the species would, through disuse, easily lose the art of caring for their young; but, be that as it may, it is certainly true that when these birds first came to the island, they did not rear more than ten per cent of the brood, while now, after a lapse of five years, they as certainly rear successfully sixty or seventy per cent. I liberated my birds at first on the lawn, from the box in which they had travelled, and one of them went out of the opening as if shot from a gun. He sailed over the trees and out over the water at a prodigious rate, and we could see him gradually lower, until he fell into the water with a splash, half a mile distant. A boat was quickly sent out, and the bird was picked up more dead 


\section{AND THE WILDERNESS BLOSSOMED}

than alive. The water was very cold, and the poor thing was completely exhausted, being unable to stand when placed on the ground. We carried him up to the house, and turned him over to the tender mercies of Hortense, who took him at once into the laundry and opening his bill gave him a few drops of whiskey diluted with water, and then left him to warm up in his box before the fire. Within an hour he was apparently as well as ever, and the next time he was liberated, he ran off into the woods with the speed of a race-horse, showing no disposition whatever to fly. The following year I got three hens and a cock, and this time I opened the box in the bird-house, and left them there for an hour or so to stretch themselves and regain their equanimity. Then the door was quietly opened, and the birds hopped out, one after another, and looked about. Now the old cock from the year before was one of the biggest birds I ever saw, and in full plumage he seemed to be fully a yard in length, while the new cock was rather less than the average size and weight. These new birds had scarcely gotten out of the house, when the old cock gave his hoarse crow from the edge of the woods near-by, and im- 


\section{SOME BIRDS}

mediately the three hens turned in that direction, the new cock bringing up the rear, apparently in a somewhat doubtful frame of mind. That his suspicions were well founded was quickly proved, for the party had scarcely disappeared into the woods before the little cock came half flying, half running back and making a mighty clatter, with the old cock in full pursuit. Once the old cock saw the intruder driven well away, he returned proudly to the three hens and promptly added them all to his own household. The little fellow wandered about disconsolate and alone for some days, but later I saw that he had enticed one of the hens away from her larger and more brilliant lord and. master, and together they reared their brood. Every fall since then, I have had from twenty to thirty of these birds on the island, but in the spring only four or five are to be found. Some doubtless perish in the cold winter, others fall victims to the wiles of the fox or owl, but some I know wander to the main shore, and take up a home there, they having been seen with their broods at various points about the shores of the lake. The laws of the State protect them at all seasons, and I have no 


\section{AND THE WILDERNESS BLOSSOMED}

doubt that these beautiful birds will gradually increase throughout the region, if they are looked after a little, and protected by the law for a few years.

The past season we had two flocks, each of eight well-grown birds, one of them being as wild and timid as birds can be, while the other wandered at will across the lawns and near the house, feeding like barnyard fowls while the men were at work near by. In both cases the flocks held together, the old cock always in the lead, guiding and guarding the mother and the chicks, who followed obediently in his wake. I know of no more interesting sight than watching these birds and the grouse, as they wander fearlessly over the lawn. To me there is a greater satisfaction in seeing near me a wild bird who shows no fear than $I$ could possibly experience in wringing his neck as I dropped his limp, dead body into a game-bag. Indeed, as the years pass by, I confess to taking less and less delight in murder of any kind.

I was jeered at by all my friends for sending a dozen Quail to the island, and it was freely pointed out that there was not a single " Bob White" in the State, and that as six inches of 


\section{SOME BIRDS}

snow in New Jersey meant certain death to thousands of the species, it was absurd to expect them to survive the deep snows of Maine. As soon as these birds arrived in May, they paired off and we had several coveys of young birds the first year, there being eighty or more of them on the island in September. That winter the snow lay three feet deep on a level, but as the birds always found plenty of food and safe shelter in the bird-house, they survived the storms admirably, and a considerable number of them were still on the island when I arrived there in May. I am quite certain of this, as I not only heard their whistle frequently, but actually saw them. They were there until the first day of June, but after that no trace of them could be discovered. Where they went or why they went, I never knew. They were able to fly from the island to the main shore at will, and had been seen to make the trip frequently from and to a shore over a mile away. While on the island the Bob White made the air resound with his shrill, but to me, delightful whistle. They perched upon the trees and bushes close to the house, and their concert began with sunrise. For some reason or other their call annoyed Hortense excessively, 


\section{AND THE WILDERNESS BLOSSOMED}

and she kept the chore-boy busy all summer driving them away from the neighborhood of the house. She left in the fall vowing vengeance on the race, promising to eat dozens of their relatives during the winter, and declaring that she would never return to the island as long as the Bob White remained. It is a fact beyond dispute that they finally disappeared the very day she returned; but whether it was an accidental coincidence, an answer to prayer, or a pure case of hoodoo, I do not presume to decide.

Having no flower-beds the first year or two on the island, we had chickens in abundance, and they were allowed to roam at will. They chose their nests where they would, and though we had but few eggs, we had no end of broilers in the fall. George Pickens used to catch them, as he wanted them, in a landing-net, but later in the season they got too wild for that, and he appealed for help. The young fellows then used to get target practice shooting them through the head with a twentytwo calibre rifle, which did well at first, but later the chickens moved off out of range the moment a boy appeared with a gun. A larger gun was therefore used; but soon that became of no avail, 


\section{SOME BIRDS}

for at sight of any suspicious person the chickens ran like race-horses, dodging behind every tree. Then the shot gun was turned to, and snap shots had to be taken at the flying fowl while the gunner himself was on a dead run. When we left in the fall we had about forty chickens, wilder than any grouse I ever saw. I suggested to Deck that he might arrange, if possible, with some farmer to board them for the winter "on the halves." When I got back the following spring, I found the island once more well supplied with chickens, and said to Deck, "So you did get the chickens boarded ' on the halves.'"

"No," he replied, "I did n't. I could n't find any one that would board 'em at all. One man said he would n't board 'em 'for the wholes,' so I sold 'em to Jerry Oakes. I got twenty-five cents apiece for 'em and I sold 'em on the foot;" and Deck chuckled quietly to himself. "Jerry an' his boy came over to catch 'em one day, an' they chased 'em all over the island, but they never got a feather. They tried 'em again 'nother day, but had no better luck; so Jerry made a trade with some boys, agreein' to give 'em half of all they could catch. Well, the boys chased 'em all day, and did n't get any; so they 


\section{AND THE WILDERNESS BLOSSOMED}

waited till the chickens went to roost at night, and then they'd steal out under the trees, and catch mebby a couple by the legs. Then they'd have to wait till the chickens got settled again. They was up all night, and as it was powerful cold they nearly froze, but they got the chickens."

"But where did you get these chickens?" I asked.

"Oh, I bought 'em of Jerry Oakes ; paid him twenty-five cents apiece for 'em. Jerry was sellin' out. He 'lowed there wa'n't no money in chickens."

But when the flowers came, the chickens went finally.

We tried ducks too, but the mammoth frogs of the region swallowed the young ones; the old drake murdered a few, the hen got paralyzed from long sitting, and the young ones who survived never got big enough to eat before we left in the fall.

Then four guinea-fowls came, and they were very entertaining for a time. The little spaniel had had much amusement chasing the chickens and levying contributions on their tail-feathers, and he doubtless thought that there ought to be 


\section{SOME BIRDS}

as much fun in the guineas. The first time he tried it, however, instead of running away, the guineas lined up before him like soldiers, and advanced with their saw-sharpening cry on the cocker. He stood his ground for a moment, looking at them in astonishment, and then, before their noisy advance, he turned tail and fled. It was the only time I ever saw this little dog run from anything; but the cheers of the guineas and their martial aspect were too much for him. Then the guineas got to dusting themselves in the flower-beds, and their doom was sealed.

Next came a peacock; who was beautiful to look upon, but he had an objectionable habit or two, in the opinion of some. He would roost on a limb of the highest birch-tree he could find or upon the roof of the house, and through the night he would claw at the shingles in a way that was most alarming and disturbing to the sleepers below. This was not so bad, of course, for I happened to sleep on the first floor; but when this big bird sang, every one within a mile was forced to hear him. Al Wilbur took a special interest in the bird, and the peacock seemed to return his affection, for if he said anything understandable at all, it was clearly, " $\mathrm{O}_{\bullet} ! \mathrm{Al}$ !" 


\section{AND THE WILDERNESS BLOSSOMED}

uttered in a tone of voice as if he were sounding an alarm of fire. The bird seemed so uneasy that we finally decided that he was pining for a mate; so we sent forthwith for a hen, but the result was not encouraging; indeed, it only seemed to double the difficulty. She would perch beside him, and when he yelled, " $\mathrm{Oh}$ ! Al!" she would give a hoarse croak of approval, encouraging him to renewed effort.

The Professor arrived one night, and by sunrise the next morning this pair of big birds were perched upon the porch railing near the naturalist's window, doing their best to give him a lesson in ornithology. The Professor, however, failed to appreciate their efforts, and did his best to dislodge them, but they refused to move, unaffected by either his threats or his blandishments. Then he leaned far out on the window-sill, wild-eyed, his night-dress flapping in the morning wind, and flung the whole contents of his wood-box at these innocent birds. He must have been a bad shot, for he brought down no game, and, his ammunition being exhausted, he was forced to return to his bed groaning in despair. At breakfast-time he told us that he was forced, much to his regret, to return at once to Boston. My 
scientific friend is by no means a skilful liar, and, suspecting him at once, we finally forced from him the whole truth. That night the men, under the Professor's enthusiastic leadership, rounded up the pea-fowl, and driving them into the woodshed, locked them up for the night, when peace settled down upon the island. But the end was near. These big birds must needs also dust themselves, and imagine, if you please, the appearance of the flower-beds after they were through with them. I waited for no formalities; no court-martial was held, but I promptly presented them to Deck, and when he accepted the gift, added, "Then they are yours from this moment; but remember, if I find them on the island to-morrow morning, by the eternal! I 'll eat 'em." 


\section{CHAPTER V}

FLOWER-BEDS

"I know a bank wbereon the wild tbyme blows."

B EFORE attempting to describe our flowers in detail, it will be well to say a word or two on the climate of the island. You must bear in mind that the region in which these flowers are growing is quite far north, and is moreover in a mountainous country, some seventeen hundred feet above the level of the sea. The summers are short, the ice never leaving the lake before the Ist of May, and often covering the water as late as the $22 \mathrm{nd}$, while the remains of snowdrifts are often to be found in June. I have known several inches of snow to fall on the 2oth of May, though it rapidly disappeared. The leaves on the trees begin to glow with their brilliant fall tints as early as the middle of September, and a month later the trees are quite bare. Snow is apt to come early, and when it once begins, the ground generally re- 


\section{FLOWER-BEDS}

mains covered until spring, lying at a depth of from three to six feet on a level. The thermometer sometimes drops as low as $40^{\circ}$ below zero in midwinter, yet notwithstanding this intense cold the ground is never very deeply frozen. Its blanket of snow keeps it warm, and free from frost, and many times I have found the ground ready for cultivation when the remains of a snow-drift still lay but a few feet away. The temperature in summer is never excessive. During the abnormally hot season of 1900, the highest range of the thermometer was $86^{\circ}$ Fah., the maximum record, on the warmest day. Indeed, we rarely have more than a dozen days in a season in which the thermometer rises above $80^{\circ}$. The nights are invariably cool, and one rarely if ever is able to sleep without being covered by a light blanket. Frost is not unknown even in midsummer in this region, though, owing doubtless to the effect of the surrounding water, we never have frost on the island between the Ist of June and the 2oth of September.

In such a region as this none but thoroughly hardy plants can survive. They get the protection of fallen leaves, and the snow which nature provides, but beyond this they receive no cover- 


\section{AND THE WILDERNESS BLOSSOMED}

ing in winter. My object has been to grow only such plants as would stand the cold of our winters without artificial covering, and also such as would produce the greatest amount of bloom with a minimum of labor and care. The shortness of the summers renders it necessary that earlyblooming annuals only be selected, for I have never planted any seeds in the house, nor, indeed, have I cared to grow any varieties which could not be safely sown in the open ground in the latter part of May, and all flowers which would not bloom by the early part of September following were discarded as unsuited to our garden. It must always be remembered that in other localities the results attained would in many cases be quite different, and it is also possible that even with the same sort of climate and soil another might have marked success where I can only register failure.

In giving my lists of flowers I have divided them into two main sections, - first, Perennials and Biennials, and second, Annuals. In both sections I have mentioned the species in the order of their desirability from my point of view. Possibly no other person would arrange these lists in quite the same order, for individual tastes 


\section{FLOWER-BEDS}

not only differ, but a change of locality might render certain plants less desirable, and introduce others which it would be impossible to raise at all in the mountains of Maine. Thus, the farther south we go the less profuse will be the bloom of the Iceland Poppy, until at last we reach a point where it will not live at all in the hot summer. I have purposely avoided reference to the large number of both annual and perennial plants which I have tried to raise, but with little or no success. It is possible that in many cases the seed was defective and would not have germinated under any circumstances, or the manner or time of planting may have been wrong, or again the weather may have been unpropitious, and the seeds rotted in the ground. Every flower, therefore, which I have mentioned I have been able to study for a number of years in the blooming plant itself, and in most instances $I$ have raised the plants from seed, noting the fact specially in describing the species wherever this was not the case.

We have on the island eighty distinct flowerbeds, most of which are simply round beds, seven feet in diameter, though some are long and narrow, while others skirt around the edges of large 


\section{AND THE WILDERNESS BLOSSOMED}

boulders of granite, purposely left on the lawn. Most of these beds are on the southern side of the island, or quite near the height of ground if on the north side. I have had in the past many beds on the northern and western slopes; but as few flowers would do well there, most of them have been abandoned and grassed over. It must be borne in mind also that no portion of this lawn is entirely free from trees, many of them being quite large, some of the birches being nearly three feet in diameter. The location of beds therefore was a matter of some difficulty, as we had not only to avoid the shade of the trees, but the spread of their roots also, which in periods of drought take up every particle of moisture, leaving nothing for either grass or flowering plants within its "sphere of influence."

Once the place for a bed was finally settled, I prepared it for flowers by digging out all the good soil and passing it through a sieve with a mesh of a quarter of an inch. This settled the question of stones in the bed for all time to come. I found the soil a light loam for a depth of a little over a foot, beneath which was gravel. The gravel I removed for a depth of six inches more, and its place was taken by sifted earth and leaf 


\section{FLOWER-BEDS}

mould. This gave me a bed with over eighteen inches of as good soil as any plant could reasonably demand. Every year since, each bed has received a coating of well-rotted manure, about four quarts of bone-dust and the same of woodashes and phosphate, the whole being lightened up with a half-wheelbarrow load of leaf-mould.

On the southern side of the island the land descends rapidly from a height of fifty-five feet to the water. This slope was thickly covered with trees of various kinds, and studded with innumerable bowlders and loose rocks. The trees were cut, the stumps removed, and the tree-tops burned up, over a space one hundred and fifty feet wide at the top and thence down to the water's edge. First of all it was necessary for us to get rid of the rocks, and as it would not do to simply tumble them into the waters of the lake, and to carry them up the hill would have been an expensive undertaking, it was obviously desirable that we should utilize them in some way in the locality where they then were. To begin with, we built a wall along the water's edge to protect the bank, and this somewhat lessened the over-supply of rocks. We next built another wall across the slope, and about one-third of the way up, making the 


\section{AND THE WILDERNESS BLOSSOMED}

wall about five feet high. It was necessary for us to husband the good soil carefully, as we had little opportunity to get extra earth for grading; so, first of all, we dug away all the good soil along the course the wall was to take, and for some six feet back of it, throwing the whole in piles up the hill, and as the wall progressed, rocks were piled in behind it and levelled up to within a foot or so of the top. The soil was then pulled in over these rocks, and that part of our work was done. Of course, an opening, two in fact, had to be made in the wall, and steps built therein of flat rocks. This work cleared out of our way the greater part of the rocks that troubled us, and the balance were used in making still other flights of steps in the eight terraces that were gradually constructed. We took care to save all the good earth in the spaces the steps were to occupy. Some of the gravel, too, beneath it was exchanged for good earth in the paths at the head of each terrace. We were aided much in this work by the fact that at either end of the space occupied by the terraces ledges of slate rock cropped out, from which we were able to split great slabs of stone from four to nine inches thick, to be used for steps. In the 


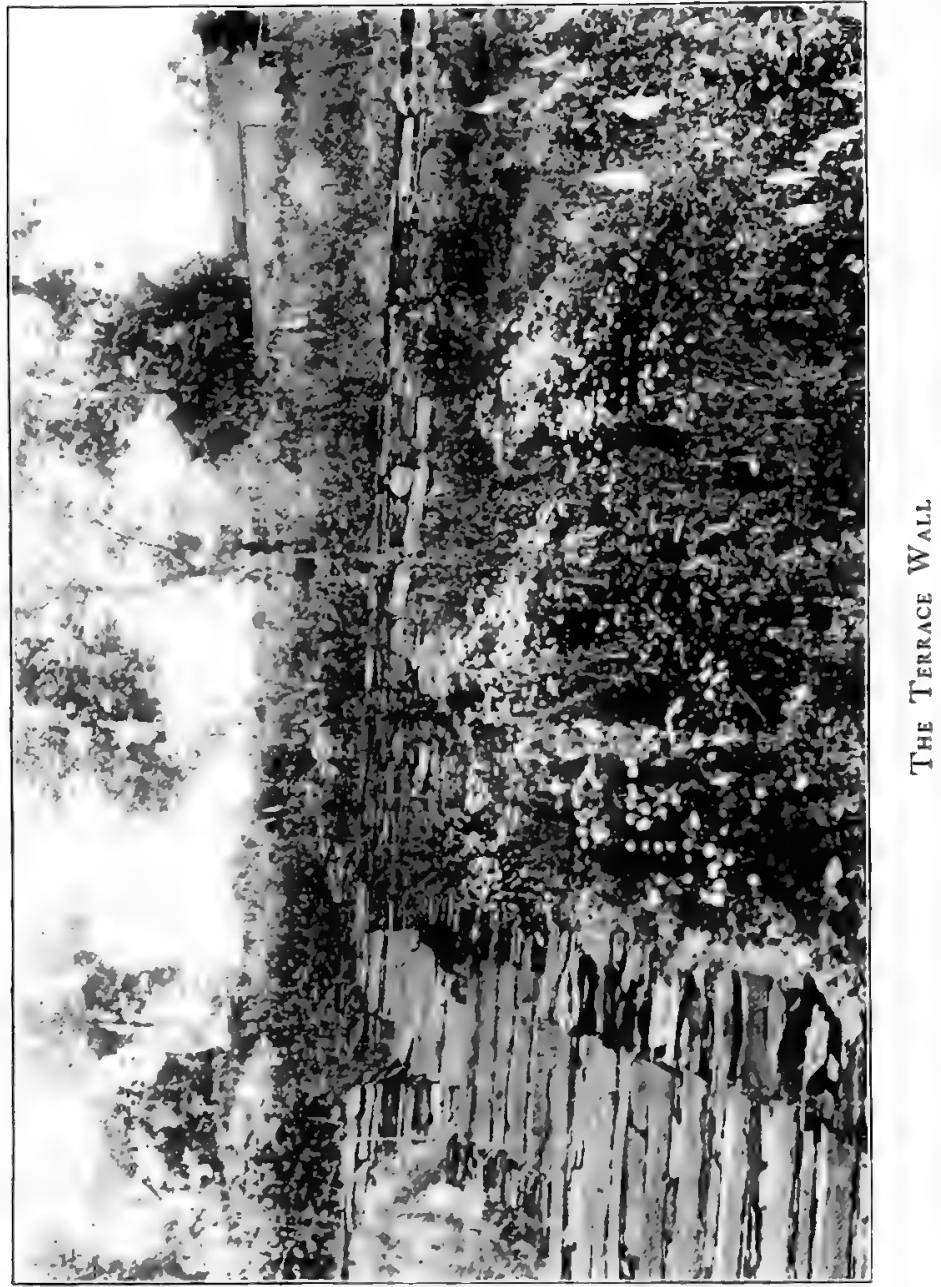





\section{FLOWER-BEDS}

end we had a space of about three quarters of an acre, sloping southward, made into eight terraces, each about six feet in height, the whole being connected with flights of rough stone steps, laid up without mortar; there being sixty-four steps in all from top to bottom. On these terraces, so prepared, we transplanted all our hardy perennial plants. Here they were protected from the cold north and west winds of winter, and the flying snow piled up over the bank, driven by the winds, thus covering the plants with a warm thick blanket of snow. Flowers survived here that had formerly died every winter on the northern or western slopes, and nearly all the species increased both in the size and in the quality of their bloom.

At another point on the southern slope, protected by a thick fringe of woods to the westward, I laid out my garden beds for the rearing of flowering plants and the few vegetables that we cared to cultivate. The space selected measured about forty-three feet east and west, and thirtythree feet north and south, with a slope to the southward. In this space we built fourteen beds, each being fourteen feet long by three feet wide. The beds were enclosed in cedar planks, nine inches deep, supported by stout stakes at each 


\section{AND THE WILDERNESS BLOSSOMED}

corner, and also in the centres of either side, the whole being coated with coal-tar. The paths between the beds were eighteen inches wide, and down through the centre the path was three feet wide, sufficient for a wheelbarrow. The good soil was all passed through the sieve, and the soil from one bed and one path was about sufficient to fill the bed with sifted loam to a depth of eighteen inches. Of course the rocks we found, and the siftings from the soil, together with the gravel taken out beneath the beds themselves, all went to fill in the paths. To compensate for the general slope of the land, each bed was depressed about three inches below its neighbor to the northward, while at the southeastern corner a terrace three or four feet high had to be built up above the natural level of the ground. Each year not a little soil is removed from the beds in transplanting, and the loss is made up generally with sifted leafmould.

I use every season several of the garden beds for testing varieties of annual flowers that are new to me, and such seeds receive the greatest care and attention. We raise here, also, certain small vegetables, gathering all the radishes we require, 


\section{FLOWER-BEDS}

and having also some lettuce, a few onions, and a patch of parsley. Here also I test the possibility of raising certain desirable vegetables in this climate, and if successful, I recount my experience to one of my farmer friends, present him with the necessary seed, and promise to buy his vegetables when ripe. This is quite as satisfactory as raising your own vegetables, and actually much cheaper to you, as you are compelled to raise more than you need in order to supply maximum demands. The farmer of course takes care of himself, and the surplus of his crop may be sold to others. The balance of the space in the garden beds is devoted to the raising of perennial and biennial plants, so that a supply of hardy plants may always be on hand, and each year, also, new species are tested. Considering the large number of plants tested by me in the past, it is remarkable how few I have found worthy of cultivation.

With so large a number of trees on the lawn, we have of course a quantity of leaves to remove every spring. They are carried to a retired corner, and piled up to decay. We have four such piles on hand at all times, the oldest of which is used during the summer on the flower-beds and lawns. 


\section{AND THE WILDERNESS BLOSSOMED}

As we use so much sifted earth and leaf-mould, we always take advantage of a dry period to do our sifting, and quantities of each are stored over winter in barrels, ready for use in the early spring when most needed, and when the wet condition of everything makes sieving almost impossible. 


\section{CHAPTER VI}

\section{PERENNIALS AND BIENNIALS}

"The beaven's breath smells wooingly bere."

\section{I}

SUPPOSE, if I were compelled to choose one flower out of all the perennials and biennials on the island it would end in my selecting the Pansy, Viola tricolor. The pansy is at home in a cool climate. Saved from the withering summer's heat of more southern localities, it is bright and cheerful through July and August. It is true that the flowers are somewhat smaller during the warmer months, yet still there is not so marked a difference after all, and with a little search, in the shadier parts of the bed one may still find a big one on the hottest day of the season.

The books make an enormous business of the raising of pansies, with cold frames, winter covering, and numerous transplantings. I have had the best results with very little trouble. About the first of August I plant my seeds in drills 


\section{AND THE WILDERNESS BLOSSOMED}

in the garden beds, and before frost comes they are sturdy little plants, invariably wintering well without any artificial protection. About the first of June, or even earlier, they are transplanted to the beds, being set about nine inches apart, and almost immediately they begin to blossom, continuing in full bloom until frost. Blooming as they do for so long a period, the seeds ripen gradually, and therefore it is quite a labor to gather them. Moreover, desiring the bloom to continue throughout the season, I encourage picking the blossoms freely, and make no attempt to gather the seed. You can buy the choicest strains from the seedsman, and be reasonably sure that they will germinate. The beds for pansies should be rich, and indeed they can scarcely be made too rich. Well-rotted manure, bone dust, and wood ashes should be dug well into the bed.

Next in order is the Blanket Flower, Gaillardia grandiflora superba, a cultivated variety of G. aristata. Grouped together on one of the terraces, the whole is a mass of brilliant color for several weeks, and at its height one could scarcely thrust a cane through the plants to the ground beneath without touching a blossom. The 


\section{PERENNIALS AND BIENNIALS}

flowers are large, brilliant in color, and last a long time when cut. Its cultivation is of the simplest, and it is readily transplanted in the early spring. As the plants are large and spreading, they should not be set closer together than from fifteen to eighteen inches. On the terrace the plants attain a height of from two and a half to three feet, and the flowers measure from three to five and a half inches in diameter. It is easily reproduced from seed, cuttings, or division of the roots. The seeds are easily gathered, and with little trouble one can obtain all that may be desired. It is better to mark specially large blossoms and save the seed from them alone. The Gaillardia does not seem to require a very rich soil, but I always scatter about the roots in spring a little phosphate, ashes, and bone-dust. It begins to bloom as early as June 2oth, and some blossoms may still be seen until frost, but it is at its best during all of July and August.

The old-fashioned SweET William, Dianthus barbatus, is a prime favorite with me. It is perfectly hardy, and survives the coldest winter if reasonably protected with snow. The colors vary considerably, and are classed generally as dark or light shades, though it would be difficult 


\section{AND THE WILDERNESS BLOSSOMED}

to say to which class some of the heads belong. I plant my seeds in the garden beds in spring, and later in the season, when the plants are well grown, remove them to the beds where they are to remain. The plants may be set out about one foot apart, and I always sow, in the fall, fresh seed in the spaces between the plants. Sweet William is a biennial, blooming the second year, and the plant thereupon dies, after having first cast its own seed. The plants from this self-sown seed will not bloom until the second year, and therefore, if you would have bloom each season, you must sow the seed the same year that you transplant. This will give you a constant succession of blossoms, while otherwise you would find but few blooming plants in alternate years, and indeed you would have none at all but for the belated individuals who had failed to bloom with their brethren. It begins to bloom June 2oth, continuing to the 2oth of August.

Aquilegia, or Columbine, is found throughout the northern parts of Europe, Asia, and America. It is fond of mountain regions, and is remarkable for the brilliancy and variety of the colorings of its numerous species; some of the 


\section{PERENNIALS AND BIENNIALS}

choicest of which are natives of western North America. Among the finest are $A$. carulea, the Rocky Mountain Columbine; $A$. Californica, the California Columbine, and $A$. Canadensis, the Canadian Columbine. Some authorities claim that these species are apt to die after once blooming, but my experience has not confirmed this, and I have plants that have been blooming in the same position for several years past. The common Columbine, $A$. vulgaris, is more brilliant and varied in its coloring than the western American species, which are remarkable rather for the delicacy of their shading. All these species are easily raised from seed, and I have had much more success when sowing the seed in the early spring than at any other time. In my experience the seeds take a long time to germinate, especially the American varieties, which I have known to lie dormant for a full year. The plants are easily transplanted if taken up before beginning to bloom. They like good rich soil, it is said, but they have done well for me in almost any situation, and with scarcely any attention. They bloom from June $5^{\text {th }}$ to July 16 th on the island, though I have had a yellow variety blooming as late as the middle of August. 


\section{AND THE WILDERNESS BLOSSOMED}

Coreopsis lanceolata is one of the most satisfactory of perennials. It is a profuse bloomer, and remains in blossom for quite three months during the summer, beginning the $4^{\text {th }}$ of July and still showing some of its golden coloring at the end of September. It is not perfectly hardy, and it is well to plant a few rows of seeds annually so as to be supplied with fresh plants. The seed is easily gathered, but the blossoms should be marked and only the largest saved for seed. I prefer to sow this seed in the spring rather than in the fall.

A charming companion for the Coreopsis is Scabiosa Caucasica, with its light blue flowers, three inches or more in diameter. Lilac-blue some of the catalogues call it, but that does not quite describe this beautiful shade. It is not so profuse a bloomer as Coreopsis, but it is even more hardy. It is an excellent flower for cutting, and the blossoms last a long time in water. It does not seem to be particular as to its soil, and it does well in bright sunshine or partial shade. It is not very generous in producing its seed, though there is little trouble in collecting and cleaning all that one needs. I prefer to plant this seed also in spring. It blooms from July roth till frost. 


\section{PERENNIALS AND BIENNIALS}

Digitalis purpurea is a noble plant of the easiest cultivation. It is called Foxglove in common parlance, which seems a stupid sort of name, but it is claimed that it was originally known as the Fairies' Glove, or Fairy Folk's Glove, then simply Folk's Glove, and finally Foxglove. This is on a par with the inn kept by the pious Puritan who displayed as a sign, "God encompasseth us," to be changed, as the letters disappeared and tradition only remained, into "Goat and Compasses." Digitalis, according to Gray, is a perennial, but in my experience it is a biennial, and never blooms a second time. It casts its own seed in the most generous manner, and a single stalk may produce fully a hundred thousand seeds. The seeds are very small, but from their enormous number are easy to collect. To the best of my recollection I never bought but a single packet of this seed, getting enough to cover the bottom of a thimble at a cost of ten cents. From this package of seed all of my plants have descended, and with constant improvement in the strain, beginning at a height of three or four feet, they now reach seven or eight feet, and it seems to me that the flowers themselves have increased both in size and in number. This flower is interesting from the 


\section{AND THE WILDERNESS BLOSSOMED}

care it apparently takes to secure cross-fertilization. When the blossom first opens, and the anther is laden with pollen, the style

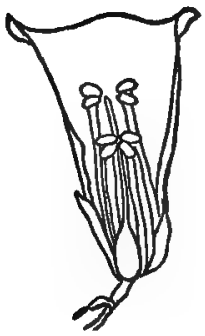
remains tightly closed at the tip, so that none of its own pollen can enter and fertilize the seed. As soon as the pollen is all brushed off, the tip of the stamen opens, funnel like, and the very next bee that comes along is sure to deposit enough pollen from another plant to fertilize the seeds. Watch the bees at work sometime. You will notice that the lower blossoms open first, and they taper in various stages toward the top, where only the green buds appear. Now when the bee comes along, he seeks his nectar first from the well-opened blossoms below, and then works upward. So you see he has deposited his load of pollen on the flower that was ready for it, and as he goes up the stalk he takes on again a fresh load to fertilize the

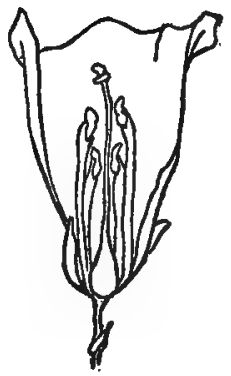
flower on the next plant on which he calls. Take your pen-knife the next time you are in the garden, and slit up the petal of the flower, so you may 


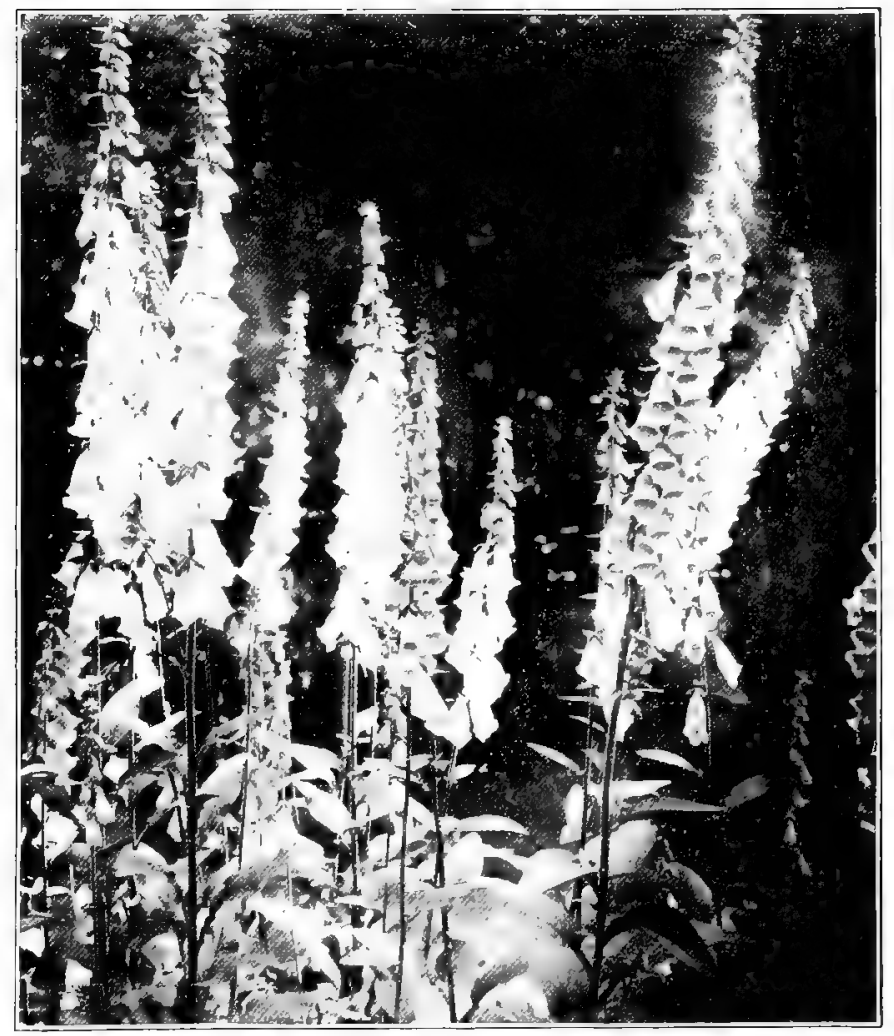

A Clump of Foxgloye 



\section{PERENNIALS AND BIENNIALS}

see all this for yourself. In the mean time these sketches, drawn from nature, will help you to understand it all. I have not planted any of these seeds for some years; the plants themselves do it all. Digitalis does not seem to care what sort of a soil or situation it gets, growing in sunshine or shadow, and has spread even to the neighboring woods. The seeds lodge in the crevices of the rocky steps where no soil at all was intended to be, but there they grow, and thrive, and bloom, even starting up in the gravel walks like very weeds. In color it ranges from pure white to a deep red or purple, with variations of cream and rose, marked with blotches of purple or maroon. The seed may be planted in the spring on the surface, and the earth firmed down about them. They are easily transplanted in the spring and require little if any attention. The great stems of particolored blossoms make handsome decorations for the hall-way. Digitalis is found in different species in northern Africa, southern Europe, western Asia, and one species, at least, in Siberia. It blooms on the island from the Ist of July to the 2oth of August, and is at its best about the last week of July. I have seen, however, a belated individual or two in full bloom the last of September. 


\section{AND THE WILDERNESS BLOSSOMED}

Of all the species of Campanula, unquestionably the most attractive for garden cultivation are the Medium varieties, the well-known Canterbury Bells. They come single, double, and in the "cup and saucer" shape, and vary in shade from pure white to lavender, mauve, pink, rose, salmon, blue, and purple. The Cup and Saucer variety is known as $C$. calycanthema. All these varieties are biennials, and the seed should be sown in the spring or early summer. It is not worth while to buy seeds of all the varieties, for if you purchase the most expensive, $C$. calycanthema, you will find that the flowers will be mainly ordinary singles and doubles. It is as a general thing wise to buy the choicest varieties of most seeds in quantity, and you will find that you have got more than you need of the commoner sorts. The only way you can get the shapes and colors you prefer is to mark your best plants and collect the seeds from them. To be in any way certain even then, you must take care to remove other plants of a different shape or color from the neighborhood of your chosen variety. The medium Campanulas do well in ordinary garden soil ; prefer sunlight to shade, and are easily transplanted. They bloom on the island from July I 2 th to September I 5 th. 


\section{PERENNIALS AND BIENNIALS}

Our next choice among hardy perennials would be the Delphiniums, or Larkspurs. There are a number of species, and a large number of varieties of hybrid sorts. D. grandiforum, called also $D$. Chinense, and $D$. Sinense, grows to a height of two or three feet with flowers of a deep blue. D. Cashmerianum is said to grow from fifteen inches to two feet in height, but I have plants which reach to quite three feet. The flower is large, and of a charming shade of azure blue. D. elatum, the BeE LARKsPUR, is the tallest member of the family, and six feet is given as its maximum, but one of our plants on the terrace annually reaches a height of over ten feet. $D$. formosum, a variety of which is called $D$. cheilanthum, grows from three to five feet high, bearing rich dark blue flowers, tinged with purple with a white eye. There is a species from California, known as $D$. nudicaule, which grows to a height of from two to four feet, with scarlet or yellow flowers. D. elatius is a tall variety of $D$. nudicaule, and there is apparently not enough difference between the latter and $D$. cardinale to justify the creation of a new species. So, too, D. Zalil is probably the yellow variety of $D$. nudicaule, though on these points there is much confusion. 


\section{AND THE WILDERNESS BLOSSOMED}

All varieties of perennial Larkspur seem to require a well-drained locality, and are said to do best in a rich soil. The tallest, sturdiest plant we have has certainly not got more than nine inches of soil on top of the bed of broken stone on which it rests. The period of the bloom of Larkspur, like many other perennials, may be protracted by cutting back the stalks as soon as they have finished flowering. So a bird, if its eggs are stolen, will build another nest, and lay another set of eggs. Does the flower know that its seeds have been destroyed, as the bird knows it? The Larkspur may be increased by dividing the roots in spring, and this should be done in any event every few years. They are apparently hard to raise from seed. I have bought the seeds of $D$. nudicaule again and again, and planted them with the greatest of care, but not a single seed has ever germinated. They seem to lose their vitality if kept for any length of time, but I have had fair fortune in raising plants from seeds planted as soon as they were ripe. The Larkspur blooms on the island from July Ist to August roth.

The Hollyhock, Althea rosea, is a superb plant in the garden, the flowers being single, 


\section{PERENNIALS AND BIENNIALS}

double, and semi-double, and ranging in color from white to almost black, including every conceivable shade of rose, red, lavender, purple, and yellow. The choicest, to my taste, are the large semi-double strains with fringed petals. Every seedsman seems to have his own distinctive name for this variety. One calls it "Mammoth Flower," another "Mammoth Fringed Allegheny," while with a third it is simply "Allegheny," but, whatever the name, it is the best. A distinct dwarf species is the Japanese, or Tokio. Some dealers, probably because it is new, declare that this species is "superior to all others." Don't believe a word of it. It is not worth growing, except by those who crave novelty at the sacrifice of all else. The plant is low, bears but few flowers; the range of color is limited, and every shade bad. The dealers tell you that "it possesses odd tints, peculiar only to this variety." Fortunately for the other varieties, this is quite true, as the only shades I have seen are a horrible maroon, or Solferino, and a soiled yellow. Hollyhocks may be readily raised from seed, as the seeds germinate well, even if several years old, and the young plants are easily transplanted, if moved before they grow large. The 


\section{AND THE WILDERNESS BLOSSOMED}

root stalk is very long, and even in young plants it requires something like a crow-bar to get a hole deep enough for their accommodation. The Hollyhock is a puzzling plant as far as its hardiness is concerned. Old plants die under the most favorable circumstances, and live when almost any plant would be justified in giving up the struggle. I have seen a plant half projecting from a snow-drift in the latter part of May, and looking green and healthy as it waited for its other half to be uncovered. I gather the best seeds from the choicest plants, and always raise a few new plants every year. You may as well make up your mind in advance to treat the Hollyhock as a biennial. If you do this, you will be pleased now and then to find that some favorite plant has survived the winter, but if you treat it as a perennial you will be continually disappointed. The plants should be staked up early, so that they may not be prostrated by storms. Good galvanized-iron stakes are the best, as well as the cheapest, for they never break or wear out, and it is well to see to it that they are tall enough to be serviceable, as this plant often attains a height of twelve feet. The Hollyhock requires a deep rich soil to do its best, with 


\section{PERENNIALS AND BIENNIALS}

plenty of water in dry weather. If a few large flowers are what you desire, you must thin out the spikes, cut off the side shoots, and sacrifice half the buds on the remaining stalks. If you simply desire profuse bloom, let them alone, and give the plants plenty of liquid manure at intervals. I transplant my Hollyhocks into a long bed two feet or so apart, doing this work in the early spring, and then drop a seed or two of some choice variety into the spaces between the plants. This assures us bloom the following year if the old plants die. The Hollyhock begins to bloom on the island about July 2oth, and continues until frost. The single varieties are invariably the first to bloom, and the whole bed is at its best about the middle of August.

Myosotis, or Forget-ME-Not, ought to be much higher up on the list than this, but I hardly know what to displace to make room for it. There are several varieties in cultivation. $M$. palustris, a common wild flower in Great Britain, bears flowers which, though generally blue, are sometimes white. A variety of this species from its long period of bloom is known as semperflorens. $M$. alpestris, a dwarf variety of $M$. sylvatica, is 10 


\section{AND THE WILDERNESS BLOSSOMED}

an Alpine species of varied coloring, ranging from deep blue to rose and white, and of course the seedsmen make several species out of it. $M$. sylvatica is a British species that grows well in the woods, though palustris and alpestris have found their way into the woods on the island, and thrive there. John Burroughs tells of a dwarf species which he found growing at Plover Bay on the coast of Siberia in 1899. He says : "The prettiest flower we found was a low Forget-meNot, scarcely an inch high, of deep ultramarine blue, - the deepest, most intense blue I ever saw in a wild flower." Possibly this plant may be $M$. Rehsteineri; but I have never seen it, and the descriptions are too vague to decide the question certainly. Such a plant would be a valuable addition to our hardy spring bloomers. The seed of the Forget-me-Not should be sown in early summer. It may be scattered broadcast where the plants are to bloom, or planted in drills in the garden beds and then transplanted. I adopt both methods, as I can always find a place for this charming flower. It blooms from the first to the end of June and scantily in shady spots through July.

Here, again, is the Ickland Poppy, Papaver 146 


\section{PERENNIAĹS AND BIENNIALS}

nudicaule, which certainly should not be so far down on our list of choice hardy perennials. As its name indicates, this poppy is a cold-weather flower, and it is not likely to do well in warm regions, as the heat of a southern summer would be sure to kill it. On the island it vies with the Pansy in the race for the first blossom of spring. I have had it in bloom as early as May 26th, but it is not at its best until about the $7^{\text {th }}$ of June. It continues to bloom profusely until about the Ioth of July, but we can always find some plants in bloom throughout the whole season, from the melting of the snow to the coming of the frost. When at its best, these small, robust plants are covered with blossoms. It seems to do well in most situations, if not too shady; and with me it has done best on the southern slopes in full sunlight. Though the color of the flower is usually yellow, you will find many white and deep orange blossoms, with now and then a semi-double specimen in any of these colors. The seed is easily gathered and cleaned, and should not be planted later than midsummer, that you may get hardy plants before cold weather. You can buy all the colors separately from the seedsmen, but at the same time you need not ex- 


\section{AND THE WILDERNESS BLOSSOMED}

pect the colors to come true. I advise you therefore to buy simply the mixed seeds, for in them you will find all the colors. Thereafter, if you desire, you can keep the colors separate when you gather your seed; like the seeds you buy, however, you will find that they will not always come true, but show a constant tendency to produce yellow flowers.

The Oriental Poppy, Papaver orientale, is by all odds the most showy perennial one can have. The single flowers of brilliant scarlet on long stems are most effective. The flowers often attain a diameter of nine inches or more. A variety, bracteatum, bears the largest flowers, each of the four petals being marked with a black spot at the base. Some hybrid forms have been produced with pinkish or salmon blossoms. Seeds from the latter, however, have always produced scarlet flowering plants for me. This plant is easily raised from seed, which should be sown early in July, and the fresher the seed is the better. It is easily transplanted, if the plants are taken up when quite young. It blooms on the island from about the 2oth of June to the Ioth of July, and sparingly for a week or so later, its short period of flowering being its only defect. Before 


\section{PERENNIALS AND BIENNIALS}

blooming the bright green foliage of the plant is most attractive.

The Lily-of-The-V Alley, Convallaria majalis, is simply an indispensable adjunct to the flowergarden. It has been moved to a dozen different spots on the island, but at last has come to rest on a southern exposure in partial shade, with some degree of moisture in the soil. Here it has done admirably, increasing the number of its plants and also the size of its flowers, with very little care or attention. I planted the crowns separately five or six inches apart, which gave ample room for spreading; and I did this in September, though all the authorities agreed in insisting that this work should be done "late in autumn or during the winter months with open weather." I did not find, however, that the plants in any way resisted removal at this earlier period, or were any the worse for it afterwards. The bed will be improved by a top dressing of manure in the fall. It blooms with us from May 25th to June $25^{\text {th. }}$

Phlox is a purely American genus. Gray gives eleven species, all of which are perennials, excepting only the well-known $P$. Drummondii. Of the three species commonly seen in gardens, the tall 


\section{AND THE - WILDERNESS BLOSSOMED}

late-blooming $P$. paniculata, generally referred to in the catalogues as $P$. decussata, is probably the most familiar. It grows from three to four feet in height, and in some localities reaches quite five feet. The colors have been varied largely by hybridization, and there are many named varieties. The original color of the type was a pinkpurple, with a white variety. Now we are able to get these fine flowers in shades of scarlet, salmon, crimson, lilac, violet, rosy-mauve, purple, pure white, and a large number of plants with these colors mixed and blended in bewildering profusion. The plant is easy of cultivation, needs little attention, and a bed once established will last for several years. It may be reproduced by dividing the roots in spring, or from seed. In the latter case the seed must be planted as soon as possible after ripening, for if kept over till spring it is quite worthless. Do the seedsmen know this? They certainly offer the seeds for sale at all times in the year. It blooms on the island from August ist until frost.

Closely akin to the above is the $P$. maculata, which is generally referred to as $P$. suffruticosa. This species is not so tall as the late-blooming variety, rarely exceeding two feet, but its flowers 


\section{PERENNIALS AND BIENNIALS}

are quite as attractive, and it begins to bloom as early as the $15^{\text {th }}$ of June. In this case also there are a large number of named varieties. Its cultivation is the same as that of $P$. paniculata.

Phlox subulata, the Moss Prnk, has little resemblance to its tall and stately brethren. Its foliage is moss-like, and its delicate branches, lying prostrate on the ground, bear pinkish-purple flowers in profusion, almost hiding the foliage. It is a true mountain plant, and rejoices in a home on some rocky ledge. A variety bears a white flower, making the ledge in spring look like a drift of belated snow. I have never tried to raise this plant from seed, but bought the plants themselves, increasing them by cuttings, which quickly take root. It is one of the very best plants for rock work, blooming on the island from June $15^{\text {th }}$ to July $24^{\text {th. }}$. There are a number of varieties of this species, among them being $P$. frondosa, with rose-colored flowers; $P$. nivalis, white; $P . N e l s o n i$, white with pink eye; and many others.

Phlox reptans, $P$. verna, or $P$. stolonifer a spreads by long runners which send up straight stems six inches high, bearing clusters of from six to eight rosy-red flowers, three-fourths of an inch across. 


\section{AND THE WILDERNESS BLOSSOMED}

It is perfectly hardy, and grows well in a rocky border in light soils. It blooms a little later than P. subulata.

Monarda didyma, Oswego Tea, Bee Balm, or Fragrant $B_{A L M}$, is of the Mint family, and is a most desirable acquisition. In a favorable location it grows to a height of four feet, bearing upon its stems bright red flowers, which remain in bloom from July Ioth to September I2th. I have tried raising it from seed, but with little success. It is, however, so easily divided at the roots that it is a waste of time to bother with the seeds. One plant at the end of the first season was divided into seven, and the following year each of the seven was capable of almost as extensive a division. To-day I have probably a thousand of these plants, all in good condition, which have come directly from the same parent stem. They look by far the best in masses, and I find that although they will live in partial shade, they do best in full sunshine. One of the odd features of this flower is its tendency to continue its stem through the corolla, and at the height of an inch or two producing a second blossom, and in some cases even a third appears, making a flower three stories high. A near relative is $M$. fistulosa, or 


\section{PERENNIALS AND BIENNIALS}

Wild Bergamot, with flowers varying in color from rose to purple and white. I have tried none of this genus but didyma, but that I cordially commend.

Pyrethrum roseum, - Chrysanthemum coccineum, as properly it should be called, - or FEvERFEw, is a handsome flower which comes to us from the Caucasus, and is there the source of the Persian Insect Powder. It is easily raised from seed, is perfectly hardy, and a profuse bloomer, its bright red daisy-like flowers being an ornament to the garden and to the table as well. The seeds are easily collected, and may be sown in the spring or the late summer. By careful selection the color has been greatly increased in range, and we can now get varieties in white, white with yellow centre, purple, crimson, carmine, red, pink, lilac, and rose. It blooms from June 2oth to July $25^{\text {th. }}$

Campanula carpatica, or Car Pathian Harebell, is one of the most desirable of the campanulas after the medium varieties. It bears well up above the foliage numerous cup-shaped flowers, on stems ten inches or more long. The original color is a light blue, but varieties have been produced of a still paler blue and white. It bears an abun- 


\section{AND THE WILDERNESS BLOSSOMED}

dance of seed, a little tedious to gather; but as the seeds are small a modest quantity will be all that you will need to keep up the species in your garden. It blooms profusely from July $5^{\text {th till }}$ August Ist, and sparingly as late as September.

C. glomerata grows about eighteen inches high, and bears clusters of rich dark purplish-blue flowers, from the rgth of July to the Ist of August. It is good for cutting and decoration, and is an attractive feature in the garden. I have not succeeded in raising it from seed.

C.pyramidalis, $\mathrm{C}_{\text {himney }}$ Campanula, or Steeple BELLFLowER, is the tallest of the genus, growing in favorable localities to a height of six feet. The flowers are generally blue, though there is a white variety, and the bloom continuous for nearly two months in summer. It is not difficult to raise from seed, and this should be done yearly, as the plant is apt to die out after blooming once or twice. Indeed, all varieties of Camyanula ought to be treated as biennials, and a few plants raisęd every year, if you would keep up the supply. The seed does best with me when planted in the spring.

C. latifolia grows to a height of two feet or more, bearing small blue tubular-shaped flowers. 


\section{PERENNIALS AND BIENNIALS}

It blooms for six weeks and more in summer, is very hardy, and its seeds will soon fill its own bed with plants, and invade others fifty feet or more away.

Dianthus plumarius, the old-fashioned GARDEN or Scotch Pink, needs no description. Some of the varieties are not hardy enough to stand the cold winters on the island, and among them is the so-called "Hardy Pink Her Majesty." It will not live there, and, indeed I have had no success at all with plants or seeds of any of the varieties so highly praised. All on the island have been raised of late years from seed gathered there. I set the plants one foot apart, and then plant seeds in the spaces between them. The following year I repeat this operation at another spot. This ought to insure constant bloom, but it does not always do so, and every now and then we have a year almost devoid of pink blossoms, though the plants seem to be large and healthy and able to bear flowers if they would. Its bloom begins on the island June $15^{\text {th }}$, continuing to August Ist. The seeds are not hard to collect, but as nature intended to drop them gradually, and not all at once, you will find that they may be dislodged much easier if the pods be allowed to ripen thor- 


\section{AND THE WILDERNESS BLOSSOMED}

oughly by remaining for a week or two in a box with a free circulation of air, and in the sun for a time each day. To pull each separate pod apart and pick the seeds out would be found very tedious, and you would get many unripe seeds in this way.

There are a large number of lilies offered by the seedsmen, many of which are said to be perfectly hardy. My list of successes is but a brief one, but there is no doubt that it may be materially increased by further experiment. The best of all is undoubtedly Lilium auratum, the GoLDENBANDED LiLy of Japan. The flowers are large, blooming profusely on well-established plants, and deliciously scented. On the island it blooms from August $5^{\text {th }}$ to September 1 oth, and in my experience it is perfectly hardy. I planted the bulbs in two localities, one group being on the terraces in full sunshine, in a well-drained soil, through which water from the rocky ledges percolates during the summer. The others are on the top of the hill, on the edges of a clump of rosebushes and flowering shrubs. In the latter place the plants grow scarcely more than three feet high, and the flowers, though comparatively few in number, are of enormous size. On the 


\section{PERENNIALS AND BIENNIALS}

terrace, on the other hand, the plants sometimes reach a height of ten feet, bearing large numbers of flowers, though the blossoms themselves are much smaller than those in the other bed. I have never attempted to reproduce this lily from seed.

Lilium tigrinum, the well-known TIGER LILY, needs no description. It is easy of cultivation, thrives in almost any situation, but likes deep sandy loam, and is perfectly hardy, blooming from August 2oth to September 15th. There are a number of varieties, the double variety, splendens, being tall and showy. It is easily reproduced from the bulbels which form in the axils of the leaves. These bulbels should be planted just as they begin to sprout and are ready to fall to the ground. I have surrounded a single stalk with numerous younger plants by simply cutting the bed a little larger each fall, and pressing the bulbels into the soil. I have also raised a number of good plants in the garden beds, transplanting them after they were a foot high. In this way I have obtained sturdy blooming plants in two or three years.

Lilium tenuifolium, the Siberian Coral Lily, is a treasure in a cool climate. Ordinarily it grows 


\section{AND THE WILDERNESS BLOSSOMED}

about eighteen inches in height, but I have had plants three feet high, covered with the daintiest wax-like little lilies of intense scarlet. It blooms early in the summer, and bears quantities of seed in its pods. These seeds germinate freely if planted either in September or in the following spring, and from them you may obtain blooming plants in two years.

Lilium speciosum and its varieties, as well as $L$. longiflorum, I have tried; but so far my experience leads me to fear that none are hardy enough to survive our cold winters and late springs in Maine. L. candidum has persistently died for me in the past, after a single season's bloom, but I hope still to get it acclimated when I find just the right spot. L. croceum ought also to do well on the island, but so far I have not been successful with it.

Hemerocallis flava, the Yellow DAY LILY, is a very desirable plant. The bright lily-like flowers, deliciously fragrant, are most attractive on the lawn and are also good for cutting, lasting a long time in water. I have had the best results with this plant on low ground near the water. The seeds are easily gathered, being large, and the plants are by no means difficult 


\section{PERENNIALS AND BIENNIALS}

to raise. The seeds germinate freely, whether planted in the fall or the following spring. There are several other species, and among them may be noted $H$. fulva, which is taller than the former, and bears copper-colored flowers; $H$. middendorfi, a Siberian species, with goldenyellow flowers; and $H$. minor, with grass-like leaves, comes also from Siberia.

On one occasion attracted by a dealer's advertisement of a White DAy LILY, I ordered a dozen plants, only to find that I had received a consignment of Funkia, the Plantain Lily, for which I really did not care at all. You cannot always order by familiar names and be sure of getting what you want. Thus, if you order a plant of Woodbine, you may get either the Virginia Creeper or a Honeysuckle. When the late lamented Colonel James Fisk, Jr. told the court, on cross-examination, that the money of the Erie Railroad had "gone where the woodbine twineth," no one knew whether he referred to Lonicera Periclymenum or Ampelopsis quinquefolia, the former of which a dealer describes as "Common Woodbine," and the latter is characterized by the same authority as "Our Well-known Woodbine." It is undoubtedly true, however, that 


\section{AND THE WILDERNESS BLOSSOMED}

both species will go "up the spout" when opportunity offers, and that was where the money went.

As, above all things else, I like profusion in the flower world, I confess to a fondness for Malva moschata, the Musk Mallow. It is such a happy, contented plant, and not at all particular whether it grows in sunshine or shade, but quite satisfied if you will only let it alone. Root it from the garden bed, and it will spring up in the path. Cut it down with the hoe, and it will creep in amongst the gooseberry bushes, and, defended by their prickly stems, it will bloom there abundantly. It grows about two feet high, and is crowded with white or rosecolored blossoms, two inches in diameter, blooming from June 26th to August 20th. It is generous in the production of seeds, which are prevented from falling too early by the stickiness of the hull. You can leave the collection of the seeds until the plant is well dried, when they are easily shaken out.

Dicentra spectabilis, the well-known BleEding Heart, needs no description. It is perfectly hardy, blooming from the 8th till the 2oth of June. The rootlets should be planted in the I60 


\section{PERENNIALS AND BIENNIALS}

autumn, though on one occasion a belated bundle of bulbs and roots remained unpacked all winter, and the Bleeding Heart portion all survived the experience, though they did not bloom the first year. I have never been able to get the seed, though some of my plants have cast their own seeds to a considerable distance, to grow and thrive in a stump-corner devoted to climbing Nasturtiums. The proper method of increasing the stock is to take up the roots in the fall and divide them.

Dielytra is said to be a name erroneously given to Dicentra. If this be so, why not drop it once for all? Yet we see it constantly used in the catalogues and even in books on botany. I remember once Steve Hubeley, my then head gardener, asked me whether that Bleeding Heart up by the house was the same as that down by the wharf, and upon my telling him that it was, he remarked with evident relief, "I thought it was, but that one down by the wharf has a terrible comical name on it." And some of our botanical names may well be called comical.

I wish I were able to report better success with Roses in this cold climate. I have set out scores of so-called hardy varieties, and though 


\section{AND THE WILDERNESS BLOSSOMED}

many are still alive, only three species look comfortable and contented. Of these the best undoubtedly is Rosa rugosa, the familiar Japanese rose. When well grown, they form round, shapely bushes; fully five feet or more high, covered with deep green foliage so glossy as to suggest the possibility of their being covered with varnish. It bears in profusion large single roses, which are succeeded in the fall by the brilliant scarlet fruit, as large as a queen olive. If this bush bore no flower or fruit, it would still be a valuable acquisition on the lawn from the beauty of its foliage. There are two varieties, one bearing red and the other white flowers. Of the two, I prefer the white, but I would not willingly be without either of them. It blooms profusely from about June 20 th to July i 8 th, and sparingly thereafter until September. It can be reproduced from cuttings, from dividing the roots, and from seeds. The seed takes a year to germinate, but it is worth the trouble, time, and space.

Rosa rubiginosa, the SweET BRIER, is hardy enough for this latitude, and does wonderfully well. Like rugosa, it looks best on a favorable spot on the lawn where it has plenty of room to 162 


\section{PERENNIALS AND BLENNIALS}

spread on every side, and so develop the best there is in it. It blooms from the Ist to the I 5 th of July.

Rosa lucida, the dwarf WILD Rose, has been caught in the region and tamed. There is a hedge of it now on the island, more than a hundred feet long, that every year increases in the beauty of its bloom and the richness of its foliage. It blooms from June 20 th to July i 5 th.

Chrysanthemum uliginosum, the GIANT DaISY, uniformly called by the dealers a Pyrethrum, was described in such glowing terms in a catalogue, with such a tremendous picture to prove the truth of it all, that I was convinced that I could not get along with less than eighteen plants. If I had bought but one plant, and had annually divided its roots, I could to-day have covered half an acre with the product. It is a wonderful grower, thrives anywhere, and pushes to the wall every other plant in its neighborhood. It grows five or six feet high, bearing large white daisylike flowers in profusion, from the first week in September until frost.

Chrysanthemum lacustre, or latifolium, and $C$. maximum are both hardy plants, bearing large single white daisy-like flowers. They may be 


\section{AND THE WILDERNESS BLOSSOMED}

raised from seed, and bloom from August Ioth to September 15 th.

Agrostemma coronaria, or, as it is now called, Lychnis coronaria, is also known as Rose CAMPion, Mullein Lychis, Mullein Pink, and Rose of Heaven, though the latter name properly belongs to $L$. cali-rosa. It grows about three feet high, and bears numerous flowers about an inch in diameter in loose clusters. In color it ranges from a dark rose to white, with some specimens white with a crimson eye. It does well on dry banks and in full sunshine, though it is apt to die out after blooming once or twice. While it will seed itself, it is still best to gather a few seeds each fall and plant a fresh row annually in the seed beds, as the plant is well worth keeping. It blooms from July $5^{\text {th }}$ to September Ist.

Lathyrus latifolius, or Perennial PeA, is a hardy vine, worthy of attention. It is easily raised from seed, but the plants must be moved when quite small. Once established they should be allowed to remain, and they will continue to bloom for several years. They do not need a trellis, but look better, and seem more at home, if allowed to $\operatorname{climb}$ at will over a sloping rock or ledge. I64 


\section{PERENNIALS AND BIENNIALS}

The flowers are mainly red and white, though varieties in light rose, and also a darker rose, have lately been introduced. The seeds are easily gathered, and from them new plants may be raised without trouble. It blooms from July Ist to September Ioth.

The severe winters of the mountain regions of Maine make it difficult to find perennial vines which will stand the cold. Besides Lathyrus latifolius, which dies to the roots at the first frost, I know of but one vine able to live over winter in this region, that being Ampelopsis quinquefolia, Virginia Creeper, or American WoodBINE. It is a rapid grower, and easily increased by partially burying the prunings in the earth. I cover two or three buds, and permit a bud to emerge from the ground at either end. They will quickly root in this position, and the following year you will have from them good strong vines.

Some species of Iris do well here. I. prismatica, or $I$. Virginica, the native AMerican IRIs, fills the low swampy lands of the region, and in June an acre or more may be seen thickly covered with the nodding blue blossoms. It may do to fill waste spots, but it is not worthy of 


\section{AND THE WILDERNESS BLOSSOMED}

much attention. I. pseudacorus, the YELlow IRIs of Europe, is also found here sparingly, and withstands the winter. It also is not very attractive. I have had no trouble in inducing I. levigata, or Kempferi, the JAPANESE IRIs; to grow here, and $I$. Germanica, the GERMAN IRIS, or common FlEUR-DE-LIS, is equally hardy. If you would raise this plant from seed, the seed must be sown as soon as it is ripe.

Gypsophilla paniculata is perfectly hardy, and with its delicate leaves and bearing innumerable minute white blossoms, it is a valuable addition to the vase of Shirley Poppies. It blooms from July I2th to August 2oth. A lady once spying it exclaimed, "Oh, Mr. Dexter, what is that beautiful plant? Is it not called "Matrimony'?"

"No, my lady," I was forced to respond, "but doubtless it is close kin to it, as it is called Baby's Breath."

It has a long root stalk and must be transplanted when quite small. The seeds are somewhat troublesome to gather, but it will not prove a serious task to obtain all that you will need to supply possible losses.

Once when we were putting out this plant one I66 


\section{PERENNIALS AND BIENNIALS}

of the men asked me what it was. I told him that it was called "Baby's Breath," but that the proper name was Gypsophilla. Later I heard him passing this information on to the other men, and they were solemnly informed that the plant was called Baby's Breath, but that the proper name was Gypsy's Fill. But my helpers have long since passed that stage of botanical knowledge, for I always insisted upon calling my plants by their proper names, and the men were forced to increase their vocabulary.

"Now, Henry," I remember saying once, "we'll have a box full of Pyrethrum roseum from the garden."

The other men laughed, and Henry hesitated, finally asking, "Do you mean them carrot tops?" Yes, it was the "carrot tops" we wanted, and he had learned what Pyrethrum roseum was like in its youth. At the same time it is a bit annoying, after you have once learned so important a fact, to find that this is not its proper name after all, but that it should be called Chrysanthemum coccineum.

Linum narbonnense, the Perennial $\mathrm{F}_{\mathrm{LAX}}$, is as charming and delicate a flower as can be found anywhere. It is a profuse bloomer, and its sky- 


\section{AND THE WILDERNESS BLOSSOMED}

blue flowers, about an inch in diameter, look as if made of the finest porcelain. It grows to a height of nearly two feet, and remains in bloom from June 2oth to frost. It is easily raised from seed, and the plants improve with age. It is perfectly hardy.

Lupinus polyphyllus is an admirable plant in masses. Its foliage is luxuriant, and the great stalks five feet high are covered with blue or white or blue and white blossoms from June I 2 th to July 7 th, and sparingly to August ist. I have one terrace thirty feet long nearly covered with Lupins, and in the midst the Oriental Poppies raise their brilliant scarlet heads at intervals, while off at one corner is a bush-like mass of Achillea covered with its small white blossoms. The general effect is inconceivably beautiful. This terrace is at its best but a few days, however, at about the first of July, but those few days are worth working and waiting for. The Lupine is easily raised from seed, but after getting it well established, you will not need to gather more seeds, as the plant is most active in extending its rule over new soil. As the pea-like seedpod dries out, it suddenly cracks open, and the halves twist into curls, tossing the seeds in differ- 


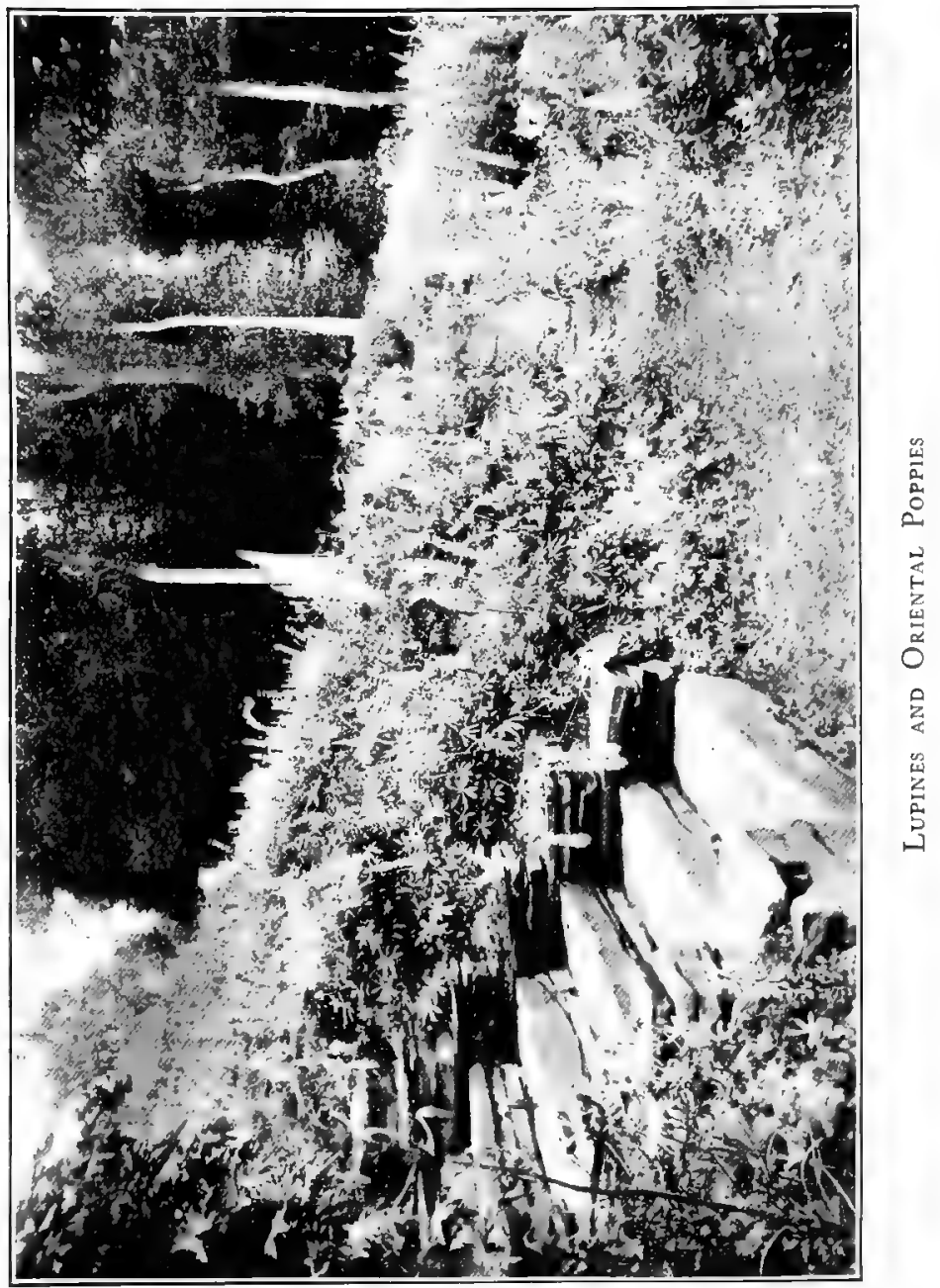





\section{PERENNIALS AND BIENNIALS}

ent directions to a considerable distance. This flower comes from the Pacific coast of North America, and is naturally acquisitive and imperialistic in its tendencies.

Bellis perennis, the English DaIsy, may not be worth much for table decoration, but it is most interesting to look at on the edges of the terrace. Its colors range from white, red, and pink to crimson, both flat-petalled and quilled, single and double. They are easily raised from seed and are perfectly hardy, blooming from June 2oth to frost. They are attractive in masses and equally so as a carpet about taller plants, such as Coreopsis, and are charming mingled with Forget-me-Nots. I sowed the seed broadcast over a bit of lawn on one occasion, and many plants appeared the following spring, sending their bright blossoms three or four inches above the ground. But one day along came the lawnmower, and every flower was laid low. Warned but not deterred by this, the next time they blossomed the stems were scarce half an inch long, holding the flowers close to the earth, and below the range of the lawn-mower's knife. I was interested in this, and therefore took up a few of these plants and removed them to a corner free 


\section{AND THE WILDERNESS BLOSSOMED}

from the danger of the mower, and lo! up went the new stems three or four inches into the air, while their brethren in the grass still continued to hold their flowers close to the earth. Do flowers think? Look at the Dock-Weed in the unused corner, and see how it sends its leaves luxuriantly a foot nearly into the air, while its stems bearing flowers and incipient seeds are taller still. Then look at another specimen in the lawn, invaded so frequently by the mower, and you will find its leaves prostrate, so close to the ground that no knife of mower can touch them, and the stalk carrying the precious seeds is scarcely an inch in height.

Man is so conceited that he will not acknowledge that any other form of life than his can reason or think, have the faculty of perception, or give expression to thought. Nonsense! All animals think, most of them talk, and some have high reasoning powers; and why. not plants? Down on the Chesapeake a winged-tipped goose is often saved alive to be used as a decoy. Anchored among the wooden cheats, he will generally see the approaching game before you do, and his "Se-Honk! Honk!" will turn the flock in your direction. Why does he call? Is it in the 


\section{PERENNIALS AND BIENNIALS}

hope of help that will loosen his bonds? Not long ago a friend of mine having broken the wing of a wild goose, saved him for a decoy. The break was a bad one, necessitating the amputation of a portion of one wing, rendering it impossible for him to ever fly again. Did he realize that? I don't know, but I do know that the first time he was used, and a flock of geese were seen coming straight to the decoys, the crippled goose never uttered a sound until just before the bunch arrived within gun-shot, and then raising his head he gave a "Honk!" with an inflection that sent the whole flock away from the point of danger as fast as they could fly. That honk evidently meant "go," not "come," and it was understood. It was always so thereafter. No goose ever came within gunshot of a blind when this lame sentinel was on guard, and in the end he was killed and eaten, a martyr to his race.

Wound a duck, and see how by flying, swimming, or diving, he will hasten to the seclusion of the marsh. Once there he proceeds to dress his wound, filling the cavity with a lint made of straw, and fine fibres to stop the bleeding and insure healing from the inside. Do you know that primitive man did no better surgery than that? 


\section{AND THE WILDERNESS BLOSSOMED}

Indeed it was precisely the same treatment that was formerly followed by man, and not so long ago either. Moreover I have seen wounds on the neck of a duck, treated in this way, in such a position that it would have been practically impossible for the wounded duck to have dressed it himself. Another must have done it for him. But are we not getting away from our flowers? I don't know that we are, for there are flowers in the wilderness other than those on stems, be they long or short.

You can have all the Preonies you want in a climate as cold as our island, and they will give you but little care or trouble. There are numerous varieties, and four distinct species in the herbaceous class. One of these, Pronia albiflora, the Chinese $\mathrm{P}$ exony, flowers later than the European species, $P$. officinalis and $P$. peregrina; so with a judicious mixture you can double the period of bloom. All these species are perfectly hardy. They delight in partial shade, and do best in a deep moist loam, their bloom being improved by an application of manure water at the budding season. When the plants grow too large, take them up in the spring, separate the roots and transplant in fresh soil. 


\section{PERENNIALS AND BIENNIALS}

With Pronia Moutan, the Tree Peony, I have had no success. I was anxious to establish this species on the island, and used great care in setting out the plants, but the first winter they all died.

Platycodon grandiforum, sometimes improperly classed as a Campanula, is a desirable plant which comes from northern Asia. It bears large Campanula-like blue or white flowers, and is easily raised from seed. It apparently dies out after blooming once or twice, and you will have to plant seeds every year if you would keep up the supply. It does well in partial shade and in any light soil, which, however, should be well drained. $P$. mariesii is a dwarf form with somewhat larger flowers. $P$. autumnale is said to be taller and more hardy, with smaller flowers, but I have not yet tried this variety.

There are a number of species of Rudbeckia, the well known Cone-Flower, all of which are hardy perennials with the exception of $R$. bicolor, a half-hardy annual. Nurserymen have offered for sale the plants of a variety of $R$. laciniata which they call Golden Glow. It grows to a height of fully eight feet, bearing numerous large golden-yellow flowers, quite double in form, and resembling the double dahlia somewhat in shape. 


\section{AND THE WILDERNESS BLOSSOMED}

It is an attractive plant, a free bloomer, and under favorable circumstances will produce fully one tenth as many flowers as may be seen in the ordinary catalogue picture. I have not yet had an opportunity to test its reproductive qualities in any way, but the plants are not expensive, and bear transportation well.

There are several varieties of Helenium, or Sneeze Weed, in cultivation, the best known being the American $H$. autumnale. It grows to a height of four or five feet, and bears numerous showy yellow flowers in September which last a long time in water. It is a good plant, easy to raise, and worth having, but it is by no means " one of the most valuable of all the hardy plants," as I have seen it described. It may be easily raised from seed, and is perfectly hardy. Other species highly commended are $H$. Bolanderi and $H$. Hoopesii, but I have had no experience with either.

Bocconia cordata, or Plume Poppy, is an interesting foliage plant which comes from China, and is therefore generally known as Bocconia Faponica. It grows fully eight feet high, and its large luxuriant leaves give it a tropical appearance. Its flowers are minute and inconspicuous, but the 


\section{PERENNIALS AND BIENNIALS}

seedsman will tell you that it "bears freely spikes two or three feet long of cream-colored flowers." It is not difficult to reproduce, either from seeds or by division; indeed, once established, "the trouble is to keep from it," as it spreads rapidly by suckers.

Callirhoe involucrata, a member of the MALLow family, grows wild in the Mississippi Valley from Minnesota to Texas. It is a prostrate little plant, spreading over a couple of feet of ground, and bearing throughout the summer and until frost numerous violet-crimson flowers about an inch and one half in diameter. It does well in partial shade or in full sunshine, and is perfectly hardy. Instead of trusting to an enormous quantity of seed for its perpetuation, as so many flowers do, each blossom produces but five seeds, and of these one appears to be invariably sterile. The pistil is divided into five segments, each terminating at the base in cup-shaped form, or more like a human hand half-closed, which holds the seed. As the stem dries and the seeds become thoroughly ripe, one of these little cups will loosen its hold on the base of the stem and springing up suddenly throw the seed to a distance of ten or fifteen feet. The sketches on 


\section{AND THE WILDERNESS BLOSSOMED}

page I 77 will show the bud, blossom, erect pistil, and its appearance when it has just cast away one of its seeds.

Arabis albida, the Rock-cress, is a valuable spring blooming plant which grows well amidst rock-work or in almost any locality. It is perfectly hardy, and on the island is covered with small white flowers from June I 5 th to July ist. It is easily grown from seeds, and can be increased from cuttings without difficulty.

Paradisea (Anthericum) liliastrum, or ST. BRUNo's LILY, sends up a stalk about two feet high with dainty little white flowers an inch long, pendent from the stem. It is easily raised from seed, and is hardy. The major variety attains a height of nearly three feet, with flowers somewhat larger than the type.

Achillea ptarmica, YARROW, or SNEEzEWORT, is another of those wholesome looking and acting plants that seem to thoroughly enjoy life. I raised a few plants from seed of the double variety, the PEARL, a few years ago, and now the only trouble it gives is to keep it within bounds and teach it its place. It grows fully three feet high, and bears from July to September a profusion of very double little flowers, three fourths of an inch in diameter. 


\section{PERENNIALS AND BIENNIALS}
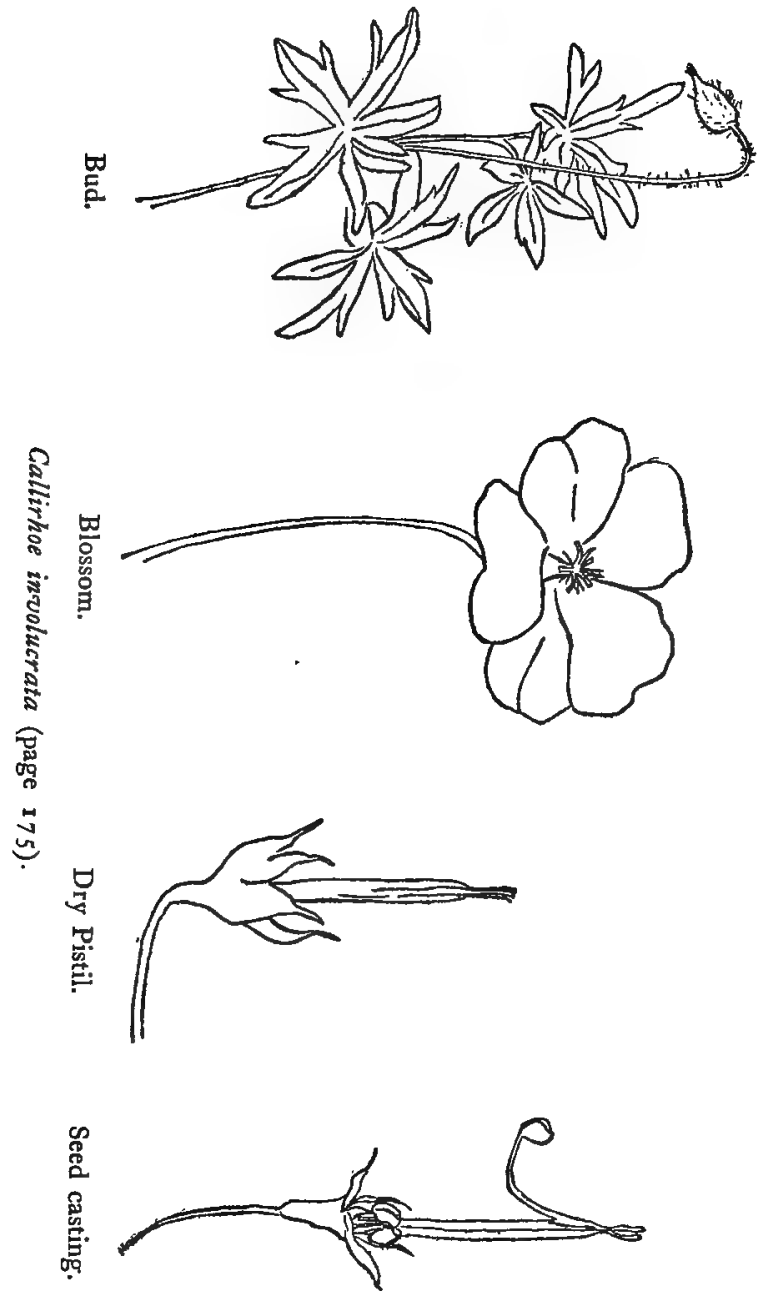


\section{AND THE WILDERNESS BLOSSOMED}

Anchusa Italica, or AlKanet, is a vigorous plant which grows three or four feet high, and bears numerous panicled racemes of small dark blue Forget-me-Not-like flowers. It blooms a long time, and a plant or two in the wild garden will not be objectionable, though why one nurseryman calls it " a very useful perennial," I cannot for the life of me determine, it being quite useless for cutting, the blossoms fading before you reach the house and refusing to revive in water.

Baptisia australis, or FALSE INDIGo, is a vigorous, hardy plant which attains a height of three feet or more, bearing racemes of dark blue Lupinelike flowers. It is easily raised from seed, and a plant or two will not come amiss in large gardens.

Polemonium ccruleum, or JACOB's LADDER, is a hardy plant with very attractive, fern-like foliage, growing three feet or more in height, and bearing in profusion small blue flowers throughout the summer. It is easily raised from seed.

Veronica spicata, or SPEEDwell, is a hardy plant three feet high which bears long spikes of small blue flowers. It is easily propagated from seed, and spreads like a weed from self-sowing.

Centaurea montana, a perennial species of CoRNFlower, known as Mountain KNapweed, is a 


\section{PERENNIALS AND BIENNIALS}

coarse and worthless plant. It can be easily raised from seed, but is not worth the trouble nor the space. The dealer who sold me the seeds originally declared in his catalogue that "for cutting purposes it is invaluable." This may be quite true, but only a hoe should be used to do the cutting.

There are various perennial species of Alyssum and Iberis, or CANDYTUFT, none of which offer any attractions to me. In all of them the bloom is quickly over, and none of them are in any way equal to the annual varieties. Like the perennial Centaurea, both Alyssum and Iberis are but shabbylooking plants when the period of bloom is over.

Some years ago a dealer described a species of $V$ aleriana in such glowing terms as $\mathrm{H}_{\mathrm{ARDY}} \mathrm{HE}_{\mathrm{E}}$ LIOTROPE, that I bought an ounce of the seed, determined to have a bank full of such a charming flower. When the plants blossomed they looked about as much like heliotrope as they did like pansies, and their odor was as rank as the seedsman's offence. The man who could dub such a plant heliotrope is a genius in a way. This name he may have invented, as I have never seen it elsewhere.

Tradescantia Virginica, or SPIDERWORT, was described in the florist's catalogue as "a showy, 


\section{AND THE WILDERNESS BLOSSOMED}

highly decorative plant, forming an erect bush producing numerous terminal umbels of large flowers, which are produced in great profusion the whole of the summer." Of course there is some truth in this statement, for the plant is erect and does produce terminal umbels of flowers, but all the rest of the description is airy persiflage. A plant or two will not be amiss, if one has plenty of room, otherwise it may properly be omitted altogether.

Enothera biennis, var. grandiflora, or EvENING Primrose, I first raised from seed several years ago, and since then $I$ have been pulling it up, whenever seen, in the vain endeavor to get rid of it. It is odd enough to justify a plant or two in a large garden, but as it is a biennial, casting ever a bountiful supply of seed, one is either compelled to get rid of it altogether or else permit it to overrun the entire garden.

Anthemis tinctoria, Golden Marguerite, or Chamomile, is a hardy plant growing three feet high, and bearing small daisy-like yellow flowers. In itself it is by no means bad, having some merit, but with so many other plants available bearing handsome yellow flowers, it seems to me hardly worth cultivating. 


\section{PERENNIALS AND BIENNIALS}

I do not consider the purple blossoms of Lunaria annua or biennis, HoNesty, beautiful. The odd flat seed-pods that appear in the fall are sufficiently curious, however, to admit the plant to the edges of the open woods. As long as it is content to remain there, well and good, but it must keep out of the garden and off of the terraces. It is easily raised from seed.

Several years ago I planted a big root of $Y_{\text {ucca }}$ filamentosa, and the first year its leaves were a foot high. Since then it has annually appeared and grown a foot high, but it has never done anything else. I am willing to wait for it to make up its mind either to die or to go to work.

I have done my best to induce different varieties of Violet, Viola odorata, to grow on the island, but the seeds uniformly refuse to germinate, and some dozens of plants described as hardy all died the first winter.

About I 893 seedsmen vied with each other in extravagant praise of Centrosema grandiflora, or BuTTERfly PeA, declaring it to be " a perfectly hardy perennial vine of rare beauty, which blossoms in July from seed sown in April, the plants growing from six to eight feet in a single season, bearing in great profusion pea-shaped flowers two and 


\section{AND THE WILDERNESS BLOSSOMED}

one half inches across." As far as my experience goes it is not hardy, and is a worthless because impossible plant in northern regions. None of my plants reached a greater height than three inches, the balance of the eight feet never materializing, and the first dash of frost tumbled down the feeble three inches. I tried these seeds for three successive years with the same result. Little has been said of this plant lately by the seedsmen, but a few individuals, who doubtless still have some of the stock of this novelty left on their hands, continue to quote it in their catalogues. It is a common weed in the sandy woods of Maryland and Virginia and farther south, and has been known to botanists for a century.

For fully ten years past I have tried carefully every variety of CARNATION which the dealers have certified to be hardy, but thus far with no satisfactory results. The last variety I tried was known as the Hardy Garden Carnation, and during the first winter every plant died. The second year a few of the plants survived, but the bloom was scanty, and, while I purpose to give this variety a still further trial, I cannot say at the present time that I know of a satisfactory 


\section{PERENNIALS AND BIENNIALS}

carnation hardy enough to withstand the winters of northern Maine.

I have also tried two or three species of Helianthus, or perennial Sunflower, under the most favorable conditions, but none have survived the winter. This flower is most attractive, and I regret my inability to make it feel at home under six feet of snow, but some flowers, like some people, are very particular.

Here our consideration of the perennials and biennials on the island properly ends; but while it is not my intention to describe the wild flowers of the region, there are certain species susceptible of cultivation, to which I must refer briefly. There is no more beautiful flower growing wild in northern Maine than Linnea borealis, the Twin Flower. The genus was named after the great naturalist Linnæus, and this flower was said to be his favorite. If you will look at the engraving of a well-known portrait of the naturalist, you will see that he holds in his hand a sprig of the Twin Flower. Miss Alice Lounsberry, in her charming "Guide to the Wild Flowers," tells this story of Linnæus :-

" A friend gathering a small flower on the shore of a Swedish lake asked the great botanist if it were $L$. borealis. 


\section{AND THE WILDERNESS BLOSSOMED}

“' Nay,' said the philosopher, 'she lives not here, but in the middle of our largest woods. She clings with her little arms to the moss, and seems to resist very gently if you force her from it. She has a complexion like the milk-maid; and oh! she is very, very sweet and agreeable." "

It is, as its specific name indicates, a northern plant, rarely found in America south of Maine, except at a high elevation, but common far north in the British Provinces. It appears to extend around the globe, bordering the Arctic Circle in Europe, Asia, and America. In Europe it is found as far south as the mountains of Scotland. It is a low, creeping plant, bearing slender stalks, about two inches high, from the top of which are suspended two trumpet-shaped pinkish-white blossoms about the size of the bloom of the Lily-of-the-Valley, but much more delicate. It is deliciously fragrant, blooming in June, underneath the trees and ferns, in moist, mossy localities, and there it spreads freely, forming a dense carpet. It is not difficult to transplant, and if given a cool, shady spot it could doubtless be grown much further south.

The Trillium, Wood-Lily, Three-leaved Nightshade, Wake-Robin, or Birthroot, is 184 


\section{PERENNIALS AND BIENNIALS}

one of the most widely distributed of American flowers. In one species or another it is found from Florida to Labrador, and from the Atlantic to the Pacific, especially northward on the west coast. In Maine the species ordinarily met with are $T$. cernum, bearing a small white flower; $T$. erectum, with an ill-scented purple flower; $T$. erythrocarpum, or Painted TRIllium, white with purple stripes, and $T$. grandiflorum, the finest of all, with a large pure white flower. The Trilliums bloom in early spring, which on the island is in June. The bulbs are easily transplanted, but they should be moved in late summer or early fall when dormant. They require partial shade and a light loamy soil.

Cornus Canadensis, the BunchberRy, or Dwarf CoRnel, is a species of dwarf Dogwood, growing wild in northern Asia and America. Its true flowers are small, but the large white bracts make a beautiful effect in June, to be followed in the fall with brilliant red berries in little bunches. It grows in moist shady spots, being about five or six inches high. It is easy to transplant, and I have it growing on the edges of the rocks amongst mosses and ferns.

Three plants of special interest thrive on the 185 


\section{AND THE WILDERNESS BLOSSOMED}

island to a superlative degree, all being eminently useful, if not ornamental. The first is Asperula odorata, the SweEt WoodrufF of old Errgland and the foundation of the Mai-trank of Germany. The young sprigs are gathered in spring and placed in a good-sized punch-bowl, when a bottle of Rhine wine is poured over them. The leaves are allowed to steep for twenty-four hours, when a second or third bottle of wine is added, with sugar to the taste and a single block of ice. When cool enough, we will, if you please, gather around the bowl. $A$. odorata does not grow wild in America, and is not often found in gardens. There is, however, a plant which has some resemblance to it, Galium trifolium, and this the German-American in his innocence often gathers for the Meisterwurz. Mr. F. V. Coville, the Botanist of the Agricultural Department at Washington, once told me that he had on several occasions been called upon to identify the Galium trifolium, and that the parties seeking the information were invariably of German descent, and he could not understand at first the interest of these people in this particular plant. When the use to which Asperula odorata was put was explained to him, the solution of the puzzle was not difficult. 


\section{PERENNIALS AND BIENNIALS}

I failed completely in attempting to raise this plant from seed, and none of the nurserymen being able to supply the plant itself, I was almost in despair, when Mr. Coville managed to get for me a few of the roots from a personal friend, and these were planted in a shady spot on the edge of the woods, where they have done admirably. I have increased their numbers materially by division, and this attractive little stranger now seems firmly established in prohibition Maine.

I will not attempt to give a scientific account of the species of mint which grows in a luxuriant bed on the low ground near the wharf. Its parents came in a cigar-box from the neighborhood of Richmond, Virginia, and such a plant needs no scientific pedigree, it being, beyond dispute, an honored member of one of the first families of Virginia. To describe the uses to which its tender leaves may be put in the spring and early summer, would be but a thankless task, for none but a true Virginian has ever penetrated its deeper mysteries.

Perched high on the edge of a rocky ledge is another plant of great interest to the serious student of nature, Tanacetum vulgare, or TANsy. How its tender, fern-like leaves may add to the 


\section{AND THE WILDERNESS BLOSSOMED}

comfort of mankind it would be useless for me to attempt to explain here, but if the intelligent reader in search of knowledge will call at the island about the hour of noon, upon any day between June and October, I shall be charmed to give him (or her) an illustrated lecture upon the uses of Tanacetum vulgare. 


\title{
CHAPTER VII
}

\author{
ANNUALS \\ "Our little life is rounded with a sleep."
}

TF I were compelled to choose for cultivation one flower only from the list of annuals, I would without hesitation select the Poppy. The seedsmen have done, and still are doing, all in their power, apparently, to confuse the flowergrower in regard to this genus, and their lists are filled with fanciful names of species and varieties to such an extent that it is often impossible for one to know what he will get when he buys the seed. Let me do what I can to unravel the snarl.

Papaver somniferum, the OPIUM PoPPy of the East, is a well-recognized species, and is not easily mistaken for any other in cultivation. The plants are generally taller than any other species, and are invariably heavier in stalk and thicker in leaf. The leaves are smooth, wavy, of a more bluish green than any other species, and are what 


\section{AND THE WILDERNESS BLOSSOMED}

is termed glaucous, that is, covered with a fine white wax-like powder that will rub off on the hand, as is the case with the skin of the fresh plum or the leaf of a cabbage. The seed-pod is very large, sometimes nearly as big as an ordinary hen's egg, and is short oblong in shape. The seeds themselves are much larger than those of any other species. The flowers are large, with a great variety in color, and are single, double, or semi-double. There are two forms of the double Opium Poppy, $P$. Murselli and $P$. paony-flowered. P. Murselli is almost invariably referred to in America as the Carnation-flowered Poppy, which is erroneous, the name having been previously applied to the double form of $P$. Rhoeas. P. Murselli-or Carnation-flowered, if you will - has very double flowers with fringed petals. The dealers advertise endless named varieties. In this class we find such names as Eiderdown, White-Swan, and Snow-Drift. Now all of these are actually the same flower, a double white Somniferum Poppy with fringed petals. What possible object can there be in giving it three distinct names? The advertiser of a large general store was once requested by the head of a department to write a paragraph 
upon some collars. After careful questioning, this is what he wrote:-

"An uneasy man at the Market Street end of the middle aisle has picked up half a dozen sorts of gentlemen's collars, had new names stamped on them inside, and wants us to say that those collars are nowhere else to be got, and that they can be got there two for a quarter."

It is needless to say that the head of the house drew his blue pencil through this paragraph.

Other named varieties in this class are FAIRY Blush, which is white tipped with rose, and Mikado, white tipped with crimson. If you buy a package of either, you are nearly sure to get plants bearing flowers of both these colorings.

The pæony-flowered class is well named. Its round balls of bloom with broad petals bear a close resemblance to the familiar Pæony, and the flowers often rival it in size. Among the named varieties may be mentioned SNow-BALL and LADY-IN-White (the same flower again, simply a double white), CRIMson KIng, Rosy Morn, Firebrand, American Flag, Lavender Beauty, Eldorado, and Black Knight. Among the named varieties of single somniferum 


\section{AND THE WILDERNESS BLOSSOMED}

Poppies may be noted the BrIDE, pure white, Empress of China, white with scarlet margins, and Danebrog, or Danish Flag, scarlet with a white cross in the centre.

You may expect to raise single or semi-double flowers from the seeds of any of the double varieties, generally, however, following the parent closely in the matter of color. You may gather and plant the seeds of a single Poppy of this species, and environment may cause it to produce remarkably double flowers. If your plants are too close together in your beds, or if for any other reason they are not sufficiently nourished, you may expect to raise only small single or semi-double flowers, while on the other hand, if you give your plants plenty of space and ample nourishment, you can produce large and very double flowers.

From the seeds of a plant that bore large single flowers with blackish-purple base, shading to mauve and edged with salmon, I raised in a single season large and very double Pæony-flowered blossoms, exactly like the parent in color. From the seeds of these I got both double and single forms, in the colors of the original, and also a variety in which white took the place of the 


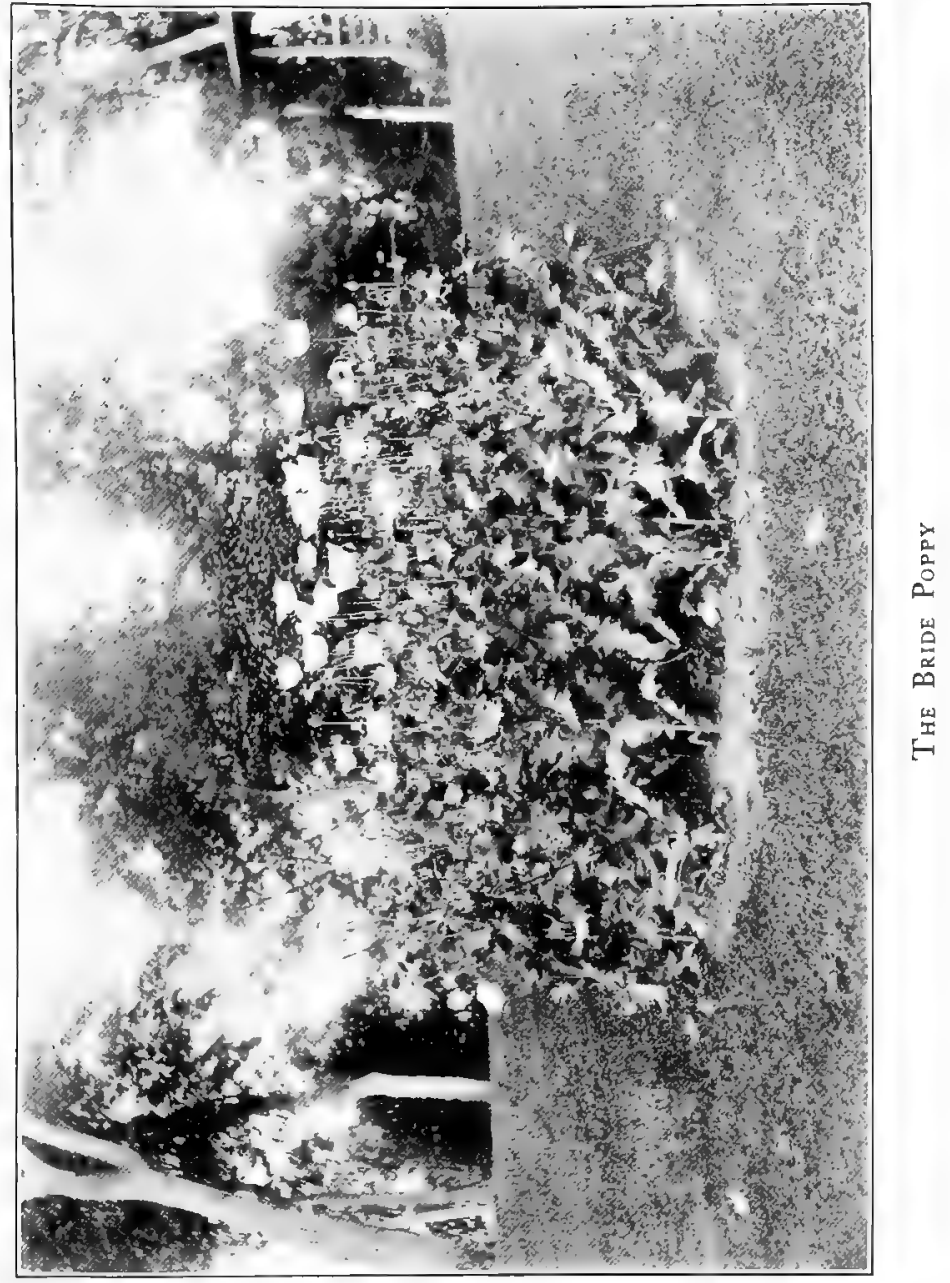





\section{ANNUALS}

dark purple. By experiment I found that from the seeds of a single flower I could produce double flowers at will, by simply giving the plants plenty of room in a favorable situation, and working in a little garden phosphate about them when they were six or eight inches high.

You will also find in the catalogues Poppy seeds offered under such names as "Maid of the Mist," "Fayal," "Oriental Beauties," and "Giganteum," with such trifling descriptions that no human being could tell to what species any of them belonged. One dealer, after offering you the seeds of Pæony and Carnation-flowered Poppies, adds thereto "Double Somniferum." It would be interesting to know what he meant by such a classification, for it presents a puzzle quite as perplexing as that submitted to a friend of mine on one occasion. His coachman came to him to ask his advice about a telegram just received. The message read, "Mother has fits. Answer." Instead of dividing the distinct species one from another in their catalogues, the dealers generally mix them all up together, and then absurdly sort them out again into single and double, so that it is quite impossible to tell whether a Poppy of a given color will prove to 


\section{AND THE WILDERNESS BLOSSOMED}

be an Opium Poppy of the East or a Corn Poppy of Europe.

Papaver Rheas, the Corn Poppy of Europe, has foliage of a more yellowish green than $P$. somniferum, with more slender stalks, and the leaves are neither smooth nor glaucous, but bristly. The pod is small, compared to the Asiatic flower, is egg-shaped, with the broad end upwards, and bears a much smaller seed. The SHIRLEY and the English Scarlet are well-known varieties of this species. The delicacy, grace, and wonderful colorings of the Shirley Poppy should have suggested to the growers the great possibilities of this strain, and encouraged them to pay more attention to the production of new shades and forms, but on the contrary they seem to have devoted their energies to the stiffer, coarser blossoms of the eastern species. All varieties of the Corn Poppy remain in bloom for a much longer period than the somniferum. The plants usually grow to a height of about two feet, but I have had specimens that exceeded four feet. The flowers are either single or semi-double, never approaching the round ball-like flowers of the double somniferum. The double form of the Corn Poppy is known in Europe as Ranun194 
culus, or Carnation-flowered. The flowers usually grow to a diameter of three and one-half or four inches, and under favorable circumstances will exceed five inches. The single forms are invariably the larger, the double rarely exceeding a diameter of three and one-half inches. The bestknown variety of this species is the Shirley, and no garden flower I know of can rival it in the beauty of its coloring and the delicacy of its outlines. The colors range from a pure white to a carmine, with every conceivable shade between the two. As with other forms, the Shirley, under certain conditions, shows a tendency to become partially double. Nothing could be more beautiful than the Shirley Poppy as a decoration for the table, though the very delicacy that challenges our admiration makes its life but a brief one after cutting. The best time to gather them, or indeed any variety of Poppy, is in the early morning, before the dew is off the petals, and even then you should select the blooms that are but just opening to the sunshine.

I have tried for a couple of years past a variety advertised in admiring terms under the name of Majestic, but have finally abandoned planting it, as it appears to be only a strain of the Shirley 


\section{AND THE WILDERNESS BLOSSOMED}

class of rather less than ordinary merit, a typical seedsman's "Novelty." The Irresistible is another variety $I$ have tried, and after trying it found no difficulty in resisting it.

The English Scarlet is a thoroughly desirable acquisition. In habit of growth and size of plant and flower it does not differ from the Shirley. The flowers are a bright scarlet, and a bed of these plants is an attractive feature on the lawn, while the flowers are admirable for table decoration. It comes true from seed, but both it and the Shirley are apt to cross with each other, even if planted a considerable distance apart. By simply pulling up the Shirley plants from the English Scarlet bed, and performing a similar service for the Shirley bed, as soon as the intruders show their character, both strains may be kept measurably pure.

Papaver Hookeri, or Hooker's Early-FlowerING Poppy, is a variety distinguished mainly by its tall growth, the flowers being remarkable neither for their size nor coloring. It grows to a height of fully five feet, bearing flowers of various shades from scarlet and rose to lavender, which rarely if ever exceed in size a diameter of three inches. It is one of the earliest forms to 
bloom, but its tallness is a serious objection, the slender stems not being able to carry the weight of leaves and flowers, and, even with the aid of staking, the plants are nearly certain to be prostrated by wind or rain before the blooming season is over.

There is not a little merit in some of the varieties to be found in what was called a few years ago Wilks's Improved Rheas, and I got from the mixed seeds of this strain some beautiful shades.

$P$. umbrosum is simply a variety of Rheas from the Caucasus, bearing a single scarlet flower with a black blotch at the base of the petal, sometimes margined with ash gray.

For some years past I have saved annually the seeds of certain Rheas Poppies of attractive colors, and have gradually worked up a considerable number of charming varieties. There is a mottled section of great beauty that I have labored with for several years. It bears a large single flower, five and one-half inches in diameter, of a delicate rose color, mottled or veined with lavender. Other shades embrace pure lavender, scarlet, rose, and dark ruby, some plants producing very double flowers. I mark with a tag 


\section{AND THE WILDERNESS BLOSSOMED}

a Poppy that is specially interesting, and keep its seed separate in the endeavor to perpetuate the strain. At first the flowers do not always come true from seed, and show undesirable variations. Such plants I promptly root out and have gradually been able to confirm the desired coloring. This is interesting work, and I know of no flowers that offer greater possibilities for improvement than this section of the Poppy family.

P. pavonium, or Peacock Poppy, is, I think, a distinct species from Central Asia. It bears a small single scarlet flower, with a black blotch at the base of the petal, and in appearance is not unlike the umbrosum. The capsule, or seed-pod, is, however, quite distinct, being almost round instead of egg-shaped, and is covered with bristles instead of being smooth. There is nothing especially attractive about this Poppy, it being only interesting from a botanical point of view, as a distinct species.

By far the most important acquisition of late years to this family is the TULIP POPPY from Armenia, $P$. glaucum, a distinct species of great beauty. It scarcely exceeds a height of fifteen inches, and the delicate plant bears a profusion I 98 


\section{ANNUALS}

of glowing scarlet flowers. The erect form of two of the petals, almost closing together at the tips, gives the blossom a tulip-like appearance. A bed of this Poppy, covered with its brilliant flowers, looks at a distance like a glowing mass of burning coals. I know of no other shade of this Poppy, and I have never known it to cross with any variety of $P$. Rheas, though I have had beds of the two species growing within a few feet of each other for several years. The seed-pod is much smaller than that of the Corn Poppy, and is short oblong in shape, the seed itself being smaller than that of any other species within my knowledge.

None of the various species of annual Poppies can be easily transplanted, nor does there seem to be much advantage in attempting it. To secure early flowers you should plant the seeds in the fall where they are to grow. I have had some varieties of the Corn Poppy in bloom as early as June I $3^{\text {th }}$ from seeds planted in the fall, but they are at their best during the latter half of July. The Opium Poppies are somewhat later than the Corn Poppies, the double forms being the latest of all to bloom. Seeds may also be planted in early spring or even later, and from seeds 


\section{AND THE WILDERNESS BLOSSOMED}

sown about the first of July I have had a fresh bright mass of bloom in September. Like all small seeds, that of the Poppy should be simply scattered evenly upon the surface of the bed. If you are generous in your sowing the birds can get their share-and you will still have enough to crowd the bed with plants. Any excess of plants must be weeded out to secure free blooming, and it will be found even more necessary to prevent overcrowding with the Opium Poppy than with its relative the Corn Poppy.

Next after the Poppies should, in my estimation, come the Sweet Peas, Lathyrus odoratus. With this beautiful flower the preparation of the soil is a matter of prime importance. In the fall I clear off the space reserved for Sweet Peas, and spread over it roughly the dressing from the earth-closets, leaving it there on the surface for the winter. As early in the spring as the ground can be worked, I add a coating of unbleached wood ashes and bone-dust, with garden phosphate, the whole being lightened with about an inch in depth of leaf mould. The soil is then thoroughly forked up, and the seeds are planted in drills, about five inches deep, at a distance apart of two inches. Thus far the result has 
been most satisfactory, the vines having been uniformly large, sturdy, and full of bloom. Originally I built a trellis of poultry-wire netting four feet high, but it was totally inadequate for the service required, the vines growing quickly to the top and hanging down to the ground on the other side. I replaced it, therefore, with another ten feet in height, and the vines go to the top of this and still hang over. I have measured vines in the fall that exceeded twelve feet in length. It is stated that Sweet Peas do best in a position not exposed to the continuous rays of the sun, and my trellis fulfils this requirement. At the same time I have a second row of Sweet Peas planted on the terrace close to the wall, where, with its southern exposure, the vines receive the direct rays of the sun, beating all day long against the rocks, yet, during the season of 1900, which was remarkably warm and dry, the Sweet Peas were at their best in the more exposed situation, and they have uniformly done quite as well there as in the more protected position. Mr. Eckford recommends planting in clumps of two or three plants at a yard or more apart, as giving better results than planting in rows. All authorities unite in commending constant cutting 


\section{AND THE WILDERNESS BLOSSOMED}

of the flowers so that no seed can form, whereby continuous and increasing flowering will be insured. This precludes the possibility of your gathering your own seed, but this is of little moment, as perfectly satisfactory seeds can be purchased at a reasonable price, which will come true to the promised colors. The beds must be kept wet during blooming, and some mulching that is, covering the surface of the ground with various light materials, such as leaf-mould or manure, to prevent the drying of the soil - is of advantage. A thorough wetting with manure water once a month would also be advantageous, and excite renewed growth and increased bloom to the vines. If the vines grow too rapidly, giving comparatively little bloom, I clip off the tops and add wood ashes to the manure water. I have also at times added a handful of nitrate of soda to the watering-pot and thought it beneficial. The seedsmen have created something like two hundred varieties of Sweet Peas, by far the greater portion being merely a duplication of names for practically the same coloring, and twenty-five varieties would about cover all that are essentially different. As a decoration, a mass of Sweet Peas of the same coloring is far more beautiful than a 


\section{ANNUALS}

number of different colors, and therefore I prefer to plant a goodly number of seeds of a few choice varieties. I have more than once tried planting Mignonette or Shirley Poppies beside the Sweet Pea vines, and though the result as a whole was most attractive, covering up the bare ground, my experience is that the presence of any plants close to the vines retards their growth and lessens their production of flowers.

There is a dwarf Sweet Pea highly commended by the growers, called the "Cupid," which I have tried for several successive seasons, but without any good results. It is possible that others may have succeeded with this new plant, but my experience has been most discouraging. The seeds germinated and the plants bloomed, but the flowers were small and scanty.

Salpiglossis sinuata is a Chilian plant, which was fully described a century or more ago, and yet, as an ornament to our gardens, it seems to be almost unknown. It resembles the Petunia somewhat in shape, but its colorings are the richest imaginable, and in texture appears as if made of the finest and silkiest of velvet. There are numerous colorings in the species, enabling the seedsmen to offer unnumbered named varie- 


\section{AND THE WILDERNESS BLOSSOMED}

ties. I would purchase none of them, as the mixed seeds alone will furnish abundant variety, and if you do get the "New Emperor" or the "Old Guard," you will wonder when they bloom wherein they differ from, or are in any wise better than hundreds of varieties in your mixed beds. It is said to be a half-hardy annual, but be that as it may, it grows well from seed sown in the open ground in early spring, and the seed will germinate and produce earlier flowers if sown in the fall.

Whether all flower-lovers will agree with me or not, I can delay no longer in introducing our old and valued friend, the Nasturtium, of which there are three species in cultivation. Tropeolum majus, the common Nasturtium, has two varieties, - the Climbing, and the Dwarf, or Tom Thumb Nasturtium. $\mathcal{T}$. minus is the smaller Nasturtium, properly so called, for its flowers are smaller than the common. It is offered by the seedsmen under the name of Trailing NasturTIum, Tom Pouce. It is said to do better in poor soil than the majus species, but I have not tried it. We have also the well-known T. Lobbianum, a climbing species from Colombia. It is easily distinguished from all other forms by the fact that it is hairy all over, excepting only the 


\section{ANNUALS}

petals and the upper side of the leaves. I use the Tom Thumb variety for Dwarf plants and the Lobb's Nasturtiums where I desire climbing or trailing plants. My two principal Nasturtium beds have been arranged around old stumps, in which the centre has been hollowed out and filled with earth. The earth has also been dug up about two feet wide around the base of the stumps, and both in the stump itself and in the ground about, I plant the Lobb's Nasturtium. I also use the same species in open spaces in the shrubbery border and in unoccupied parts of the rose beds. I plant in the spring about six inches apart, and an inch in depth, thinning out later to a foot apart. Nasturtiums are said to do well in poor soil and in partial shade. I have found them to do best in good soil, and they absolutely refuse to develop satisfactorily if planted too thickly or are too close to other plants. A bright-colored climbing nasturtium is a most beautiful ornament amongst the rosebushes, if allowed to climb at will over the branches. It does not attain a height sufficient to interfere with the roses until their period of bloom is about over. The Lobb's Nasturtium may be planted beside a trellis or a wall, in the ledges of the rocks, or on 205 


\section{AND THE WILDERNESS BLOSSOMED}

level ground, and I think it is most effective at the head of a grassy bank or a low terrace. Both varieties bloom from July I $5^{\text {th }}$ to frost. The seeds, if picked when green, make a delightful pickle, and the blossoms are a great addition to a dish of salad both from their brilliant colors and their pungent flavor. The seeds are easily gathered and may be picked from the vines when turned brown, or gathered from the ground after they have fallen. Apparently this is the ordinary way of gathering them by the professional seedgrowers, judging from the proportion of small stones that are so often supplied in the packages. The seeds can be bought in separate colors at from fifteen to twenty-five cents per ounce. You can generally be reasonably assured of your flowers coming true to the stipulated colors, but now and then a plant will show a variation. The seeds cannot be planted in the fall in northern regions as their germinating power is destroyed by the frost. This must be taken account of in storing your seeds for the winter, and they must not be subjected to a very low temperature. It is said that the Nasturtium is easily propagated from cuttings in September, and may be kept under glass for the winter. I have not tried it, and it 206 


\section{ANNUALS}

hardly seems to me to be worth the labor, unless it be for the purpose of perpetuating with certainty some new color.

Lychnis Haggeana, or LAMP Flower, one of the best of its group, is said to be a hybrid between $L$. grandiftora and L. fulgens. It grows two feet or more high, and is covered for several weeks with flowers varying in color from a brilliant scarlet to salmon, and light pink, shading to almost white, though the darker shades predominate. The flowers are two inches or more across. The seed is easily gathered, and may be sowed late in the fall or early spring, the latter being by far the best, as, though a true perennial, the plants will bloom the first year from spring-sown seed. The Lychnis is all the better for partial shade and a cool spot, and it will bloom from the Ist of July to the $17^{\text {th }}$ of August.

The China, or India, Pinks, known as Dianthus Chinensis, D. Sinensis, or D. Heddewigii, have a long list of named varieties, either in Latin or English, of single, double, or fringed forms. They are amongst the most beautiful of summerblooming annuals, and will repay all the care bestowed upon them. They do best in dry, welldrained soils, and in such a position they are said 


\section{AND THE WILDERNESS BLOSSOMED}

to survive a moderate winter, but none have ever lived over winter on the island. I plant early in the spring where they are to bloom, and get flowers about the first of August, lasting until frost. They grow to a height of about one foot, though there is a dwarf variety which does not exceed six inches. A satisfactory bed can be secured from the mixed seeds of both single and double forms of what the dealers call $D$. Heddewigii. In named varieties I have had satisfactory results with Crown of Perfection, and Souv. DE La Malmaison, amongst the double forms, and Eastern Queen, Salmon Queen, and Glare of THE GARDEN, in the single flowers.

Callistephus hortensis, or C. Chinensis, the CHINA Aster, presents not a little variety in the forms of the blossoms, and the colors range from white, pink, rose, scarlet, carmine, lavender, and indigoblue, to purple. Some varieties are but six inches high, while others exceed two feet. Probably the finest of the taller varieties is the VICTORIA, while amongst the dwarfer forms the CHRYSANTHemum-FLowered is the best. The Quenn of THE EARlies, as its name indicates, is a specially early kind and valuable for that reason, though its range of color is but small. Other 208 


\section{ANNUALS}

varieties will appeal to special tastes. To insure success, Asters should have a deep rich soil, with an abundance of manure worked deep in the bed. In dry weather water must be freely supplied to the plants, and before the flowers begin to bloom a top dressing of well-rotted manure should be given them. To secure early bloom the seeds should be planted in a cold frame in April. I plant, however, in May in the beds where they are to grow, and weed out the larger sorts so that they stand fully a foot apart. They bloom from August I $5^{\text {th }}$ to frost, the Queen of the Earlies being about a fortnight in advance of the other varieties.

Centaurea moschata, or Amberboa moschata, $A$. odorata, or SweEt Sultan, is a beautiful flower for the garden, is fine for decorative purposes, and lasts a long time after being cut. I have worn a specimen in my buttonhole for fully two days before the flower looked wilted. It comes in three colors, white, rosy-purple, and citron-yellow, the latter being also known as $C$. suaveolens. Some improvements have been made of late in the size of the flowers, and of course new names have been invented, such as $C$. imperialis, $C$. Margarite, and $C$. chamaleon. It grows about two feet high, 


\section{AND THE WILDERNESS BLOSSOMED}

the flowers being about three or four inches in diameter. The seed should be planted in the early spring where the plants are to grow, as they cannot be successfully transplanted. They are said to do well in a sunny location, but in my experience they have done better in partial shade. The "Mammoth-flowering" varieties have blossoms quite as large as the old forms, though the price of the seeds is much larger and finer.

Reseda odorata, the Mignonetre, is grown for the delicious scent of its small inconspicuous flowers. It is a native of northern Africa, and is called hardy, though its seed will not survive the winters of Maine, but must be sown in the early spring. It grows well in either sunshine or partial shade, and prefers a light sandy soil. I always sow the seed where it is to bloom, never attempting to transplant. The seeds of many varieties are offered for sale under special names, but the best in my experience is Machet's Perfection, which is a strong vigorous plant, well branched, and bearing large heads of flowers of an intense perfume. It blooms on the island from August ist to September 2oth.

Cosmos bipinnatus comes from Mexico, growing nearly seven feet high and blooming profusely 


\section{- ANNUALS}

from early in October until cut down by frost. The flowers are attractive, and the foliage is highly ornamental. Unfortunately its late blooming renders it an impossible plant for northern Maine, but the development of an early-flowering variety has practically added a new flower to northern gardens, as it is in full bloom in early August, continuing into October. It is dwarfer than the old form, hardly exceeding four feet in height, and it bears numerous flowers in white, crimson, and pink. The seed, which is scarcely more than half the size of the old form, should be planted in early spring in the place where the plants are to grow. It does well in the sun, and likes a rich moist soil, but, owing to its height, it should, if possible, be planted where it will be in some measure protected from heavy winds.

The genus Coreopsis, besides the perennial species already referred to, furnishes several choice annuals. It is curious to note that the seedsmen almost invariably use the name Calliopsis for the genus when referring to the annual species, and yet place the perennials under the proper name, Coreopsis. The annual species generally cultivated are as follows : C. tinctoria, in which the lower half, or sometimes almost the whole of the 


\section{AND THE WILDERNESS BLOSSOMED}

rays, are crimson brown, the tips being orange yellow. When the whole of the flower is crimson brown, it is called $C$. atrosanguinea, $C$. atropurpurea, or C. nigra speciosa. C. Drummondii, or Golden WAVE, has golden yellow flowers with a small dark spot at the base of the petal. C. coronata has a yellow flower with a darker purplish-streaked spot near the base. On the island these flowers uniformly reach a height of four feet, and are profuse bloomers. I prefer the darker varieties of $C$. tinctoria, and always gather my own seeds, planting late in the fall. The seeds are small and need only be scattered broadcast on the bed. The Coreopsis likes good rich soil and plenty of sunshine, blooming from July 18 th to frost.

Gray classes the Mayweed under the genus Anthemis, but others group the seventy-odd species in the genus Matricaria. All the species are natives of Europe, Africa, and western Asia, and all are weeds with the exception only of Matricaria inodora plenissima, or Anthemis chamomilla flor pleno, as other botanists call it. The seedsmen, possibly from a desire to save this flower from the humiliation of acknowledging its host of poor relations, have in the kindness of their hearts followed the lead of 


\section{ANNUALS}

Linnæus and christened it with the more aristocratic name of Chrysanthemum inodorum plenissimum, which certainly ought to satisfy any flower, however ambitious he may be. I remember on one occasion, when driving through the hills of Maine, I saw a little goldfinch with his golden-yellow and black plumage flying in and out amongst the bushes by the roadside.

"What do you call that bird?" I asked of the native driver.

Looking at it critically for a moment, he replied serenely, "We call that a little red-bird."

Once a farmer landed his boat at the island wharf and carefully deposited a covered pail on the platform. I greeted him with a "Goodevening, Haines; what have you got there ?"

"Plums," was the laconic answer.

"Plums!" I said in surprise, adding, " I 'm glad of that," as I tore off the covering, when I exclaimed with still greater surprise, "Why, these are strawberries!"

"Yes," said Haines, complacently, "we call 'em plums."

There is a dwarf tree in northern Maine which bears in the fall a minute red plum, and the natives all call it a "sugar pear." Now, if any one 


\section{AND THE WILDERNESS BLOSSOMED}

can tell me why these good people call a yellow bird red, a plum a pear, and a strawberry a plum, we may possibly be able to guess why the seedsmen call a species of Mayweed a Chrysanthemum.

Notwithstanding its humble origin, Matricaria inodora flor pleno or plenissima, as I think it ought to be called, is a very desirable plant for the border. It is perfectly hardy, has attractive, feathery foliage, blooms the first year from seed, and reproduces itself bountifully by self-sowing. It excels any flower $I$ know of in its free blooming qualities. If given good soil, not too rich, and plenty of room, it will form into a compact recumbent plant, three feet in diameter and fifteen inches high. One such plant that I grew from seed had, by actual count, over five hundred flowers in bloom upon it at one time. The flower is white, about two inches in diameter, and at its best is intensely double. The plant shows a strong tendency to go back to single or semidouble forms, and if you would retain the best variety you should root out the undesirable plants and permit only the choicer double forms to cast their seeds. The best of the blossoms should be marked, and seeds collected from 



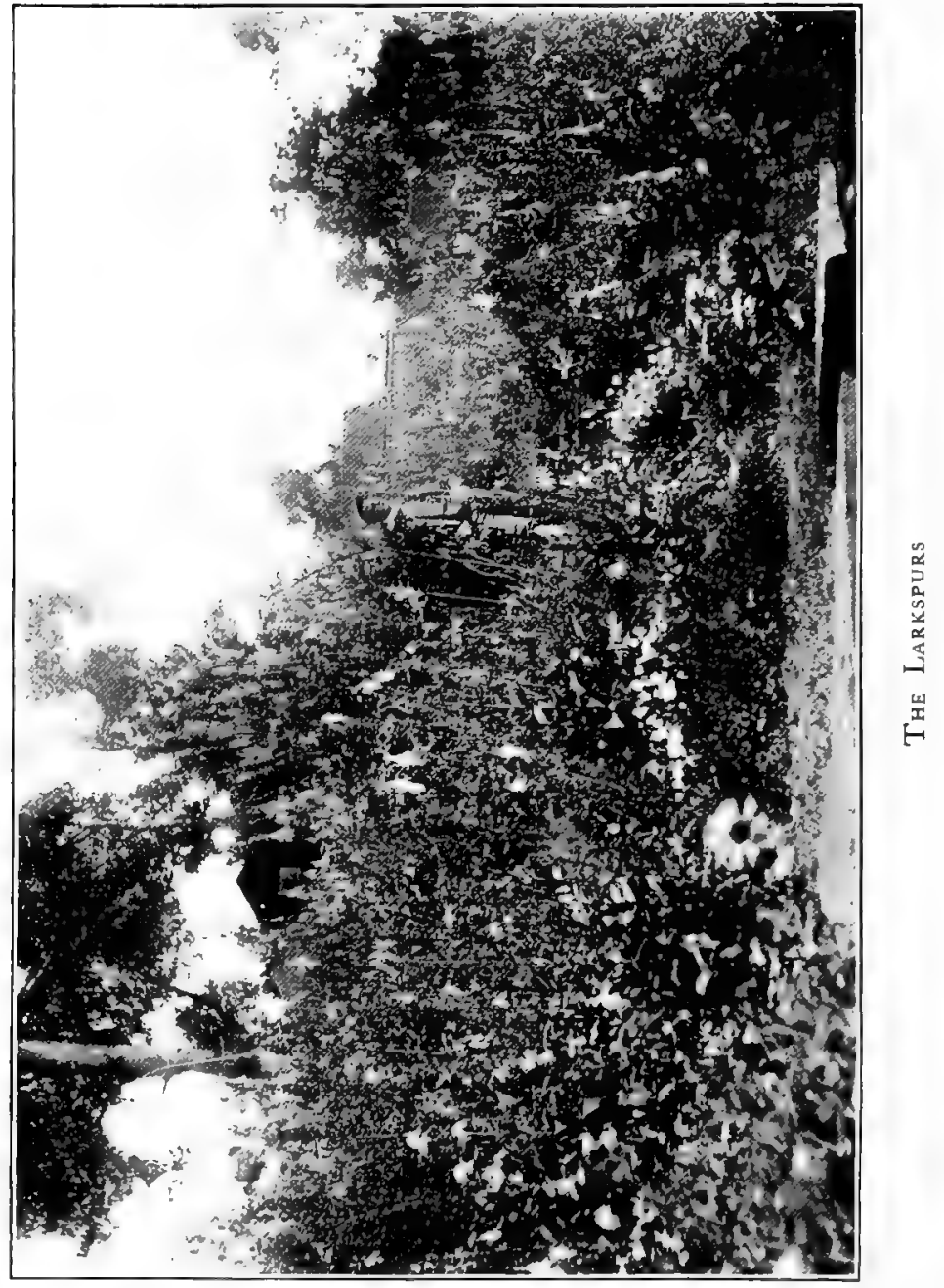




\section{ANNUALS}

them alone. You will not find it troublesome to gather all the seeds you will need. I always sow the seed in the fall, and thereby get flowers by the first week in July, in the following summer, which last until frost.

There are two species of annual LARKSPURs, -Delphinium Ajacis, the Rocket LaRksPur, and $D$. consolida, the Branching Larkspur. The former embraces three varieties commonly grown in gardens, of which $D$. majus, the TALL Rocket LARKSPUR, grows to a height of fully five feet, the flowers being double, on a long spike. The colors include white, flesh-colored, rose, violet, and ruby. $D$. minus is the Dwarf Rocket LARKSPUR, which grows about two feet high, and in addition to the colors of the taller variety, we have pale blues, and some striped specimens. The Stock-flowered is also a desirable variety of RockET, said to be worth cultivating, but I have not tried it. In BRANCHING LARKSPURs we have Candelabrum, and Imperialis, or the EMPERor, in various colors, from white to dark blue and red, some varieties being variegated. None of the Branching Larkspurs exceed three feet in height, and generally range from one and a half to two feet. The seeds 


\section{AND THE WILDERNESS BLOSSOMED}

are easily collected, and should be sown in the fall to insure early blooming. I sow broadcast on a finely raked bed, and after sowing, work the back of the rake lightly over the soil so as to settle the seeds a little below the surface. I do not sow the different colors in separate beds, but prefer to let the mass show all its variety of shade, and indeed, if a Shirley Poppy strays into the bed, as is apt to be the case, for the Shirlies live just next door, I never disturb it, but let its little pink and white face peep out from between a pair of the long legs of the bluecapped Larkspurs. It blooms from July 5 th to August 12th from fall-sown seeds.

The annual PhLox of our gardens comes from Phlox Drummondii, which was first found in Texas. By cultivation, the coloring and even the shape of the flower has been varied to a remarkable degree. There are several colorings in a double form which I do not care to raise; the single flowers being to my mind much handsomer, as they are at the same time much larger. Where a flower shows but a single shade, it may possibly be improved by doubling, but where, as is so often the case with most of the Poppies and so many others of our annuals, the beauty of the blossom 


\section{ANNUALS}

is due largely to the delicate shading of many colors in the broad, flat petals, to double it is to deprive it of the most of its charm, as you end by concealing all of the various shadings, save only that of the outer edge of the petals. These flowers may be planted in the shrubbery border, but I always devote at least two large beds to their service, preferring to see this beautiful flower in masses, showing at once all its marvellous variations of color and form. I plant the seed in the spring where it is to bloom, as early as the soil is dry enough to be worked. I give the Phlox a sunny exposure and a rich moist soil, topped off with leaf-mould after the plants are up above the ground. It blooms on the island from August Ioth until cut down by frost.

Centaurea cyanus, the Cornflower, Bluebottle, Bluet, Kaiser-Blumen, Corn-Bottle, Ragged Sallor, or Bachelor's Button, was the favorite flower of the late Emperor William, as it has been, and is now, the favorite of many thousands of less-known people. I wish to note that the name BACHelor's ButTon is applied to several other species of flowers; and among them may be named Gomphrena globosa, or GLOBE Amaranth ; Ranunculus acris, and Polygala lutea, 


\section{AND THE WILDERNESS BLOSSOMED}

the latter having the word "yellow" prefixed to the name. But the name applies to still another species, it appears, not so far noticed in any of the books. Two charming young ladies of my acquaintance were on one occasion going to a college base-ball game, and at the last moment found that no provision had been made for flowers to show their loyalty to old Yale. A corsage of dark-blue flowers they must have, and ringing for a messenger-boy, they instructed him to purchase for them two dollars' worth of "Bachelor's Buttons." The boy was gone an unconscionable long time, and the young ladies were almost in despair, when at the last moment he appeared bearing the longed-for package. It looked odd in shape and size, however, and they opened it with some misgiving. Their amazement may be imagined when they found therein only a number of small boxes containing those patent buttons which may be fastened upon shoes or trousers without the aid of needle or thread.

Originally, bearing a single dark blue flower, many other colors of the Cornflower have been produced by selection, and we can now obtain white, rose, light blue, and dark purple, with varieties striped and mottled, and also double 


\section{ANNUALS}

forms of some of these colors. Though many of these new shades are attractive, I confess to a prejudice in favor of the old-fashioned dark blue. The Cornflower is easy of cultivation, and will do well in almost any situation, but it requires room above all things else, and the plants cannot do their best if crowded for space. The seeds are a little tedious to gather as well as to clean, much of the chaff being of the same size as the seed. The pods should be picked just as they are ready to open out, and you will find the largest number in this condition after a day or two of cloudy weather, as the pods do not expand and drop their seed excepting under the influence of a hot sun. If you desire to keep colors separate, you should mark your plants, but this will not be necessary if you begin gathering early, as the flowering period is long, extending on the island from July $14^{\text {th }}$ till frost, and you will be able to get plenty of seeds for your beds while the plants are still blooming. I invariably plant my seeds in the fall, thereby getting much stronger plants and several weeks of extra bloom. The plant casts its own seeds, and it will fill with its plants all vacant places in its neighborhood. It may be transplanted, but this weakens the 


\section{AND THE WILDERNESS BLOSSOMED}

plant and delays its blooming, and so I scatter the seed in the fall wherever I think I may possibly want a plant, and if I change my mind in the spring, it is easy to pull out what I do not want.

Calendula officinalis, or Pot Marigold, is in many ways a most desirable plant. It is easy of cultivation, perfectly hardy, a free bloomer, and flowers on the island from July $25^{\text {th }}$ to frost. Its blossoms are large, showy, and not ungraceful. It grows to a height of eighteen inches, and does well in many situations, though it seems to require a good soil, plenty of room, and a warm sunny position to produce the best results. There are a number of varieties, all of them attractive. Lemon yellow, golden yellow with maroon centre, yellow striped with orange, orange, and sulphur yellow striped with white, are the usual shades. The seed is easy to gather, and large quantities may be obtained with little trouble. With this flower, as with so many others, it is wise to mark choice blossoms, and to use the seed from them alone. One instructor advises us to "sow in boxes early, or in open ground in May or June; transplant to one foot apart," I advise you not to sow in boxes, nor 


\section{ANNUALS}

ever in May or June, and under no circumstances to transplant. Seeds sown in the fall will germinate freely in spring, and produce earlier flowers and sturdier plants than you can get in any other way. In planting, scatter your seed broadcast evenly over the bed, and then work the soil lightly over them with the back of the rake. If some of the seeds are obstinate, and refuse to be covered in this way, you may press them under the surface with the finger-tip. The seeds will do better, if after all this you press the soil down lightly with the palm of the hand or a suitable board.

The genus Tagetes furnishes three species of Marigolds, 一 $\mathcal{T}^{\prime}$. erecta, the African; $\mathcal{T}^{*}$.patula, the French; and $\mathcal{T}$. signata, the DWARF MARIGOLD. All are natives of Mexico and South America. The African Marigold is the tallest of the genus, growing to a height of fully thirty inches, and bearing the largest flowers, some double varieties showing blossoms over four inches in diameter. The range of color is not extensive, embracing only a deep orange and a pale yellow. The flowers are both single and double; but seed from the latter, though carefully selected, is apt to produce a considerable 


\section{AND THE WILDERNESS BLOSSOMED}

proportion of single flowers. One of the best of the large flowering class is known as PRIDE of the Garden, or Delight of the Garden, as the dealer prefers.

The French Marigold is somewhat dwarfer, rarely exceeding eighteen inches in height, its flowers displaying yellow, orange, and brownish shades, striped and mottled. A dwarf form of the French Marigold, $T$. patula nana, is a compact plant from six to twelve inches high, very free flowering, with a dark brown maroon or yellow blossom, single or double. The seed of this variety is sometimes offered under the name of Little Brownie, or Legion of Honor, Lilliput, or Toм Thumb.

$\tau$. signata resembles the French Marigold in some respects, but has smaller yellow-striped flowers and grows about fifteen inches high. A dwarfer form is $\mathcal{T}$. signata pumila.

I sow the seeds of all species of Marigolds in the open ground in spring, after the danger of frost is over, and in the bed where they are to bloom. The seed will not survive the cold of winter, and therefore cannot be planted in the fall. The plants are in full bloom by the first of September, continuing until cut down by frost. 


\section{ANNUALS}

If earlier bloom is desired, the plants must be started indoors. Both the African and French Marigolds do well in rich loam, but signata requires poor soil to produce the best effects in bloom. Owing to the late period of flowering, I have never been able to gather the seeds of the Marigold. However, I have had no difficulty in getting satisfactory results from seeds purchased from the dealers, with one exception, when no seeds at all out of full two ounces seemed to possess the power of germinating.

It is a pity that the CALIfornia Poppy was not discovered by a botanist bearing a more manageable name than Eschscholtz, and it was a poet too, Adalbert von Chamisso, who was guilty of the atrocity of naming the genus Eschscholtzia in honor of its discoverer. Notwithstanding its abominable name, it is a beautiful and desirable flower, a perennial in its native home, southern California, but in the north treated as an annual. It grows about fifteen inches high, and the type, E. Californica, bears a bright orangeyellow flower, darker at the centre and lighter at the extremities. There are a number of varieties, much confused, because much mixed in growing together. $E$. crocea is of a deep yellow or saffron 


\section{AND THE WILDERNESS BLOSSOMED}

shade; $E$. crocea alba is white; $E$. crocea mandarin has the inner side of the petals rich orange and the outer portion bright scarlet; $E$. crocea rosea, intense carmine ; and $E$. crocea flor plena is semidouble. E. Douglasii or E. maritima is a variety bearing somewhat larger, pure yellow flowers, and $E$. aurantiaca, rich orange. The Golden West Eschscholtzia, as described by seedsmen, offered nothing new in the way of color, but it was stated that "the flowers of these new giants measure from four to six inches in diameter." The italics are not mine, but neither were the giants. I paid a large price for a very small package of seed, and had the pleasure of seeing the plants produce just the same-sized blossoms I had obtained from mixed seeds at twenty cents an ounce. From the Bush Eschscholtzia I got even less, for not a seed germinated. Except when dealing with choice novelties, such as these, the California Poppy is a very easy flower to raise. The seeds should be sown broadcast on the bed where they are to bloom, and then gently settled into the earth. I plant my seed invariably in the fall, sometimes as early as the first of September, though they appear to do as well if planted the latter part of the month. 


\section{ANNUALS}

Sow the seed generously, and if the plants crowd each other the following spring, weed them out. Never attempt to transplant. The Eschscholtzia does well in the sun and in a rich soil. Its bloom is at the best from June 2oth to August Ist, but it continues to flower sparingly till frost.

Alyssum maritimum, the well-known SweEt Alyssum, grows about nine inches high, and is covered from June 2oth until frost with a luxuriant mass of small white flowers. There are some dwarf varieties, - $A$. Benthami compactum, or Tом Тнuмв; $A$. compactum erectum, or Lițte GEM, growing about six inches high; and $A$. compactum procumbens, or CARPET of Snow, which scarcely exceeds three inches. Much praise is devoted to the Littre Gem variety by the seedsmen, but with little justification, to my mind, the type being far superior to any of the varieties. Simply because a flower differs from the type is no reason for preferring it, and I feel quite sure that if the Little $\mathrm{G}_{\text {zm }}$ were the type and $A$. maritimum the variation, the growers would become most enthusiastic over this wonderful improvement in a common flower. The cultivation of Sweet Alyssum is of the simplest. It should be sown 


\section{AND THE WILDERNESS BLOSSOMED}

in the fall where it is to grow, and after that it may be left practically alone and be permitted to look after itself, as it will seed itself annually for several years, and thrive, if the bed is kept free from weeds and given a dressing of manure in winter. Indeed, after it is once established in a bed, it persists in remaining there, although you may dig the soil up annually and plant other species therein. It looks well amongst the shrubbery, quickly covers bare spots on the border, and is altogether a most desirable little plant, being far superior to any of its perennial brethren. A light sandy soil is best suited to it, although it will grow well in almost any soil or in any situation.

There are two species of annual CAndytuft commonly grown in gardens, Iberis umbellata and I. amara var. coronaria. I. umbellata, the common CAndytufT, bears its flowers in flat clusters. It varies in height from eight inches to twelve, producing flowers of several shades, including white, rose, crimson, carmine, lilac, purple, and rose-cardinal. I. amara var. coronaria, or Rocket CANDytuFT, bears only white flowers in dense spike-like racemes. The taller sorts grow to a height of twelve or fifteen inches, and the seeds- 


\section{ANNUALS}

men's catalogues include such names as White Rocket, Giant White, Giant Snowflake, Empress, Snow QueEn, and Hyacinth-Flowered, all being probably only different names for what is practically the same flower. Dwarf varieties are Tom Thumb and the Litrle Prince, growing from four to six inches high. I do not care for I. umbellata, and of the Rocket varieties I much prefer the large Giant-Flowered or EMPRESS strain. It blooms from June 2oth to frost, and its cultivation is the same as Sweet Alyssum, though the results are not always as satisfactory, the seed apparently not germinating as freely nor as certainly.

Zinnia elegans, coming originally from Mexico, is a striking flower when grown in masses on the lawn. It comes double and single, but in the anxiety to produce striking double forms, the single blossoms have been almost lost sight of by the seedsmen. This is a pity, as when in a mixed lot of seed you sometimes get a large single flower of yellow, orange, scarlet, or crimson, it is often more attractive than the double forms, though few of the dealers offer the seeds of single varieties. The colors of the double forms embrace white, sulphur-yellow, canary- 


\section{AND THE WILDERNESS BLOSSOMED}

yellow, orange, flesh, rose, carmine, scarlet, crimson, violet, lilac, and purple, and there is also a

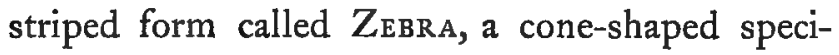
men known as the Pompon, and a Curled and Crested variety. In my experience but a small percentage of the colors come true from seed, and $I$ find it quite as well to purchase the mixed seeds instead of the separate colors. A large flowering strain called Robusta plenissima, or GIANT Маммотн, grows about three feet high, and is said to bear flowers five or six inches in diameter. It is an excellent variety, and I have grown it for several years, but I never yet saw a flower that approached the advertised size, although the soil and location were the best possible for growing Zinnias. There are some dwarf varieties also, among them being Double Liliput, Fairy Gem, and Miniature. The latter grows but four inches high, and is only a curiosity, the flowers being small. There are some attractive features about the other dwarf forms, as they are hardly as rank in growth as the type, and the flowers are fuller and richer. The Zinnia is a tender annual, and the seeds cannot be sown in the fall. It is the usual practice, I think, to sow them in boxes in March or April, and not to set 


\section{ANNUALS}

the plants out till June. Indeed, one authority recommends that transplanting to the open beds be delayed until the plants begin to bloom, when you can select the finest colors. I would not dream of following this advice, as I know of no flowers that are not injured more or less by attempting to transplant after the bloom has started. I sow my seed in the open ground, in shallow drills, the last week in May, and then weed out the young plants until they stand twelve inches or more apart. The bed should be rich, with plenty of bottom dressing, the soil fine, and situated in the brightest, sunniest corner of the garden. The plants should be watered freely in dry weather. The Zinnia blooms from July I 8 th to frost on the island.

There are several well-defined species of annual Sunflowers, but Helianthus annuus, and $H$. argophyllus are said to be the parents of most of our garden varieties. The latter species comes from Texas, and is distinguished by its hoary-white foliage. $H$. debilis, uniformly called by the seedsmen cucumerifolius, is a dwarf variety not exceeding three feet in height, which bears numerous yellow flowers with a black disk, three inches in diameter. If given plenty of room, 


\section{AND THE WILDERNESS BLOSSOMED}

the plant becomes much branched, and is quite symmetrical. Stella, a variety of the last, is easily to be distinguished from it by the higher price of the seeds. $H$. variegatus grows about six feet high, bears a single yellow flower, and has its leaves striped and blotched with yellow. H. Californicus grows six feet high, and is one of the best of the double sunflowers, the petals being of a rich orange shade. $H$. globosus fistulosus is also six feet high, with double saffron flowers. $H$. Peruvianus has double orange flowers, striped black. H. nanus flor pleno, or Globe of Gold, is a dwarf plant four feet high, with very double flowers of golden yellow. $H$. sulphurus, or Sulphur Gem, is a well-branched plant, bearing single sulphur-yellow flowers with a black centre. It continues in bloom until frost and is a desirable variety. H. multiflorus, or ТночSAND-FLOWERED, is a tall variety which bears numbers of golden-yellow flowers with small black centres. H. macrophyllus giganteus is a branching pyramidal-shaped plant, six feet high with yellow flowers. The Giant, or Mammoth Russian, bears immense single heads of flowers, and is said to be cultivated frequently for its seeds, which are used as chicken feed, but my 


\section{ANNUALS}

chickens never would have anything to do with them. As an ornament on the lawn, and certainly for decorative purposes, I prefer the dwarf $H$. cucumerifolius to any other variety. All varieties do best in a rich soil, and require plenty of moisture. The seeds are easy to gather and may be planted in either fall or spring, the fallsown plants flowering about July $15^{\text {th }}$, while those from spring planting do not bloom before August Ist on the island.

Layia elegans is a hardy annual from California. It is a dwarf plant, scarcely exceeding ten inches in height, and bears profusely, all summer, very attractive single flowers, about an inch and a half in diameter, the lower half being a canary yellow, and the edges margined with white. It is attractive from the prodigality of its bloom, and is easily cultivated, as it grows well in any ordinary garden soil. The seed may be sown in the fall or spring, but I always sow in September, thereby getting bloom from July i 2 th to frost. There are probably a dozen species or varieties of Layia, but elegans is said to be the best.

Nicotiana alata, or $N$. affinis, is a half-hardy annual which grows to a height of three or four 


\section{AND THE WILDERNESS BLOSSOMED}

feet, and bears from August ist to frost a constant succession of white flowers, nearly five inches long, which appear at dusk, and are then very fragrant. There is said to be a still taller variety called GIANT RED, which grows to a height of five feet and bears from July until frost immense clusters of rich crimson flowers. I am not yet able to confirm this statement, for although I have bought the seeds annually for several years, and planted them with the utmost care, I have yet to see a single crimson flower. $N$. alata does best in rich soil and in a somewhat sheltered position. Some twenty-five feet westward of the bed I use for them is a fringe of tall trees which shelters them from the afternoon's sun, and induces the blossoms to expand earlier in the day than common. They look well growing with other plants, and I sometimes lay a carpet of Sweet Alyssum at their feet which does not appear to interfere with their growth or blooming. Some authorities recommend sowing the seed as early as February in a warm house, and transplanting to the open ground the last of May. I have had very satisfactory results, however, by sowing my seed broadcast in September where the plants are to grow, and have had stout 


\section{ANNUALS}

hardy plants as a result, which bloomed earlier than those from spring-planted seed. If the plants are left alone they will seed themselves almost as freely as Sweet Alyssum.

The Cruciferea, or Mustard Family, which includes Alyssum, Candytuft, Wallflower, and Rocket, has also given us the Stocks, Matthiola. There are two species, $M$. incana, the common Sтоск, a perennial or biennial, which is the source of the Brompton and QueEn Stock, and $M$. annua from which the TEN WeEks and Intermediate Stocks have been derived. Some authorities make a third species $M$. sinuata, and refer to it the Intermediate section. Doubtless in a milder climate the Ten Weeks Stock would be placed far higher on such a list as this, but as I am 'making my record from personal experience alone, and can report only a moderate success with this flower, I could not give it a higher place than I have. The Ten Weeks Stock we are told has been vastly improved from the old Gilliflower type, and is a halfhardy annual, bearing double or single fragrant flowers. The varieties may be divided into tall, dwarf, and pyramidal. The tall varieties grow to a height of two and a half feet, while the 


\section{AND THE WILDERNESS BLOSSOMED}

dwarfer, larger flowering plants are about one foot high. The dwarfer varieties are the favorites generally among growers, the range of color being large, and embracing white, canary-yellow, pink, rose, scarlet, crimson, blood-red, copper, light blue, violet, lavender, and purple. There are indeed few flowers in cultivation offering a wider range of color. A still dwarfer strain is the SNowflake, a double white flower, on which the Dwarf White Pyramid is said to be an improvement. The miniature PEARL is also white and does not exceed six inches in height. The Pyramidal form is probably the best of them all, and is certainly so in my experience. The plants are neat and compact in habit, while the flowers are large, furnishing all the wellknown colors of the species. The seed is usually planted indoors in April, and the plants set out in the garden after danger from frost is past. I have uniformly planted in the open ground in May, and therefore do not get as early flowers as I might by the former method. The Intermediate species are too late in their blooming period to be grown successfully in northern Maine, and the biennials are not hardy enough to stand the cold of our winters. 


\section{ANNUALS}

Still another member of the Mustard Family claims our attention, Cheiranthus cheiri, or the WaLlflower. It is a perennial, and is not hardy enough to stand our winters, but a variety has been lately introduced which blooms the first year from seed. It bears single, cinnamon-colored flowers during August and September, from spring-sown seed, and is a desirable acquisition.

I feel quite sure that Portulaca grandiflora, the Rose Moss, ought to be much higher up the list than this, and it would be if I consulted only my personal preferences. To me this hardy, freeblooming little plant is a delight. It is a native of South America, and grows about six inches high, densely covering a space of ground fully eighteen inches in diameter. Its flowers are either double or single, the former being possibly the handsomer if you consider only the individual blossoms, but the single form makes up for this by giving us two or three flowers for every one of the double. Its range of color is large, and we have, in both single and double forms, a profusion of white, straw, sulphur-yellow, yellowstriped crimson, orange, salmon, rose, rose with carmine stripes, scarlet, and purple flowers. It thrives in a rich, light, sandy soil, when it gets 


\section{AND THE WILDERNESS BLOSSOMED}

plenty of sunshine, and a summer drought, however prolonged, never affects the brightness of its foliage nor the brilliancy of its bloom. The seed may be sown in either spring or fall, but I never had Portulaca in perfection until I let it alone and permitted it to seed itself. Since then I have always planted the seed in the fall, with results uniformly satisfactory. It is easily transplanted, and may be reproduced from cuttings which quickly take root. It seems to me that Portulaca is not at its best when planted alone. I had a bed of Sweet Alyssum and Portulaca growing together that delighted me every time I looked at it. At a distance one saw only the massed white of the Alyssum, but closer by one could peer into the bank of snow, and discern the brilliant colors of the Portulaca beneath. This makes a good combination, as both plants seed themselves. I have it also growing on a sunny bank amidst the Aquilegas. As the Columbines begin to lose their bloom, the Portulaca blossoms out and keeps the bank brilliant for the rest of the season. It is a great labor-saver, too, for once Portulaca establishes itself on a spot, few of our ordinary weeds have any chance in competition with it for space. In buying the 
seeds you will have to pay eight or ten times as much for seeds of double flowers as you will be asked for single varieties. Only a portion of the flowers, however, will be double, even if you do buy the double seeds, while if you get single seeds, you will have some double flowers, if you enrich the soil about the plants when they are couple of inches high. If you wish to have a bed all single or all double, you can gradually secure this by transplanting and setting out cuttings in place of the plants taken away. I never buy the seeds of separate colors, for they are not only very expensive, but, to my taste, useless, as the bed is much finer containing all the varieties, and in any event only a small percentage of the seeds will ever come true to color.

Linum grandiflorum, L. coccineum, L. rubrum, ReD or Scarlet Flax, is a half-hardy perennial from north Africa, which blooms the first year from seed, and therefore may be treated as an annual. It grows one foot high, and bears bright crimson-red flowers, one inch in diameter. Its foliage is fine, and the delicate stems bearing the bright flowers make it an attractive object in the bed. It likes plenty of sunshine, and blooms from July i 8 th to frost, and earlier flowers may be obtained by sowing the seed in the fall. 


\section{AND THE WILDERNESS BLOSSOMED}

Bracyhcome iberidifolia, or Swan River DaIsy, is a rather attractive half-hardy annual from Australia, of easy cultivation. It grows eight or nine inches high, bearing light blue flowers, with a paler centre, about one inch across. In shape the flower is not unlike the Cineraria, and in cultivation produces other shades of blue as well as a variety in pure white. I have always planted. the seeds in early spring, though I still hope to get a strain that may be planted in the fall and survive the winter.

I cannot understand the almost entire neglect of Asperula orientalis, or A. azurea setosa, as it has many points of excellence to commend it to the flower lover; yet few seedsmen notice it at all, and those who do dismiss it with a line. It grows twelve or fifteen inches high, has long, slender stems, surmounted with clusters of small blue flowers, which are delicately scented. It is perfectly hardy, and blooms all summer from spring-sown seed. You can, however, get sturdier plants and earlier bloom, by sowing the seed in the fall. The seeds are not troublesome to gather, and if you do not disturb the plants they will sow their own seeds.

Ipomea purpurea, Convolvulus majus, C. pur238 


\section{ANNUALS}

pureus, or Pharbitis hispida, the common, wellknown Morning Glory, though a half-hardy annual from tropical America, will succeed in the open ground in northern Maine, but it is not apparently well suited to this region, as it never grows there with the luxuriance commonly seen in more southern localities. I have always planted my seeds in the open ground in May, and doubtless would succeed better if the plants were started under cover a month or so earlier, but I hardly care to do it. The seeds will germinate earlier if soaked in warm water for a couple of hours before planting. I have tried persistently the widely advertised IMPERIAL JAPanese Morning Glories, giving them the best possible position and soil, and carefully tending them. The flowers were of charming colorings, but I got no blossoms that would measure more than two inches across, instead of the four or five inches promised by the seedsmen. There is also a dwarf form, not a climber at all, which I have tried and care nothing for.

Chrysanthemum coronarium, or Anthemis coronaria, the Summer Chrysanthemum, or Crown DAIsy, is a hardy annual growing a foot or more high. It is a native of southern Europe and 


\section{AND THE WILDERNESS BLOSSOMED}

northern Africa, and in its wild form it bears a single pale yellow or buff flower. In cultivation it also produces a white form. Its seeds should be planted in the fall, or if left alone it will seed itself.

C. carinatum, or Tricolor Chrysanthemum, is a native of northern Africa, bearing double white or yellow flowers. The variety Burridgeanum has showy rose-colored flowers with white edges. Another variety, Dunnetti, has double flowers in white, orange, yellow, or purple. This latter strain is quite attractive. $C$. carinatum is a tender perennial, but may be treated as a half-hardy annual, sowing the seed in the early spring.

C. segetum, or CORN MARIgold, is also a perennial that may be treated as a half-hardy annual. It bears a yellow flower, and the seeds may be sown in the fall. All these three species of Chrysanthemums thrive best in a rich soil and in a sunny position.

Rudbeckia bicolor, the half-hardy annual ConeFLOWER, grows about two feet high, is branching in its habit, and bears bright attractive flowers on its long stems, the disc being blackish purple and the rays bright yellow with a brownish spot 


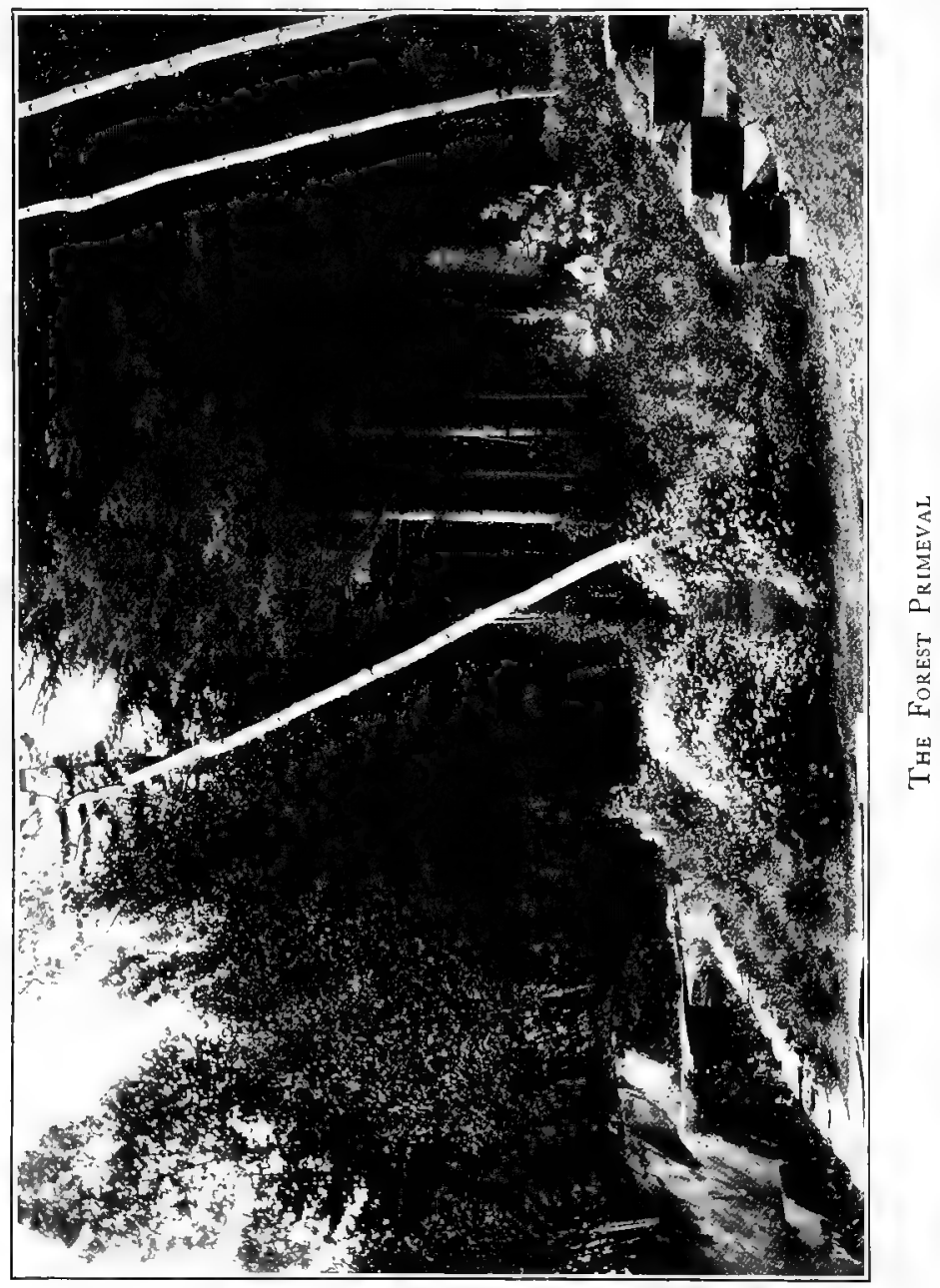





\section{ANNUALS}

at the base. It grows freely in any soil, beginning to bloom in July and continuing until cut down by frost.

Gaillardia pulchella, or G.picta, is an annual from the southwestern portion of the United States. It is easy to grow from seed, but the flower so closely resembles the perennial $G$. grandifora, and is so inferior, that, having the latter, it is hardly worth while to spend time or attention on the other. G. picta Lorenziana, on the other hand, is a double-flowering variety quite different in its appearance, but I confess its attractions were not sufficient to induce me to continue its cultivation.

Scabiosa atropurpurea, or SweEt Scabious, is a hardy annual which, when its flowers are dark purple or crimson, is called Mourning Bride. Its colors vary from white through rose, scarlet, crimson, and lilac to a deep dark purple. It is either tall, about two and a half feet high, or dwarf, from one to one and a half feet, and the flowers are either single or double. In the rage for doubling, single forms of this flower like the Zinnia have almost disappeared from the seedsman's collection, though, to my taste, the single flower is much more desirable than the stiff unI6 


\section{AND THE WILDERNESS BLOSSOMED}

gainly double ones. I have always planted my seeds in the open ground in early spring with good results, and have not yet succeeded in getting the seeds to live over the winter from fall planting.

Mirabilis Jalapa, Four-o'clock, or MARvel of PERU, is a perennial plant in a warm climate, but in northern regions it is treated as a halfhardy annual. It grows to a height of about three feet, bearing red, rose, crimson, white, lilac, purple, or variegated flowers, about one inch in diameter. It does best in the warm sunshine, and it can be propagated either by saving the roots in sand over the winter or more easily from seeds. The seeds are large, and can be gathered just as they are ready to drop, or from the ground beneath.

The genus Amaranthus gives us some plants which are useful under certain circumstances. $A$. Henderi is a foliage plant growing two feet high, with drooping leaves of rosy carmine, orange, buff, golden yellow, and olive green. If planted in rich ground in bright sunshine and given plenty of room, it has a striking effect. $A$. $t$ ricolor, or Joseph's CoAT, is a similar plant three feet high with leaves of red, yellow, and green. 


\section{ANNUALS}

A. caudatus, or Love-Lies-Blending, has long, dark red, drooping flower spikes, and is not an attractive plant to me. The best of the family are coarse undesirable plants, except in certain situations. All are easily raised from seeds sown either in spring or fall.

Gypsophilla elegans, a variety of which is called Covent Garden, is an annual having some of the virtues of its perennial relative, G. paniculata. If you have the latter well established, it is not worth while to plant the annual species, which, however, is easily grown from seed, and prefers a dry, sunny situation.

Abronia umbellata is a tender trailing perennial from California, with rosy purple, fragrant flowers in clusters. It is rather attractive, easy to grow, and thrives in a dry soil, or in the crevices of the rocks in a sunny situation. It may be treated as a hardy annual, and will seed itself, or the seeds may be sown in the fall.

Godetia grandiflora, or G. Whitneyi, is a western American flower of some interest. It grows from one to two feet high, bearing numerous flowers, two inches or more in diameter, in shades of pink, rose, blood red, or white mottled and striped with red. The double-flowered rose 


\section{AND THE WILDERNESS BLOSSOMED}

variety is attractive. It is easily raised from spring-sown seed.

Rhodanthe maculata, or Everlasting, is a halfhardy annual from Australia, about one foot high, bearing white, pink, or crimson flowers, which are especially remarkable for the length of time the bloom lasts after being cut. They retain their color and shape if dried and hence are ranged with the Everlastings. They are easily raised from seed sown in the spring, and bloom early and continuously until frost.

Schizanthus pinnatus is nearly related to Salpiglossis, and is an attractive flower, being like its relative also from Chili. It grows about one and a half feet high, bearing rosy purple or yellow blossoms, freely mottled, and about one inch in diameter. The seeds may be sown in either spring or fall, but the latter time is much the best. It thrives in a rich, light, sandy soil.

Clarkia elegans is a hardy annual from California, of which I know only enough to say that it is attractive, and suited to our climate. It does well in the sun and also in partial shade. The plant is two feet high, well branched, with long racemes of double purple, rose, or salmon flowers. The seeds should be sown in the fall where the 


\section{ANNUALS}

plants are to bloom, and in rather moist soil, not too rich or fine.

I have raised Cleome grandis, Hibiscus Africanus, and Specularia Speculum, or Venus' LookingGLASS, and having done so once am not tempted to do so again. 


\title{
CHAPTER VIII
}

\author{
SEEDS
}

"Here's a state of things! Here's a pretty state of things!"

U

NDER each species of flowers described, I have said something about the planting and gathering of the seeds, but I wish to say here some further words upon the general subject.

In nature a flower when its seeds are ripened drops them upon the soil, where they germinate at the opening of another season, and from them plants spring up which in turn bloom and again produce seed. Under ordinary circumstances, then, the proper time to plant all seed would be in the fall, as nature plants them; and this rule would be invariable if all the flowers we attempted to grow were natives of the same sort of climate that we have in our own gardens. But the botanist has brought flowers to us from all over the world, and we are attempting to grow plants 246 


\section{SEEDS}

which are natives of Iceland or Africa, Siberia or Australia, Alaska or Mexico, introducing many species to a climate quite different from their original environment. As a consequence we are compelled to treat varied species in a different manner, so as to induce them to live and thrive under new and strange conditions. We find by experience that the seeds of some plants, coming from tropical regions, are too tender to stand the cold of our winters, and if subjected to it they perish, losing all power of germination.

It will, therefore, I think be a convenience to the growers of flowers if I give here these three lists: I. Annuals that should be planted in the fall ; 2. Annuals which may possibly be planted in the fall; and, 3. Annuals which should be planted only in the spring. As I have said elsewhere, this information applies to a very cold northern climate, and the farther south we go the more species will we be able to take from the second and third of these lists to add to the first.

I. Annuals that should be planted in the $F_{\text {ALL. }}$.

Abronia umbellata.

Alyssum maritimum, SWeEt Alyssum. 


\section{AND THE WILDERNESS BLOSSOMED}

Amarantbus Henderi.

“ tricolor, JOSEPH's COAT.

" caudatus, Love-Lies-BLEEdING.

Asperula orientalis.

Calendula officinalis, Pot MARIgold.

Centaurea cyanus, CoRnFlower.

Chrysanthemum coronarium, Summer Chrysanthemum,

or CRown Daisy.

Chrysanthemum segetum, CORN MARIGOLD.

Clarkia elegans.

Coreopsis tinctoria.

" Drummondii.

" coronata.

Delphinium Ajacis, Rocket Larkspur.

“ consolida, BRANCHED LARKSPUR.

Eschscholtzia Californica, California Poppy.

Helianthus annuus, Sunflower.

“ argapbyllus, Silver-Leaved Sunflower.

Iberis umbellata, CANDYTUET.

" amara, Rocket Candytuft.

Latbyrus odoratus, SWeEt PEA.

Layia elegans.

Linum grandiflorum, RED or SCARLET FlaX.

Matricaria inodora plenissima (Cbrysanthemum inodorum).

Nicotiana alata.

Papaver Rheas, CoRn Poppy of Europe.

" somniferum, OPIUM POPPY.

“ pavonium, Peacock Poppy.

“ glaucum, TUliP POPPY.

Portulaca grandifora, Rose Moss.

Salpiglossis sinuata. 


\section{SEEDS}

2. Annuals which may possibly be planted IN THE FALL.

Bracbycome iberidifolia, Swan River DaIsy.

Centaurea moschata, Sweet Sultan.

Diantbus Chinensis, China Pinks.

Godetia grandiflora.

Schizanthus pinnatus.

3. Annuals which should be planted only IN THE SPRING.

Callistephus hortensis, China Aster.

Cheirantbus Cheiri, W ALLF LOWER.

Chrysanthemum carinatum, TRICOLOR CRYSAnThemum.

Cosmos bipinnatus.

Gaillardia pulcbella.

Gypsophilla elegans.

Ipomeea purpurea, MoRning Glory.

Matthiola annua, Ten-Weeks Stock.

“ sinuata, INTERMEDIATE STOCK.

Mirabilis Falapa, Four o'clock, or Marvel of Peru.

Phlox Drummondii.

Reseda odorata, Mignonette.

Rhodanthe maculata, Everlasting.

Rudbeckia bicolor, ANNuAl CONE-Flower.

Tagetes erecta, African Marigold.

" patula, French Marigold.

“ signata, DWARF MARIgold.

Tropacolum majus, Climbing, or Tom Thumb NasturTIUM. 


\section{AND THE WILDERNESS BLOSSOMED}

Tropaolum minus, Smaller, or Tom Pouce NasturTIUM.

Tropaolum Lobbianum, LoBB's NAstuRTIUM.

In planting flower seeds the first thing that has to be decided, of course, is the location of the bed. A flower that requires the bright sun will fail utterly if planted in the shade. A preacher once was telling his hearers that all men have special capacities, and therefore special duties, and that they never could develop properly if they refused to do that for which they were best fitted, and illustrated the idea by saying that that beautiful flower, the fuchsia, required a shady spot and would not thrive in the bright sunshine. While greeting the members of his congregation after service, one good woman warmed his heart by taking his hand in hers and saying with moistened eyes, "Oh, Doctor, you do not know how I enjoyed your sermon! I never knew before what was the matter with my fuchsias."

Having selected the spot, the soil is the next consideration, and it must be adapted to the particular flower you wish to grow. I have attempted to give some instructions on this point when considering the different species. When none are given, it may be understood that the plants do 


\section{SEEDS}

well in full sunlight or partial shade, and that the best soil for them is a moderately rich loam.

I prefer to plant the seeds of all annuals where the flowers are to bloom. Some species cannot be transplanted at all, and it is injurious to all of them, as it takes most plants some days or even a couple of weeks to recover and get well rooted once more. Having prepared the bed, I sow very small seed, such as the Poppy, broad-cast, and then press the earth down with a board or the hand. A convenient board can be made for this work very easily by any one moderately skilled in carpentry. Take a half-inch pine board, about eighteen inches long by nine wide, and cut the corners off smoothly, so that it takes the form of an ellipse. On the centre of one side screw a wooden handle, and your "firmer" is ready. With seeds a little larger than the poppy, such as annual Larkspur or Escbscboltzia, after casting them evenly upon the bed, I go over the whole with the back of the rake, gently pulling a little earth over the seeds, and then pressing the whole down. Larger seeds still must be planted in drills, but caution must be exercised so as not to plant too deeply. More good seeds fail to germinate from this cause, 


\section{AND THE WILDERNESS BLOSSOMED}

probably, than from any other. A good general rule is to plant a seed no deeper than three times its diameter, and in following this rule, you will find that the lightest touch of the finger upon the soil in making the drill is sufficient for all but the largest seeds. Of course there are exceptions to this rule, and these I have pointed out under the different species. Thus the Nasturtium should be in the ground an inch, and the Sweet Pea fully five or six inches.

Every lover of flowers should gather the seeds from his own plants, whenever possible. Only by so doing can he learn the life history of his plants, and only thus can he get the best seeds. The best seeds are those from the choicest flowers on the sturdiest plants, and such should be marked when in bloom. Suitable tags are easily made, or they can be bought ready wired at the seedstores, for about $\$ 1.50$ a thousand. I do not use an indelible pencil for this work, but simply ordinary lead, which will be decipherable for the brief time it is exposed to the weather, and later the marks can easily be removed with a simple piece of rubber, and thus the tag can be used again and 


\section{SEEDS}

again. If the plants in a bed are all of the same variety and color, and you wish only to mark choice blossoms, a bit of colored worsted tied about the stem will serve all the purposes of a tag.

When you come to gather your seeds, you will need a quantity of paper bags of at least three sizes, small, medium, and large. Bags are made for this particular purpose without any gum on the flap. Do not buy the envelopes made for holding coins, for they are sometimes not thoroughly tight, and are apt to come apart if the seeds are slightly damp.

When you have a number of varieties of seeds to collect which you wish to keep separate, and can expect to get but a small quantity of each, you will find it convenient to use these envelopes for the seed-pods. Always mark the name on the envelope before you drop in the first pod, and then you will not be trying to remember what particular plant it came from. Where you have larger quantities to collect of a particular flower, small tin boxes about five inches long, three broad, and two deep, will be found useful. Such boxes - which should have hinged lids, by the way - can be bought for a trifle, or you can use the tin boxes which once contained tobacco 


\section{AND THE WILDERNESS BLOSSOMED}

or cigarettes. A collection of the ordinary tin cracker-boxes, in different sizes; you will often find useful. Here, too, remember to mark your seeds promptly. Write the name on a slip of paper, and always drop it into the box before you put a pod therein.

The best seeds of course are also those which are fully ripe. You will notice when the capsule has turned brown, and is just beginning to crack open, and this is the proper time to secure your seed. Taken earlier the seeds are not yet thoroughly dry, or even not quite ripe, and unless given sunshine and fresh air are apt to mould and prove worthless. If you delay too long, you will find in many cases that the seeds are nearly or quite gone, and that you are gathering only empty pods. The best time to gather seeds is probably soon after a period of cloudy weather, when the sun has but just dried the pods off sufficiently, for then you will find many pods full of seed. You cannot easily dislodge small seeds from a damp pod, but when the pods are thoroughly dry you can shake them out with little trouble, and without the labor of dividing or crushing each individual pod. 


\section{SEEDS}

To separate the seeds from the hulls and chaff, you will need sieves of various sizes. I bought, for a trifle, small pieces of woven wire cloth of ten different sizes, from one eighth of an inch mesh to the finest, and had a tinsmith remove the bottoms from as many old tin tobacco-boxes and substitute therefor the wire cloth. The hinged lids should be allowed to remain upon these boxes, as you will then be able to give the pods a good shaking to dislodge the seed. I numbered each box in rotation from the finest mesh to the coarsest. It may be necessary to pass the seeds through several sieves to clean them satisfactorily. First use one so large that all the seeds will pass through it, and thus get rid of the hulls and larger particles of chaff, and then use one so small that none of the seeds will go through, and the smaller waste will disappear. You should have at hand a good magnifying glass, that you may examine your seeds from time to time and become familiar with their appearance. By its use you will quickly learn to identify the perfect seed from the imperfect, or from the powdered bits of the hull. Choice seeds I put through the sieves again and again, getting thereby possibly three grades of 


\section{AND THE WILDERNESS BLOSSOMED}

large, medium, and small seeds, all clean and all capable of germinating, but the larger giving promise of the better flowers, and these latter only do I use on my beds. With some seeds sieving alone will not serve to separate them from the chaff. This is the case with annual Coreopsis amongst others, and here, having cleaned the seed as far as possible with the sieves, I place them in a shallow tin box and, blowing gently on the mass, easily dislodge the lighter chaff. This chaff, of course, does no real harm to the seeds, except that if kept for a time the chaff is more apt to gather moisture, spongelike, and thus prove injurious, and also if you allow the chaff to remain it is quite possible that one portion of your bed may be sown with chaff alone.

You will need a small brush to clean out your boxes and sieves; an ordinary flat paint brush, about three-fourths of an inch broad, will serve the purpose. Use it freely and carefully to prevent your seed getting mixed.

When your seeds are cleaned, put them in the envelopes provided, marking them distinctly with the name of the species, and its shape and color, if in any way peculiar, together with the 256 


\section{SEEDS}

date of gathering. Seeds kept over winter should be placed in their envelopes in small wooden cases rather than in metal boxes. They must be kept perfectly dry, and moisture is apt to congeal at times on tin boxes, and thus possibly injure the seeds. The box should have several wrappings of paper about it, to protect the seeds from extreme heat or cold, and the whole should then be stored away for the winter in a dry, cool place. Much heat will dry out the seeds with comparative rapidity and lessen materially the period during which they will retain the power of germinating. On the other hand intense cold will freeze the life out of the seeds of tender annuals, and many varieties, subjected to a temperature of zero, are thereby rendered absolutely worthless.

I have thus urged you to gather your own seeds, not because seeds cannot be bought, but because the seeds you gather and care for are far better than any you can buy. It is reasonable to presume, and my personal experience confirms it, that seeds raised in a particular region naturally do better there than those coming from a distance. Thus I found that poppy seeds which were apparently perfectly good if sown in the spring, 


\section{AND THE WILDERNESS BLOSSOMED}

would fail to survive the winter if planted in the fall. It took me, for instance, several years to get a race of Tulip Poppies that would bloom satisfactorily from seed planted in the fall. I have planted in the fall a thousand poppy seeds which came from a distance, and had but a beggarly dozen of plants the next season, yet apparently all of the seeds I afterwards gathered from these plants survived the following winter and germinated in the spring. This is not an exceptional instance, but has happened over and over again in my experience, and with almost every species of hardy annual I have raised.

There is, however, another reason why your own seeds will be the better. They are fresh! Some seeds, of course, retain their power of germination for a long time, but all seeds deteriorate to a greater or less degree for every day they are kept. I told you above, that you should mark on your packages of seeds the year in which they were gathered. Even when I wrote that line I deemed it an unnecessary detail, for I believed every amateur seed-grower would do this instinctively; as in his eyes the date would be almost as important as the name. Yet I know of but one seedsman in this country who makes even a pre- 


\section{SEEDS}

tence of giving a date for his seed, and he simply says, "All the seeds I offer are of the growth of 1899 ." There may be others who make such a declaration, but if so I have no knowledge of them. That old seeds are sold, and that they are often entirely worthless, there is no reason whatever to doubt. As I said before, the period that it takes to render a seed worthless varies materially. One variety of seed may remain comparatively good for years, while another is useless in a few weeks. Take the perennial Phlox paniculata, or decussata, for instance. I bought the seeds of this plant year after year, first by the package and then by the ounce, and planted them carefully, and yet not one seed ever germinated. Why I failed I found out later, when I learned that one cannot expect these seeds to germinate at all, unless planted almost immediately after becoming ripe, that is, during the fall they were produced. Do the seedsmen tell you this? By no means, and yet they sell you the seeds knowing them to be months, or possibly even years old, and presumably knowing, also, that they are worthless. Is this a harsh statement? It may be so, but it is not more so than that which the members of the 


\section{AND THE WILDERNESS BLOSSOMED}

trade say of themselves, or rather of each other. One of the largest growers in the country has for his motto the astounding words, "Blank's Seeds Grow!" It is on every one of his catalogues, on all public advertisements, on circulars, on his letter-headings, and in great letters it is painted on the walls of his warehouse. Think of what this implies! It can mean nothing at all unless it be true that the seeds usually sold, or at least frequently sold, by the trade are known to be incapable of germinating. What would be thought of a man who advertised “ Blank's Lamps can be Lit;" or what would be said of Brown if he were to advertise that his "Shoes can be worn," or of the furniture man who should announce that his "Beds can be Slept in," or of another who should declare that "Uwanta Biscuits can be eaten"? Would not such advertising be deemed absurd, simply because it is generally recognized that all lamps can be lit, shoes worn, beds slept in, and biscuits eaten? But in the seed business the converse must be the case if such words prove to be good advertising; yet why do you buy seeds if not with the expectation and belief that they will grow into plants and produce flowers, vegetables, or fruit? 


\section{SEEDS}

Now seedsmen are by no means modest in extolling the excellence of their wares, but use an extravagance of phrase in commending their goods, such as is only indulged in by the advertiser of a circus. They omit one essential thing, however, the absence of which makes all other claims worthless, for they give you no assurance that the seeds they sell will reproduce their kind. Here is what one of the largest dealers in America has to say on this point:

"While we exercise the greatest care to have all Seeds, Plants, and Bulbs pure and reliable, we do not give any warranty, express or implied. If the purchaser does not accept the goods on these conditions, they must be returned at once, and the money that has been paid for same will be refunded."

Here is what another leading firm has to say :

"We wish it to be distinctly understood that although we continue to take all possible pains to supply only New, Genuine, and Unadulterated Seeds, we still give no warranty, express or implied, as to description, quality, productiveness, or any other matter of any of the Seeds, Plants, or Bulbs we send out, and will not be in any way responsible for the crop. Every order received for articles named in this Catalogue will be executed on these conditions only." 


\section{AND THE WILDERNESS BLOSSOMED}

Of course it would be difficult to make language stronger than this, and what does it mean? It means that if I send these gentlemen $\$ 2.50$ for a dozen choice Gladiolus bulbs, and they think best to send me common bulbs or even plain ordinary onions in their place, under the terms of the sale I can have no redress whatever.

These seedsmen may, and do, make the most extravagant claims for their goods, yet they tell you at the same time that they will not and do net warrant one single word of it to be true. You are to understand, also, that these terms are not mere matters of form. I ordered from a reputable house an ounce of the seed of the early summer-blooming Cosmos, and the package which they forwarded to me, to the best of my knowledge, did not contain a single seed of the variety I had paid for. All were of the common, cheaper, lateblooming variety, absolutely worthless to me. I reported the matter to the dealers, but they have never offered to return the money I had paid to them.

It is only fair to say that all seedsmen do not attempt to run their business on such extraordinary terms. Here is what one grower says: "We guarantee that all seeds are First-Class, True, and 


\section{SEEDS}

Pure, and of strong germinating power in so far that should any prove otherwise, we will re-fill the order free, or refund the price paid." This is not an unfair offer. Another says nothing at all about a warranty, but declares that his seeds are fresh, of the finest strain, the best quality, and can be depended upon to grow and to produce the finest flowers, and he promises that "if mistakes occur they will be cheerfully corrected." There may be others offering terms as just as these to their customers, but, unfortunately, I know of but few.

When a seedsman acknowledges no responsibility whatever for his statements, it makes very little difference what he says or leaves unsaid, for by his own declarations his assertions are unworthy of consideration. From those, however, who are willing to be bound in some degree at least by their public statements, seed-buyers have, I think, a right to ask of them further information upon certain other points. If a dealer states that all of his seeds are the growth of a particular year, that covers the point of freshness fully, but in many cases this is not possible, nor indeed is it necessary, as many seeds several years old may still be considered fresh and good. It would be 


\section{AND THE WILDERNESS BLOSSOMED}

only just, however, for the dealer to do for his customers what he doubtless does for himself, that is, mark the date of growth upon the package. This is easily done, and the buyer would then know just what he was getting as far as freshness was concerned. Another serious difficulty in the matter of seeds refers to the question of quantity. When one buys seeds by weight, he knows how much he will get for the price asked, but when he buys a "package" the amount he will get is entirely unknown. I once paid fifty cents for a package of carnation seeds, and found upon opening it that I had received just exactly six seeds. On remonstrating with the dealer I was told that I had received one seed more than I was entitled to, five being the limit for that special variety. Perhaps it was just as well that I did n't get any more of these seeds, for none of the six germinated; but why did not the dealer tell his customers that there were but five seeds in such a package? Was it because he believed that if he did so people would not buy these packages? I can conceive of no other reason for the concealment. Some dealers do state the number of seeds in a package when the seeds are large, and others, besides offering seeds by 


\section{SEEDS}

the ounce, also put up packages containing 1000 seeds; and if this is possible why is it not equally possible to sell still smaller definite quantities, or why should not each package contain 100 or 50 seeds, or any number, so that a "package" might become a definite or known quantity? In case of inexpensive seeds, a package might contain a double measure, and more costly varieties could be put up in half measures, or any fraction you choose, stating the fact plainly in the catalogue and upon the package. It makes but little difference what the standard may be, but it is of the first importance that there should be some standard. Another important point which should also be stated, is the place from whence the seeds come. Now, when one buys seed he has no means of knowing whether it was grown in Europe or America, in Florida or in Maine, in 1900 or before the war.

There is much room for improvement in the ordinary seedsman's catalogue. There is some attempt at classification, to be sure, but almost invariably annuals, biennials, perennials, and vines are still jumbled together in a single section, and the compiler moreover often omits to note whether a plant is annual, biennial, or perennial, 265 


\section{AND THE WILDERNESS BLOSSOMED}

and whether hardy, half hardy, or tender. Every plant should be entered under its proper botanical name, with cross references from the common name. I know of but two seedsmen who invariably do this. One enters a flower always as Candytuft, while in another's catalogue you must look for it under the head of Iberis, and it is common also to see the perennial varieties of some species entered under the botanical name, while the annuals are found under the common title in the same catalogue. I have three catalogues before me now in which one flower is entered as Mirabilis, another has it headed Fouro'clock, while in the third you will find it under the head of Marvel of Peru.

The description should be written in plain English, and not always in the superlative degree. The compiler having exhausted all his adjectives of praise on the ordinary or even inferior flowers has nothing left with which to describe plants of real merit. There is entirely too much indiscriminate praise given to all sorts of inferior plants, and when a flower is too insignificant to excite the enthusiasm of the cataloguer he generally says "it is stately," if tall, or if dwarf, he falls back on the assertion 


\section{SEEDS}

that "it has a neat habit of growth." In this they remind me of the Professor who when shown by a proud mother a baby far from beautiful, exclaimed with apparent rapture, "What an alert face!"

In most of the seed catalogues there is a section devoted to novelties, generally printed upon a vivid-colored paper, probably to keep pace with the flaming descriptions. In my experience, not one in ten of these so-called novelties is worth planting at all, and not one in ten of these ten ever produces a flower that bears a near resemblance to the description. Of course, now and then, a new variety of real merit is introduced, and naturally it first appears on these pages, but the prizes are so few and the blanks so many that it is not worth while to risk money on this sort of gambling. The seedsmen are straining every nerve to produce something new and good in flowers or vegetables, for in the event of success the profits are large, and the effort is in every way commendable, but, failing to obtain a plant of real merit, the temptation to invent one is strong. Every one knows that in certain localities and under exceptionable conditions old and well-known flowers have been 


\section{AND THE WILDERNESS BLOSSOMED}

known to reach marvellous proportions in the size of both plants and flowers, and in the profusion of the bloom. The heliotrope, with its dwarf plants and small blossoms, has been carried to California, where it grows so large as to be almost a tree; but would it be fair to sell us the seeds on a description based upon its appearance there, accompanied by a photograph showing its colossal size and profusion of bloom? Yet, if it were a comparatively new or unknown plant, this is exactly what one might expect to see done. In referring to this matter one of the oldest seed houses in America, says :

"It really seems as if the creature, man, was as anxious to be deceived in seeds as in quack medicines, for we do not hesitate to declare, upon our reputation as seedsmen of repute, that nine-tenths of the so-called new sorts advertised at high prices are, so far as merit goes, rank humbugs, and it is time the public were told so. One tires of reading the adjectives of superlative degree used in describing them; and one becomes still more worn to find, after months of watching and waiting, that the highly extolled are no better than old familiar sorts."

Had I the inclination I could not write anything harsher than this. All readers of -seed catalogues have been impressed by the " adjec268 


\section{SEEDS}

tives of superlative degree" to which this writer refers in the annually recurring lists of novelties; and to give an example of it, let us suppose that some genius of a grower, failing to produce his longed-for novelty, and finding his beds burdened with an overstock of sorrel, should in a moment of inspiration conceive of the idea of disposing of his surplus weeds to the always gullible buyers of seeds and plants. In attempting to ascertain how an artist in this class of advertising would be likely to describe such a novelty, we need not call upon the imagination at all, for the seedsmen have done the work for us, and every sentence and phrase in the following description is taken from the catalogues of certain well-known dealers who are most careful to declare that they give no warranty, express or implied, as to their own descriptions. Let me note, in explanation, that the proper botanical name for sorrel is Rumex acetosella, so that there is actually no deception.

A Grand New Rumex.

Frau Corie Marelli. (Rumex acetosella, var. Boddlepopsteri.)

Without doubt the most sensational new plant introduced for many years, and entirely 269 


\section{AND THE WILDERNESS BLOSSOMED}

distinct from anything heretofore offered. It has been produced by Pan Boddlepopsteritch, the famous Polish Rumexist, who for this striking novelty was awarded a first-class certificate by the floral committee of the Royal Perfidical Society at Oohiskeywitch. This is undoubtedly the greatest gain in hardy perennials yet introduced. It is a strong robust grower, the lance-oblong or halbert shaped leaves forming bold clumps of the most brilliant green, making the plant a most striking object in any well-kept lawn. The remarkable floriferousness and the great size of the spikes of flowers compared to the delicacy of the stem gives the whole plant a lightness, grace, and elegance difficult to describe, and makes it certain that it is destined sooner or later to find its way into every garden. Beginning to bear its graceful and airy heads of flowers early in June, the stems are still completely smothered with soft rosy pink blossoms when the frosts of the coming winter have laid prostrate all less hardy plants. A bed containing about 5000 plants of this variety eclipsed anything we ever saw. We can convey but a faint idea of the beauty and distinct warm coloring of this splendid 


\section{SEEDS}

acquisition. We have succeeded in working up

a large stock which enables us to offer it at a popular price.

Good young plants, 50 cents each, $\$ 5.00$ per dozen. 


\section{POSTSCRIPT}

"Deliver all with charity."

\section{I}

WONDER whether I have not been making myself a little unpleasant about our flowers and their seeds. Possibly I have been thinking only of the woman who has saved a trifle out of the market-money to buy her few seeds, and for her self-denial has received little or maybe nothing.

The story is told of an American Bishop who had been staying at an English country house; and left one morning in company with a young gentleman who had also been a visitor at the same place. When they alighted at the station, the Bishop hurried to the train, while his companion searched in vain for his gun, which it appeared had been left behind. He abused the servant roundly, using language fitted only for the ceremony of excommunication, and at the last moment leaped on board the train to find himself face to face with the Bishop. He colored 


\section{POSTSCRIPT}

slightly as he said, "I beg your pardon, my lord" (even Yankee bishops are lords in England), " for my language, but I am a plain-spoken man and always call a spade a spade."

"Indeed," said the Bishop, "I 'm surprised at that. From your conversation just now, I might have supposed that you would call it a $d-d$ old shovel."

Have I been calling honest spades excommunicated old shovels? If I have, then let me beg pardon of the spades. Flowers are too beautiful to quarrel over, but let us instead all cordially join hands, and try to make them bloom ever more beautifully, more bountifully, and where they never bloomed before.

When I first came to Insley very few flowers were to be seen thereabouts. Only a geranium or two in a window testified to the love of flowers by the inmates; but as the years have passed the flowers have increased, and now dot most of the lawns about the dwellings in the village, and near the farmhouses by the lake. In this I have helped where and when I could, and little packages of seeds found their way to those who longed for them. Do not let this be deemed a hint to others to turn to the island for seeds, I8 


\section{AND THE WILDERNESS BLOSSOMED}

for I have no wish to injure the business of the seedsmen, but only to make it better for the flower-lovers, and, in the end, ever so much better for the seedsmen themselves.

Every year very many people who are strangers to me land upon the island, and wander about its shady walks or down upon the terraces. Very many others who might have done so have for some reason refrained. Those who came gave me pleasure, because they found pleasure in coming; while those who stayed away disappointed me, for I could not but think that either they did not love flowers, or else believed that I would not willingly have them look upon the flowers that we both loved.

From early spring till late fall I am very busy, planting, transplanting, weeding, or gathering seed, so that it is not always or often easy for me to stop and try to entertain chance visitors, but let it be understood that no one is ever entertained on the island, though all are welcome to come, and see, and walk, and enjoy, aye! and to pluck the blossoms also, if they will but be kind and tender to the plants. 


\section{INDEX $^{1}$}

Abronia umbellata, 243, 247. Achillea ptarmica, 176. Agrostemma coronaria, 164 . ALKANET, 78.

AlleghenY Hollyhock, 143. Alsike Clover, 27.

Althea rosea, $142-145$.

Alyssum, 179, 225, 226, 232, 233, 236.

Benthami compactum, 225. compactum erectum, 225. procumbens, 225. maritimum, 225, 226, 247. perennial, 179.

Amaranthus caudatus, 243, 248. Henderi, 242, 248. tricolor, 242, 248.

Amberboa mosihata, 209, 210. odorata, 209, 210.

AMERICAN IRIS, I65, 166.

Ampelopsis quinquefolia, 159, 165. Anchusa Italica, 178.

ANNUALS, I89-245.

Annuals, only in the Spring, 249, 250.

planted in the Fall, 247, 248. Anthemis chamomilla flor plena, 212.

coronaria, 239.

tinctoria, 180 .

Anthericum liliastrum, I76.

Aquilegia, 134, 135, 236.

Arabis albida, 176 .
Arbor Vitæ, 29.

Ash, Mountain, 28.

Asperula azurea setosa, 238.

odorata, 186,187 .

orientalis, 238, 248.

Aster, China, 208, 209.

BABY'S BREATH, I66, I67.

BACHELOR'S BUTTON, 2I7-220.

Balsam Fir, 29.

Baptisia australis, 178 .

Beds for flowers, $250,25 \mathrm{I}$.

BEE BALM, 152.

LARKSPUR, I4I.

Bellis perennis, $169,170$.

Best seeds, 252, 254, 257, 258.

BIENNIALS, PERENNIALS AND, I3I-I88.

Birch trees, 24, 25, 27, 28.

Birds, 89-i I 9.

Books on, 70 .

BIRTHROOT, I84, 185 .

Black Duck, IOI.

BLANKET FlOWER, I32, 133 .

BLEEDING HEART, I60, I6I.

Bluebottle, 217.

BLUET, 217.

Bob White, II 2, II 3 .

Bocconia cordata, 174 . Japonica, I74.

Books, Children's, 7I, 72. criticisms on, $78-88$.

1 Chapter headings are printed in CAPITALS, the common names of flowers in SMALL CAPITALS, the botanical names in italics, and all other references in ordinary type. 


\section{INDEX}

Books for a Summer Library, 6r88.

First Choice, 63-68.

Second Choice, 75-77.

of Reference, 72,73 .

Out-of-Door, 69, 70 .

Boxes for seeds, 255, 256.

Brachycome iberidifolia, $238,249$.

BRoMPTON STOCK, 233.

Brush for seeds, 256.

BUNCHBERRY, 185 .

Bush EschscholtziA, 224.

Butterfly PeA, I81, I8z.

Calendula officinalis, 220, 221, 248 .

CALIFornia Poppy, 223-225, 248.

Calliopsis, 2II.

Callirhoe involucrata, I75, 177.

Callistephus Chinensis, 208, 209.

horlensis, 208, 209, 249.

Campanula calycanthema, I40.

carpatica, I 53, 154.

glomerata, 154 .

grandiflorum, 173 .

latifolia, 154,155 .

Medium, 140.

pyramidalis, 154 .

Campanulas treated as biennials, 154 .

CandYTUfT, 226, 227, 233, 248. perennial, 179 .

Canterbury Bell, i4o.

CARNation, 182,183 .

Carnation-Flowered Poppy, 190, 195.

Carpathian Harebell, I53, I 54 .

Cedar trees, 29.

Ceilings, 7,8 .

Centaurea chamaleon, 209. cyanus, 21 7-220, 248.

imperialis, 209.

Margarita, 209.

montana, 178, 179.
Centaurea moschata, 209, $210,249$. suaveolens, 209.

Centrosema grandiflora, 181, 182 .

Chaff in seeds, $255,256$.

ChaMomile, I80.

Cheiranthus cheiri, 235, 249.

Chickadee, 98.

Chickens, II4-I 16.

Children's Library, 7 I.

Chimney Campanula, 154.

Chimney-Swift, 96, 97.

ChINA Aster, 208, $209,249$.

PINK, 207, 208, 249.

Chinese PaenY, 172.

Chipping Sparrow, 100.

Chrysanthemum Burridgeanum, 240.

carinatum, 240, 249 .

coccineum, $153, \mathrm{I} 67$.

coronarium, 239, 248.

Dunnetti, 240.

inodorum plenissimum, 213, 248.

lacustre, 163, 164 .

latifolizm, 163.

maximusm, 163, 164 .

segetum, 240, 248.

SUMMER, 239, 248.

TRICOLOR, 240, 249.

uliginosum, 163.

Clarkia elegans, 244, 245, 248.

Classics, 73.

Cleome grandis, 245.

Climate of Maine, 120, I2I.

COLUMBINE, I34, I 35 .

CONE-FLOWER, I73, 174, 240, 249.

Convallaria majalis, 149 .

Convolvulus majus, 238. purpureus, 238.

Coreopsis, 136, I69, 21 I, 212.

atropurpurea, $2 \mathbf{1 2}$.

atrosanguinea, 212 .

coronata, $212,248$. 


\section{INDEX}

Coreopsis Drummondii, $212,248$.

GOLOEN WAVE, 212.

lanceolata, 136, 169 .

nigra speciosa, 21 2 .

tinctoria, $2 \mathrm{II}, 212,248$.

CORN-BOTTLE, 217.

CORNFLOWER, $217-220,248$.

perennial, $178,179$.

Corn Marigold, 240, 248.

CORN POPPY, T94-198, 248.

Cornel, DWARF, 185 .

Cornus Canadensis, 185 .

Cosmos bipinnatzs, 210, 2 I I, 249.

Covent Garden Gypsophilla, 243.

Criticisms on Books, 78-88.

Crown DaIsY, 239, 248.

CRUCIFER/E, 233.

Cupid Sweet Pea, 203.

Daisy, Crown, 239, 248.

ENGLISH, I69, 170.

GIANT, 163.

SWAN RIVER, 238, 249.

Date on seed packages, 257-260.

Day LiLY, $158,159$.

Delphinium Ajacis, 21 5, 248.

candelabrum, $2 \mathrm{I} 5$.

cardinale, I4I.

cashmerianum, I4I.

cheilanthum, $\mathbf{r} 4 \mathrm{I}$.

Chinense, I4I.

consolida, $215,248$.

elatizes, I41.

elatum, i4I.

formosum, $\mathbf{1 4}$.

grandiflorum, I4I.

Imperialis, 215.

majzes, 215 .

minus, 215.

nudicaule, 14I, 142.

Sinense, I41.

Zalil, 141 .
Dianthus barbatus, 133, 134 .

Chinensis, 207, 208, 249.

Heddervigii, 207, 208.

plumarius, $155,156$.

Sinensis, 207, 208.

Dicentra spectabilis, $160, \mathrm{I} 61$.

Dielytra, 16r.

Digitalis purpacrea, I $37^{-1} 39$.

DOCK WEED, r7o.

DOGWOOD, DWARF, 185 .

Duck, Wounded wild, I7 I, 172.

Ducks, Tame, ti 6.

DWARF CORNeL, 185.

DOGWOOD, 185 .

Elm trees, 28.

EMPRESS CANDYTUFT, 227.

ENGLISH DAISY, 169, 170.

Pheasant, I08-1 i2.

Scarlet Poppy, 194, 196.

Envelopes for seeds, 256,257 .

Eschscholtzia aurantiaca, 224.

Busi, 224.

Californica, 223-225, 248.

Crocea, 223, 224 .

alba, 224.

for plena, 224.

mandarin, 224.

rosed, 224 .

Douglasii, 224.

GOLDEN WEST, 224.

maritima, 224.

EVENING PRIMROSE, I80.

EverLasting, 244, 249.

Fall planting, Seeds for, 247,248 .

FALSE INDIGO, I78.

FEVERFEW, 153 .

Fir, Balsam, 29, 3I.

Fireplaces, IO-I2.

Fish, Books on, 70 .

FLAX, Perennial, $\mathrm{I} \epsilon_{7}, \mathrm{I} 68$.

RED or SCARLET, $237,248$.

Descriptions of Flowers, 266, 267. $\mid$ FLEUR-DE-LIS, I66. 


\section{INDEX}

FLOWER-BEDS, I 20-I 30 .

FORGET-ME-NOT, 145, 146, I69.

FOUR-O'CLOCK, 242, 249.

FoXGLOVE, 137-I 39 .

FRAGRANT BaLM, I 52 .

Fresh seeds, 258-260.

Funkia, 159.

Gaillardia aristata, 132. grandiflora superba, I32, I33. picta, 24I.

Lorenziana, 24r. pulchella, 241, 249.

Galium trifolium, 186, 187 .

Garden, Books on the, 69 .

GARDEN PINK, 155, 156 .

Gathering seeds, 253, 254 .

Geese, Wild, I70, I7 I.

German IRIS, I66.

Germinating power of seeds, $25^{8-}$ 260.

Giant DaIsy, I63.

GLobe Amaranth, 217 .

Godetia grandiflora, 243, 244, 249. Whitneyi, 243.

Golden Marguerite, 180 .

WEST EschscholTZIA, 224.

Gomphrena globosa, 21 \%.

Grass seeds, 26, 2\%.

Guinea Fowl, I 6 .

Gypsophilla elegans, 243, 249. paniculata, I66, I67, 243.

Hackmatack, 3 .

Hallways, 15.

HaRdy Garden Carnation, 182,183 .

"Hardy Heliotrope," 179.

Hardy seeds, 257,258 .

Helenium autumnale, I74.

Bolanderi, 174.

Hoopesiz, 174.

Helianthus annutus, 229, 248 argophyllizs, 229, 248 .
Helianthus Californicus, 230, 23I. cucumerifolizus, 229.

debilis, 229.

globosus fistulosus, 230.

macrophyllus giganteus, 230.

multiflorus, 230.

nanus flor pleno, 230.

sulphurus, 230 .

Perutrianzes, 230 .

variegatus, 230.

Perennial, I83.

"Heltotrope, Hardy," I79.

Hemerocallis fava, I 58, 159 .

fulva, 159.

middendorfii, 159 .

minor, 159 .

Hibiscus Africantes, 245.

HoLLYHOCK, I 42-I 45 .

HONESTY, I 8I.

HONEYSUCKLE, I 59.

HOOKER'S EARLY-FLOWERING

POPPY, 196, 197.

House-building, 6-9.

Humming Bird, 97.

Tberis amara var. coronaria, 226, 248.

perennial, 179.

umbellata, 226, 248.

ICELAND POPPY, I46-I 48.

IMPERIAL JAPANESE MORNING

GLORY, 239.

India PINKS, 207, 208.

INDIGO, FALSE, I78.

INTERMEDIATE STOCK, 233, 249.

IN THE BEGINNING, I-3I.

Ipomaa purpurrea, 238, 239, 249.

Iris Germanica, 166.

Kampferi, 166.

laevigata, $\mathrm{I} 66$.

psezudacorus, 166.

Virginica, 165, 166. 


\section{INDEX}

JACOB'S LADDER, I 78 .

JAPANESE HOLLYHOCK, I43.

IRIS, I 66.

MORNING GLORY, 239.

ROSE, I62.

JOSEPH'S COAT, 242, 248.

KaISER-BLUMEN, 217.

Keeping seeds, 257.

Kentucky Blue-grass, 27.

Kingbird, 100 .

Kingfisher, 98-100.

KNAPWEed, MoUntain, I78, I79.

LAMP FLOWER, 207. Larch, American, 30.

LARKSPUR, BEE, 141 .

BRANCHING, $215,248$.

EMPEROR, 2I 5.

Perennial, 14I, I42.

ROCKET, 2I 5, 248.

Lathyrus latifolius, 164, 165 . odoratus, 200-203, 248.

Lawns, 24-26.

Layia elegans, 231, 248.

Leaf-mould, I 29, I 30 .

Library, Books for a Summer, 6I.

Lilium auratum, 156, 157 .

candidum, 158 .

croceum, 158.

longiflorum, 158.

speciosum, 158.

tenuifolium, I 57, I 58 .

tigrinum, 157 .

var. splendens, I 57

LILY-OF-THE-VALLEY, 149.

Linnea borealis, 183,184 .

Linum coccineum, 237.

grandiflorum, 237, 248.

narbonnense, 167,168 .

rubrum, 237 .

LobB's Nasturtium, 204-206, 250.
Location of Flower-beds, 250.

Lonicera Periclymenum, 159.

Loon, 102-104.

LOVE-LIES-BLEEDING, $243,248$.

Lunaria annua, 181 .

biennis, $78 \mathrm{r}$.

LUPIN, 168, 169 .

Lupinzus polyphyllus, 168, 169.

Lychnis celi-rosa, 164 .

coronaria, I64.

fulgens, 207.

grandiflora, 207.

Haageana, 207.

Machet's Perfection MignonETTE, 210.

MALLOW, I75.

Malva moschata, I60.

MAMMOTh FRINGED ALLEGHeNY HOLIYHOCK, I 43.

Maple trees, 28, 30.

MaRguerite, Golden, I80.

MARIGOLD, AFRICAN, 22I-223, 249.

CORN, 240, 248.

FRENCH, 221-223, 249.

POT, 220, 22I.

Marvel-of-PerU, 242, 249.

Matricaria inodora plenissima, 21221 5, 248.

Matthiola annua, 233, 234, 249.

incana, 233.

sinuata, 233, 249.

MAYWEED, 2I 2-2I5.

MEN OF MAINE, 32-60.

MignONETTE, 210, 249.

MINT, 187.

Mirabilis Jalapa, 242, 249.

Monarda didyma, 152,153 .

fistulosa, I52, I 53 .

MORNING GLORY, 239, 249.

Moss PINK, I 5 I.

Mountain Ash, 28.

Mountaln KNapweEd, 178, I79. 


\section{INDEX}

Mourning Bride, 24I.

MULLEIN LYCHNIS, 164. PINK, 164.

Musk Mallow, I6o.

MUSTARD Family, 233.

Myosotis alpestris, $345,146$.

palustris, 145, I46. semperflorens, 145 .

Rehsteineri, 146. syluatica, 145, I46.

Names of Plants, 265, 266.

NASTURTIUM, 204-207, 249, 250.

Nicotiana affinis, 23I.

alata, 231-233, 248.

Giant RED, 232.

Nightshade, Three-Leaved, 184,185 .

Novelties in Plants, 267-27I.

Enothera biennis, 180.

Old seeds, 258-26o.

Olive-backed Thrush, Ioo.

OPIUM POPPY, I89-194, 248.

Oriental Poppy, 148, I49.

OsWego TEA, I 52.

Out-of-Door Books, 69 .

Owls, 108 .

Packages of seeds, 264, 265.

Paonia albiflora, 172.

Moutan, 173.

officinalis, 172 .

peregrizza, I72.

PAOONY-FLOWERED PoPpy, 190.

PaINTed TrIlliUm, 185.

Pansy, I3I, 132.

Papaver bracteatum, 148.

glaucum, I98, 199, 248.

Hookeri, 196, 197 .

Murselli, 190 .

nudicaule, 146-148.

orientale, $148,149,168$.

PAONY-FLOWERED, 190.
Papaver pavonium, 198, 248.

Rhceas, 194-1 98, 248.

somniferum, 189-194, 248.

umbrosum, 197.

Paper bags for seeds, 256, 257.

Paridisea liliastrum, 176 .

Partridge, I05.

Peabody Bird, 94, 95.

PEA, Bu'tTeRfly, I8I, I8z.

PEACOCK POPPY, I98, 248.

Pea-fowl, II 7-I I 9 .

Pea, Perennial, I64, I65.

PEA, SWEET, 200-203, 248.

PEARL ACHIILEA, I 76.

STOCK, 234.

Perennial Flax, 167, 168.

PEA, I64, I65.

PERENNIALS AND BIEN-

NIALS, I $3^{\mathrm{I}-188 .}$

Pharbitis hispida, 239.

Pheasant, Io8-II2.

Phlox decussata, $\mathrm{I} 5 \mathrm{o}$.

Drummondii, 149, 216, 217, 249.

frondosa, $\mathrm{I} 5 \mathrm{I}$.

maculata, I 50, $15 \mathrm{I}$.

Nelsoni, I 5 I.

nivalis, $\mathrm{r} 5 \mathrm{I}$.

paniculata, I49-I 5 I.

reptans, I $5 \mathrm{I}, \mathrm{I} 52$.

stolonifera, I $5 \mathrm{I}$.

subulata, I 51, I 52.

suffraticosa, I 50 .

verna, I 5 I, 152 .

Pine trees, 24, 28, 3 I.

PrNK, China, 207, 208, 249.

GARDEN, I 55, I 56.

Her Majesty, 155 .

INDIA, 207, 208, 249.

Moss, 15 I.

SсотCH, I 55, I 56.

Place of growth of seeds, 257, $25^{8}$.

Plantain Lily, 159. 


\section{INDEX}

Plant names, 265, 266.

novelties, 267-27 I.

Planting seeds, 25r, 252.

Platycodon autumnale, 173. grandifiom, 173 . mariesii, 173 .

Plumbing, 20.

PluME Poppy; I74.

Polemonium caruleum, 178.

Polygala lutea, 217, 2 18.

Poppy, AMERICAN FLAG, IgI.

BLACK KNIGHT, IgI.

BRIDE, I92.

California, 223-225, 248.

Carnation-Flowered, igoI95.

CORN, I94-200, 248.

Crimson KInG, IgI.

DANEBROG, 192.

DANISH FlaG, 192.

EIDERDOWN, 190.

ElDoRADO, IgI.

EMPRESS OF CHINA, I92.

ENGLISH SCARLET, 196.

FaIRY Blush, 191.

Fayal, I93.

Firebrand, 191.

Giganteum, 193.

HOOKER'S EARLY FLOWERING, I96, 197 .

ICELAND, I46-I 48 .

IRRESISTIBLE, 196.

LADY-IN-WHITE, I9I.

LAVENDER BEAUTY, IgI.

MaId-OF-THE-MIST, 193 .

Majestic, I95, I96.

MIKADO, I9I.

OPIUM, I89-194, 248.

ORIENTAL, 148, I 49 .

Ortental Beauties, 193.

PFONY - FLOWERED, 190, I9I.

PEACOCK, 198, 248.

Plume, I74.
Poppy RanunCULUS-Flowered, 194, 195.

ROSY MORN, IgI.

ShIRLeY, 194-196.

SNow-Balt, rgr.

SNow-DRIFT, 190.

TULIP, I98, 248.

WHITE-SWAN, 190.

WILKS'S IMPROVED, 197.

Portulaca grandiflora, 235-237, 248.

POSTSCRIPT, 272-274.

Pot MARIGOLD, 220, 221, 248.

Primrose, Evening, i8o.

Prohibitory liquor laws in Maine, 38-43.

PyRamidal Stock, 234 .

Pyrethrum roseum, I53, I67.

uliginosum, 163 .

Quail, I I2, II 3 .

Quantity of seeds in a package, 264,265 .

QUEEN STOCK, 233.

RAGGED SAILOR, $2 \times 7$.

Ranunculus acris, 217 .

Ranunculus-flowered POPPy, I94, I95.

Red-breasted Nuthatch, Ioo.

Red-eyed Vireo, 100.

RED FlaX, 237, 248.

Redstart, 95.

Red-top grass, 27

Reference, Books of, 72, 73 .

Reseda odorata, $210,249$.

Rhodanthe maculata, 244, 249.

Ripe seeds, 254 .

Road-making, 25.

Robin, 89-94.

ROCK-CRESS, 176 .

ROCKET, 233 .

CAN DYTUFT, 226, 227, 248.

LARKSPUR, 21 5, 248. 


\section{INDEX}

Rosa lucida, 163.

rubiginosa, 162, 163.

rugosa, 162.

Rose Campion, I64.

Moss, 235, 248.

OF-HEAVEN, I64.

Roses, I6r- 63 .

Rudbeckia bicolor, I73, 240, 24I, 249.

Golden GLow, 173, 174.

laciniata, $173,174$.

Ruffed Grouse, I05-I08.

Rumex acetosella, 269-27I.

Salpiglossis sinuata, $203,248$.

Scabiosa atropurpurea, 24I, 242.

Caucasica, $\mathbf{1}_{3} 6$.

Scarlet Flax, $237,248$.

Scarlet Tanager, roo.

Schizanthus pinnatus, 244, 249.

Scotch Pink, I 55, I 56.

Second Choice of Books, 75-77.

SEEDS, 246-27I.

Seeds, Catalogues of, 265-267.

Cleaning, 255, 256.

Date of, 257-260.

Fresh, 256-26o.

Gathering, 253, 254 .

Keeping, 257.

of Novelties, 267-27I.

of the Poppy, I99, 200.

Place of growth of, 257, 258.

Planting of, $25 \mathrm{I}, 252$.

Quantity in a package of, 264 , 265.

Ripe, 254 .

Stale, 1 50, $259,260$.

The best, $252,254,257,258$.

Seedmen's terms of sale, $261-263$.

Servants, Household, 17-20.

Shelldrake, Io2.

SHIRLEY POPPY, 194-196.

Siberian Coral Lily, I 57, I 58.
Sieves for seeds, 255 .

SNEEZE WEED, 174 .

SNEEZEWORT, 176.

Soil for flower-beds, I 23-1 25.

SOME BIRDS, 89-119.

SORREL, 269-27r.

Sparrow, Chipping, roo.

White-throated, 94, 95 .

Specularia speculum, 245 .

SPEEDWELL, I78.

SPIDERWORT, I79, I80.

Spring planting, Seeds for, 249. 250.

Spruce trees, 24, 28, 29, 3 I.

Stairways, I 2-I 4.

Stakes for flowers, I 44 .

ST. BRUNo's LiLY, I 76.

Steeple Beliflower, I 54 .

STOCK, 233, 234, 249.

Storing seeds, 257.

Summer. Chry santhemum, 239 , 248.

SUNFlower, Annual, 229-23I, 248.

Giant Russian, 230.

Globe-of-Gold, 230.

Mammoth RUSSIAN, 230.

Perennial, I83.

STEI.LA, 230.

Sulphur GEM, 230.

Thousand-FLOWERED, 230.

SWAN RIVER DAISY, 238, 249.

SWEET BRIER Rose, I62, 163 .

Alyssum, 225, 226, 247.

PEA, 200-203, 248.

Scabious, 24I, 242.

Sultan, 209, 2 I0, 249.

WILLIAM, I 33 , I 34 .

WOODRUFF, I86, I87.

Tagetes erecta, 22 [-223, 249.

patula, 22 I, 222, 249.

nana, 222. 


\section{INDEX}

Tagetes signata, 221, 249.

pumila, 222.

Tags for flowers, 252, 253.

Tamarack, 30.

Tanacetum vulgare, 187, 188.

TANSY, $187,188$.

TEN-WeEkS STOCK, 233, 249.

Terraces for flowers, 125-I 27 .

THE VESTIBULE, 6I-88.

ThreE-LEAVED Nightshade, I84, I85.

Thrush, I00.

Time to gather seeds, 254.

ToKIO HOLLYHOCK, I43.

Tom Pouce Nasturtium, 204.

Thumb Nasturtium, 204207, 249.

Tradescantia Virginica, 179, 180.

Transplanting Flowers, $25 \mathrm{I}$.

TREE PAONY, 173.

Tree transplanting, 3O, 3I.

Trellis for Sweet Peas, zor.

Tricolor Chrysanthemum,

$240,249$.

Trillium, 184, 185 .

cernuum, 185 .

erectum, 185 .

erythrocarpum, 185 .

grandiflorum, 185 .

PAINTED, I 85.

Tropcoolum Lobbianum, 204, 250.

majus, 204, 249.

minus, 204, 250.

TUlip POPPY, I98, I99, 248.

TWIN-FLOWER, 183,184 .

Valeriana, 179.

Vegetables, 128, I 29.
VENUS' LOOKING-GLASS, 245.

Veronica spicata, I78.

VICTORIA ASTER, 208.

Viola odorata, I8I.

tricolor, 131,132 .

VIOLET, I8I.

VIRGINIA CREEPER, I 59, I65.

WAKE-ROBIN, I84, 185 .

WALLFLOWER, 233, 235, 249.

Warranty of seeds, 26I-263.

Water works, 20-24.

White Day LiLy, I 59 .

White-throated Sparrow, 94, 95.

WILD BERGAMOT, I 53 .

Wild Flowers, 183-185.

WILD ROSE, I63.

WILKES'S IMPROVED RHAEAS

POPPY, 197.

Willows, 30.

Windows, 9 .

WOODBINE, I 59, I60, I65.

WOOD-LiLY, I84, 185.

Woodpecker, I00.

Worthless seeds, I 50, 259, 260.

Yankees, 32.

YARROW, 176 .

YELLOW BACHELOR'S BUTTON, 218.

DAY LiLy, I 58, 159.

IRIS, I 66.

Yucca filamentosa, I8I.

Zinnia elegans, 227-229.

robusta plenissima, 228. 




